


\title{
DIELECTRIC RELAXATION IN CELLULOSE \\ CONTAINING SORBED VAPORS
}

\author{
A Thosis \\ by \\ Ruth Seidman, B.Sc.
}

Submitted to the Faculty of Graduate Studies and Research in partial fulfilment of the requirements for the Degree of Doctor of Philosophy.

MoGill University

April, 1953 


\section{ACKNOWLEDGMENTS}

The author wishes to record her profound gratitude to

Dr. S.G. Mason, who was always a source of inspiration and indispensable suggestions in his supervision of this work.

Dr. 0. Maass for his constant friendliness and interost.

Dr. H.G.I. Watson of the Department of Physics for calibra-

tion of oscillators.

Mr. G. Ensell of the National Research Council for construction of the dielectric cell.

Mr. H. Green for the fibre identification and Mr. V. Berzins for the fibre analysis, both of the Pulp and Paper Research Institute of Canada.

Others among the members of the staff and students in the dopartment who were always generous with thoir advice and criticism.

The Pulp and Paper Research Institute of Canada for financial assistance during the torm $1949-50$.

The National Research Council for a Bursary in 1948 - 49, a Studentship in $1950-51$ and Followship in $1951-52$. 


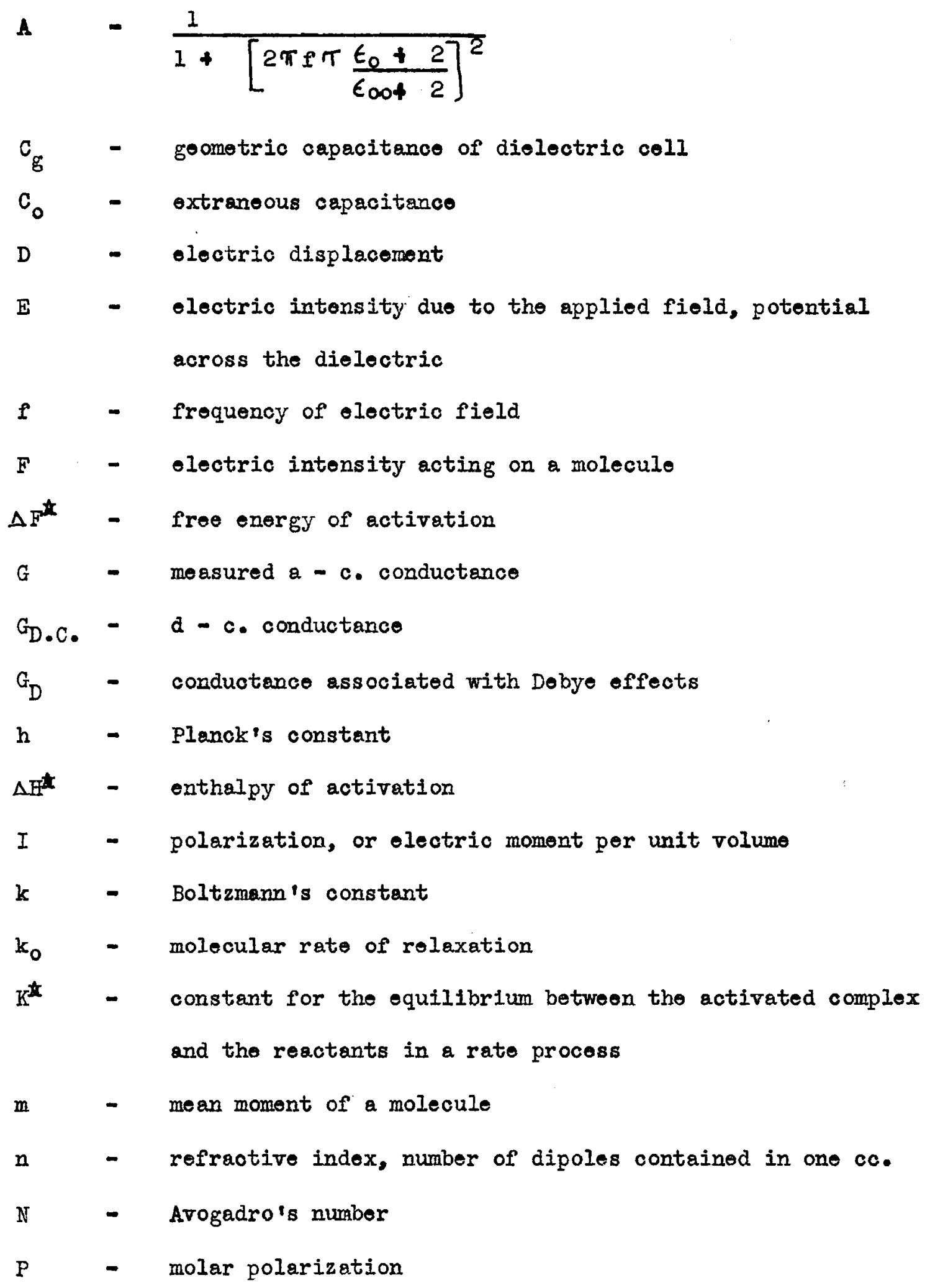




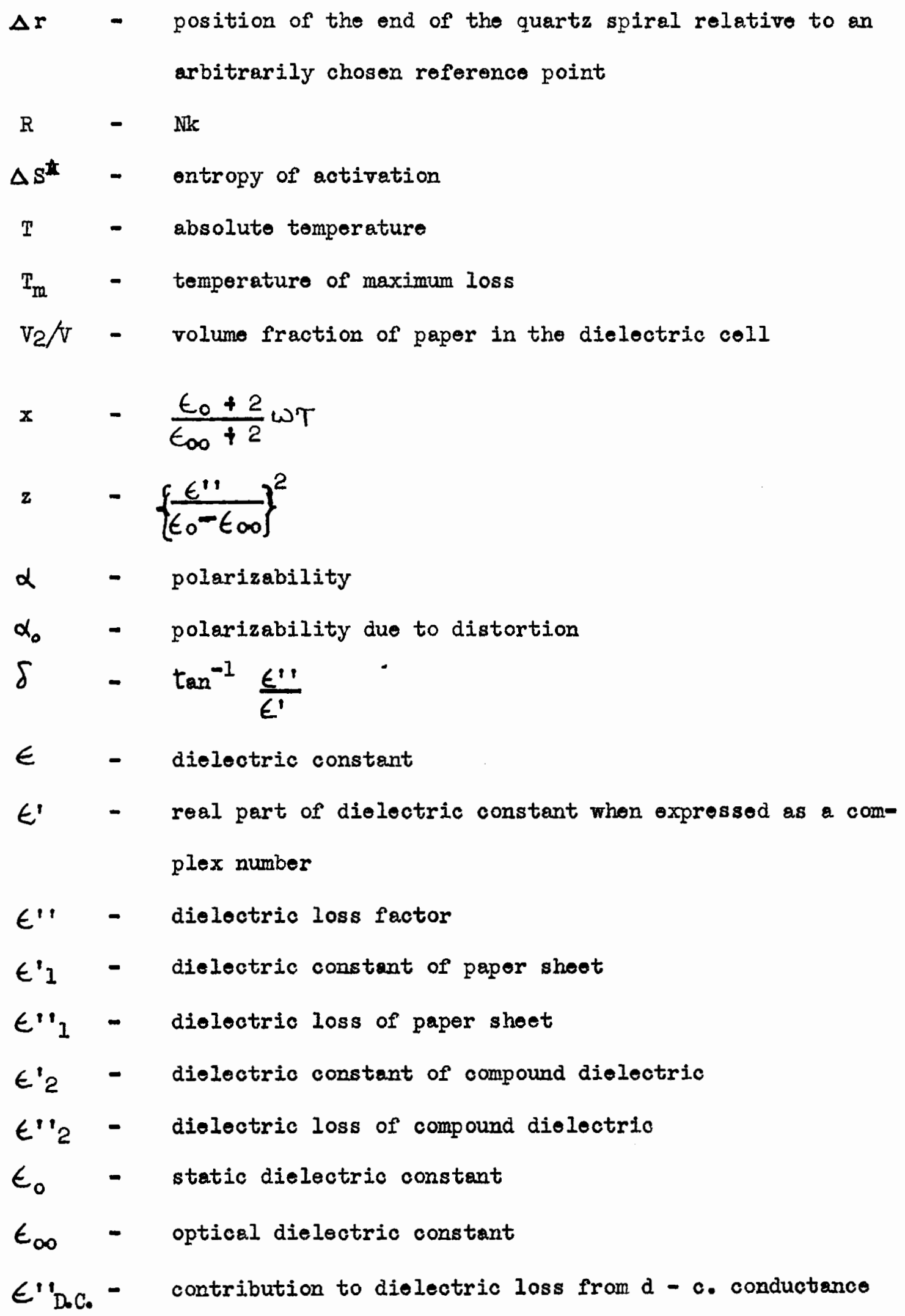




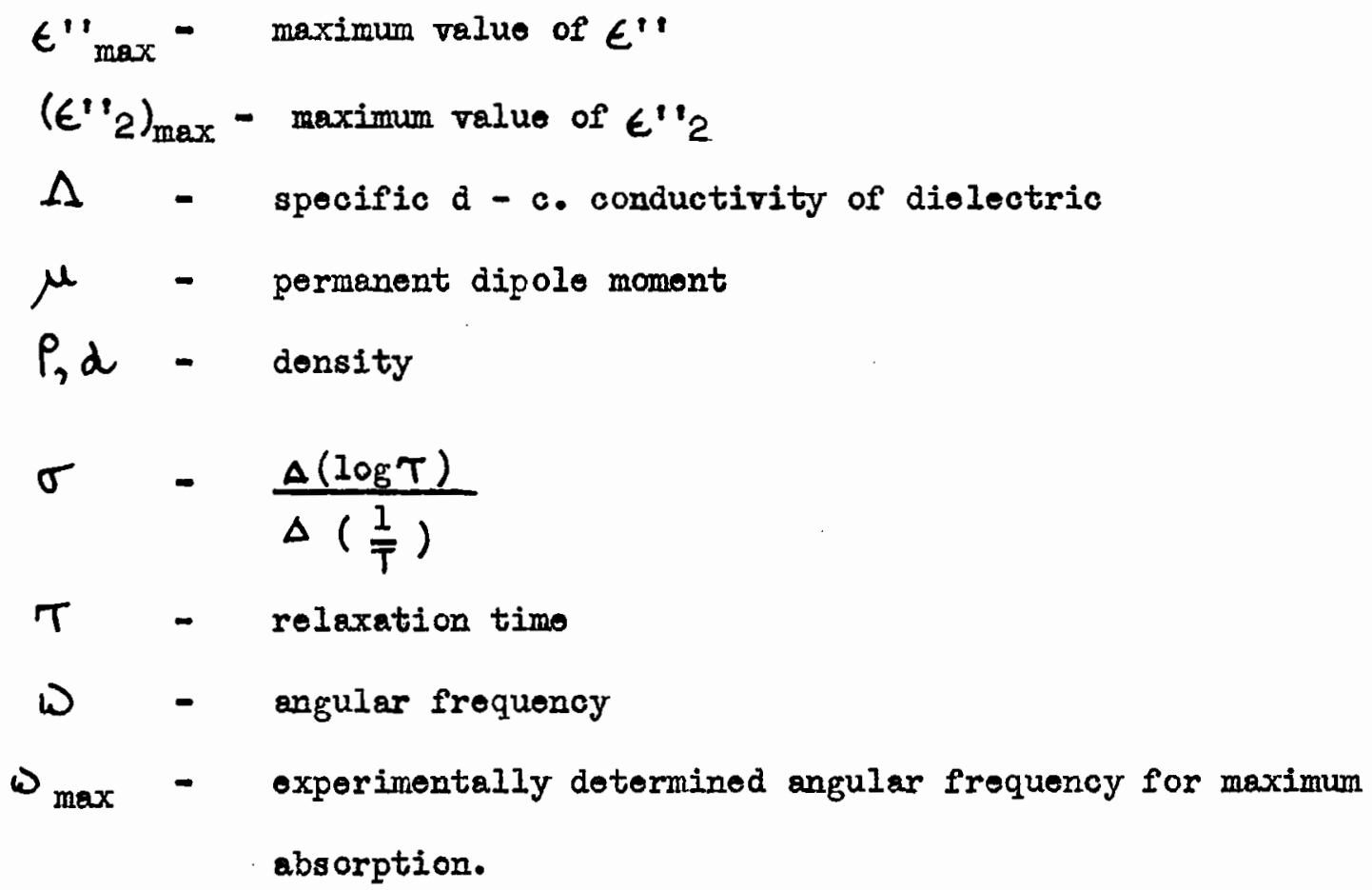


INTRODUCTION $\ldots \ldots \ldots \ldots \ldots \ldots \ldots \ldots \ldots \ldots \ldots \ldots \ldots \ldots \ldots \ldots \ldots \ldots \ldots$

EXPERIMENTAL ................................... 22

Eloctrical Apparatus $\ldots \ldots \ldots \ldots \ldots \ldots \ldots \ldots \ldots \ldots \ldots \ldots . \ldots 22$

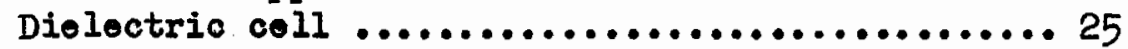

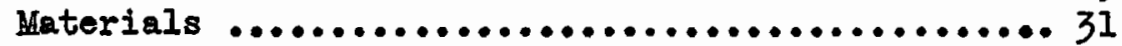

Method ................................. 32

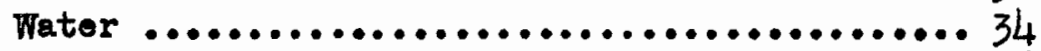

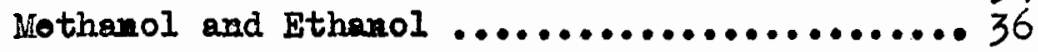

RESULTS $\ldots \ldots \ldots \ldots \ldots \ldots \ldots \ldots \ldots \ldots \ldots \ldots \ldots \ldots \ldots \ldots \ldots \ldots \ldots \ldots \ldots \ldots . \ldots \ldots \ldots$

Water .................................. 40

Preliminary $\ldots \ldots \ldots \ldots \ldots \ldots \ldots \ldots \ldots \ldots \ldots \ldots \ldots . \ldots \ldots$

Results ............................. 44

Methanol and Ethanol ..................... 56

DISCUSSION OF RESULTS $\ldots \ldots \ldots \ldots \ldots \ldots \ldots \ldots \ldots \ldots \ldots \ldots \ldots \ldots \ldots \ldots . \ldots$

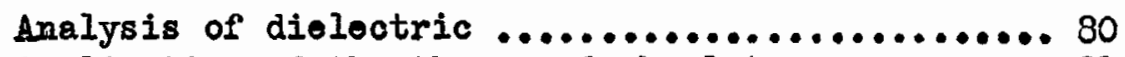
Application of the theory of absolute ........... 91 reaction ratos

Effect of rapor content on increase in .......... 98 loss maximum

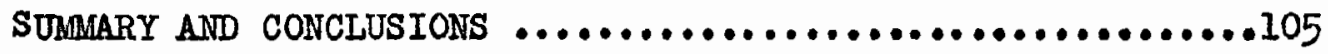

CLATMS OF ORIGINAL WORK AND CONTRIBUTIONS TO KNOWLEDGE .....107

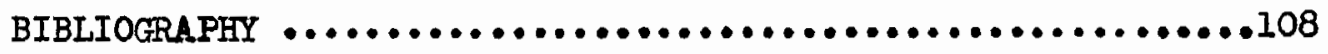




\section{INTRODUCTION}

This work is based upon a group of experiments planned to reveal certain effects of water and other hydroxyl-containing substances on dielectric relaxation in cellulose. It is, therefore, appropriate to begin with an exposition of the theoretical considerations underlying the fundamental Debye equations for the dielectric constant and loss as well as the relexation time of a dielectric (13). It is relevant as well to consider Eyring's pieture of dielectric relaxation as an activated rate process. Following this, pertinent aspects of the structure and general properties of cellulose will be traced (33). Finally, work done on the dielectric properties of this system will be reviewed.

Assuming the existence of a dielectric constant and confining attention to isotropic substances, the mean moment of a molecule, $m$, acted upon by a steady electric intensity $F$ can be written:

$$
\mathbf{m}=\propto F
$$

$\alpha$ is the molecular constant "polarizability". In determining $F$, in addition to considering the electrio intensity arising from the applied field, one must take due account of the reacting field as well as other related factors. The oldest problem, concerned with modia composed of non-polar molecules, can now be regarded as settled; we still awatt a completely satisfactory treatment of the case where the molecules possess permanent dipoles (18). If one assumes that the molecules are moving totally independently of each other, one obtains the relation (13):

$$
F=E+\frac{4 \pi}{3} I
$$

where $E$ is the electric intensity due to the applied field, and $I$ is the polarization, or eloctric moment per unit volume. By definition, 


$$
\begin{aligned}
I & =m \\
& =n \alpha\left(E+\frac{4 \pi}{3} I\right)
\end{aligned}
$$

where $\mathrm{n}$ is the number of dipoles contained in one co. Also by definition,

$$
\begin{aligned}
D & =E+4 \pi I \\
& =\epsilon E
\end{aligned}
$$

where $\epsilon$ is the dielectric constant of the substance. From (3), (4), and (5), one obtains:

$$
\frac{\epsilon-1}{\epsilon+2}=\frac{4 \pi}{3} n \alpha
$$

The Molar Polarization $P$ is defined:

$$
P=\frac{4 \pi}{3} N \alpha=\frac{\epsilon-1}{\epsilon+2} \frac{M}{P}
$$

where $P$ is the density and $M$ the molecular weight of the substance, and N is Arogadro's number. For polar substances whose molecules have a permanent dipole moment $\mu$, the mean electric moment is expressed by:

$$
m=\left(\alpha_{0}+\frac{\mu^{2}}{3 k T}\right) F
$$

T being the absolute temperature. The factor $\alpha_{0}$ takes care of the distortion effect, the factor $\mu^{2} / 3 \mathrm{kT}$ of the orientation effect. This contribution from orientation has been derived by the classical method eraployed by Debye (13), and, in addition, by the methods of wave mechanics (13), quantum mechanics (60), and the Born-Eeisenberg mechanics (40, 45). Thus, suming over a discrete number of states in the newer methods has given the same average moment as averaging over a continuous distribution in the classical derivation.

For a periodic field of anguler frequency w the mean moment becomes complex and is given by: 


$$
m=\left\{\frac{\mu^{2}}{3 K T} \frac{1}{1+i D T}+\alpha_{0}\right\} F
$$

and the molar polarization $P$ is expressed by:

$$
\frac{\epsilon-1}{\epsilon+2} \frac{M}{p}=P(\omega)=\frac{4 \pi N}{3}\left\{\alpha_{0}+\frac{\mu^{2}}{3 K T} \frac{1}{I+i \omega T}\right\}
$$

The relaxation time $T$ is defined as the time in seconds for the variable part of the moment distribution function to be reduced to $1 / 0$ of its initial value after instantaneous remoral of an electric field that has caused them to become oriented in a definite direction.

Two dielectric constants $\epsilon_{0}$ and $\epsilon_{\infty}$ are defined by:

$$
\begin{aligned}
& \frac{\epsilon_{\infty}-1}{\epsilon_{\infty}+2} \frac{M}{p}=\frac{4 \pi}{3} N \alpha_{0} \\
& \frac{\epsilon_{0}-1}{\epsilon_{0}+2} \frac{M}{\rho}=\frac{4 \pi}{3} N\left\{\alpha_{0}+\frac{\mu^{2}}{3 k T}\right\}
\end{aligned}
$$

According to $(10)$ the dielectric constant $\epsilon_{\infty}$ denotes the value of $\epsilon$ for high frequencies -- the optical dielectric constant -- and $t_{0}$ is the static dielectric constant, observed for $\omega=0$.

The value of $t$ as a function of frequenoy is then given by:

$$
\epsilon=\frac{\frac{\epsilon_{0}}{\epsilon_{0}+2}+i \omega T \frac{\epsilon_{00}}{\epsilon_{00}+2}}{\frac{1}{\epsilon_{0}+2}+i \omega T \frac{1}{\epsilon_{\infty}+2}}
$$


and can be writton as:

$$
\epsilon=\epsilon^{\prime}-i \epsilon^{\prime \prime}
$$

where:

$$
\left.\begin{array}{l}
\epsilon^{\prime}=\epsilon_{00}+\frac{\epsilon_{0}-t_{\infty}}{1+x^{2}} \\
\epsilon^{\prime \prime}=\frac{\epsilon_{0}-\epsilon_{00}}{1+x^{2}} x \\
x=\frac{\epsilon_{0}+2}{\epsilon_{\infty}+2} \omega T
\end{array}\right\}
$$

6' attains a maximum value when $x=1$; upon this fact rests the method generally used for the determination of $T$. In attempts to evaluate the internal field in polar liquids, Onsager and others have suggested that the factor $\epsilon_{0}+2 / \epsilon_{00}+2$ occurring in Debye's equations be replaced by unity $(2 / 4)$. In the present work the relaxation time has been evaluated as $1 / \omega_{\text {max }}$ where $\omega_{\max }$ is the experimentally determined angular frequency for meximum absorption.

Thus, when measurements are made as a function of frequency at temperature $T$ one obtains curves for $\epsilon^{\prime}$ and $\epsilon^{\prime \prime}$ as shown in Figure 1 . Over a given range of frequencies $\epsilon^{\prime}$ undergoes a rapid decrease and at the same time $C^{\prime \prime}$ goes through a maximum in the form of a symmotrical bell-shaped curve. For these phenomena a correspondence law holds stating that any effect of the frequency can likewise be obtained at constant frequency by making a corresponding change in $T$. In particular, 
$T$ is markedly dependent on the temperature as well as the viscosity $(13,30,35,41)$. consequently, it is not surprising that similar curves of $t^{\prime}$ and $t^{\prime \prime}$ are obtained when the frequency is kept constant and the temperature changed. Beoause of the greater ease of traversing a suitable temperature range then the corresponding frequency range the majority of workers in this field have chosen to change their variables in the former fashion. They have for the most part assumed that the value of the relaxation time obtained in this way from the maxima of the $\in$ ' curves was the same as that obtained at this temperature at varying frequenoy. There are those who have questioned the validity of this assumption (27, 38), but their objections do not appear to be at all sound in principle. For example two workers (27) object on the grounds that to each temperature there corresponds a characteristic dipolar structure, i.e., a different substance. If the implication is that it is the viscosity which changes, then it is this very fact which is the basis for the phenomena observed, as shown above.

On the other hand, a very simple demonstration of the equivalence of the two methods is offered as follows (29):

Lot $z=\left\{\frac{\epsilon^{\prime \prime}}{\epsilon_{0}-\epsilon_{\infty}}\right\}^{2}$

Put $\mathbf{A}=$

$$
\left.\frac{1}{1+\left[2 \pi f \tau \frac{\epsilon_{0}+2}{\epsilon_{00}+2}\right.}\right]^{2}
$$

According to Debye's theory $z=A-A^{2}$ (Equation 15). Since $\epsilon_{0}$ and $\epsilon_{\infty}$ are independent of $f$, the frequency of maximum loss $f_{m}$ is given by 
$-6-$

FIGURE 1

Variation of $\epsilon^{\prime}$ and $\epsilon^{\prime \prime}$ with $\log f$ in a dispersion region. 


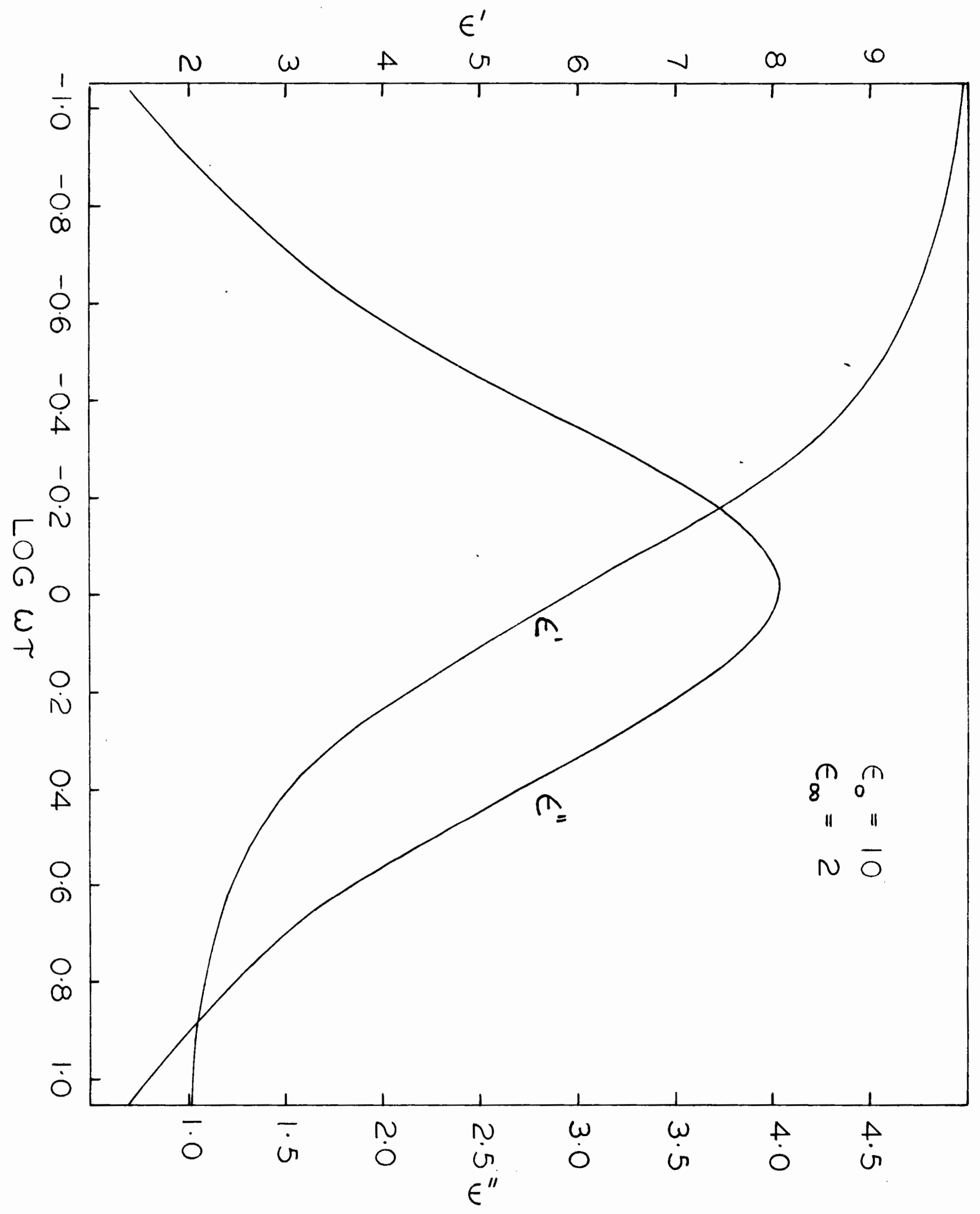




$$
\frac{d z}{d f}=0=(1-2 A) \frac{\partial A}{\partial f}
$$

The temperature $T_{m}$ whloh makes 2 a maximum is given by:

$$
\frac{d z}{d T}=0=(1-2 A) \frac{\partial A}{\partial T}
$$

In each oase the relexation time $T$ is given by the unique equation $1-2 A=0$.

The equiralence of the two methods is apparent as well in the solid model representing $\tan \delta\left(=\frac{\left.\epsilon^{\prime \prime}\right)}{\epsilon^{\prime}}\right.$ as a function of both frequency and temperature for terylene (48).

For a given field $\epsilon^{\prime \prime}$ and $D$ are related in a very simple way to the rate of loss of energy from the electric field (20). $\epsilon$ ' may then be considered as a measure of this loss.

When a dielectric is a conductor as well, there is a contribution to $\epsilon^{\prime \prime}$ which varies inversely as the frequency. Let the dielectric examined be represented by the model in Figure 2a, the phase diagram being show in Figure $2 b . C_{p}$ is the parallel capacitance, G.C. the d-c. conductence, $G_{D}$ the conductance associated with Debye effects; and $i_{1}$. $i_{2}$, and $i_{3}$ are the corresponding currents. $\phi_{\text {, and }} \phi_{2}$ are the phase angles associated with $G_{D}$ and $G_{D}+G_{D} . C_{\text {. }}$, respectively. $E$ is the potential across the dielectric. The model is then described by the following equations: 
FIGURE 2

a) Model for a conducting dipolar dielectrio.

b) Phase diagram for dielectric of Figure $2 a$. 

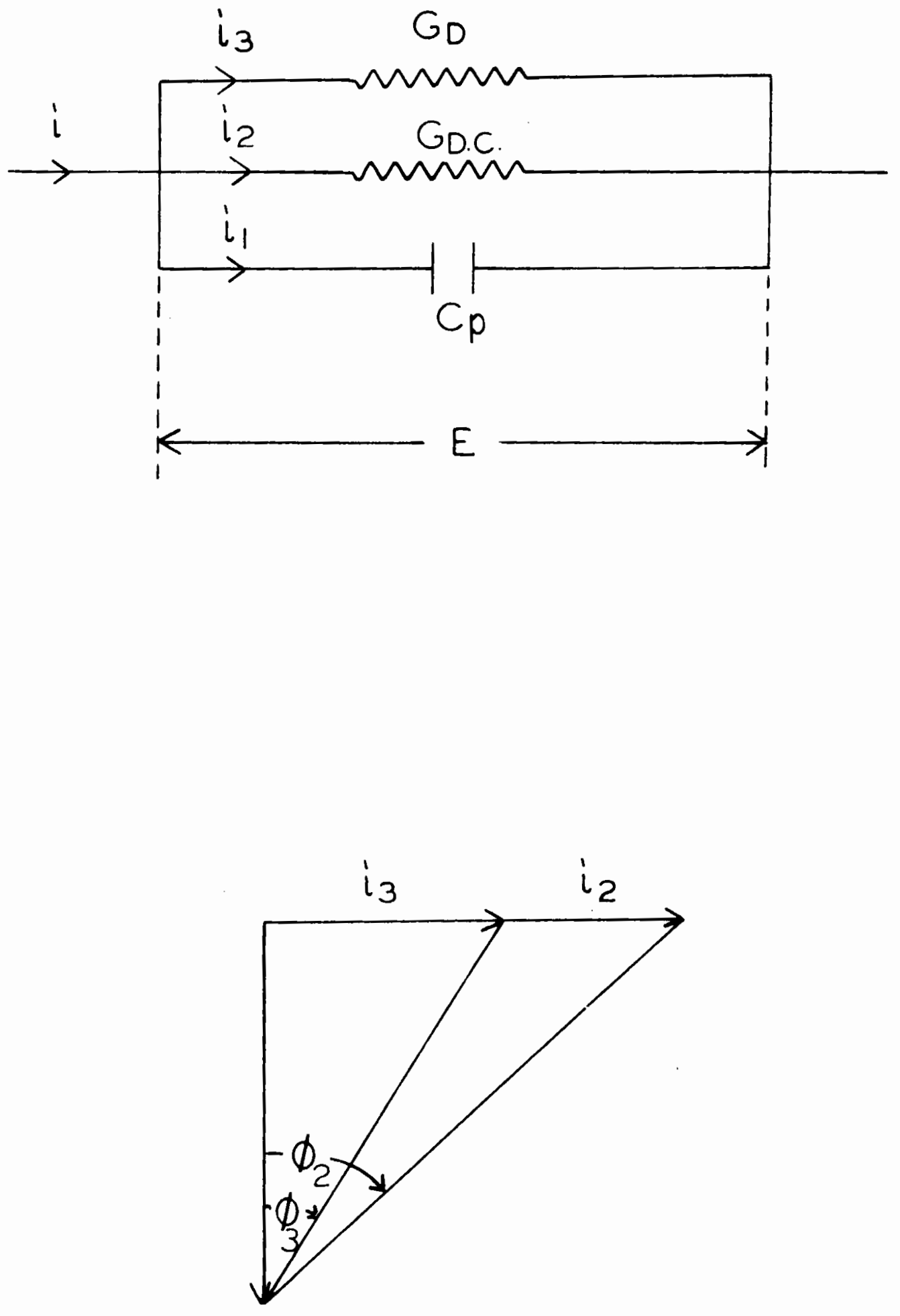


$$
\begin{aligned}
& -9- \\
& i_{1}=E_{P} ; i_{2}=E G_{D \cdot C \cdot} ; \quad i_{3}=E G_{D} \\
& \epsilon^{\prime \prime}=\epsilon^{\prime} \tan \phi_{3}=\epsilon^{\prime} \frac{i_{3}}{i_{I}}=\epsilon^{\prime} \frac{G_{D}}{\omega C_{P}}=\frac{G_{D}}{\omega C_{g}} \\
& \epsilon_{T}^{\prime \prime}=\epsilon^{\prime} \tan \phi_{2}=\epsilon^{\prime} \frac{i_{3}+i_{2}}{i_{1}}=\epsilon^{\prime} \frac{G_{D}+G_{D . C .}}{\omega C_{P}}=\frac{G_{D} \frac{i}{G_{D} C_{.}}}{\omega C_{g}} \\
& \therefore \epsilon^{\prime \prime} \text { D.C. }=\frac{G_{D \cdot C .}}{\omega C_{g}}
\end{aligned}
$$

For a parallel plate condenser

$$
\begin{aligned}
& G_{D . C .}=\Lambda \frac{a}{1} \\
& c_{g}=\epsilon_{0} \frac{a}{1}
\end{aligned}
$$

where $\Lambda$ is the specific d.c. conductivity of the dielectric and a is the cross-sectional area and 1 the length of the condenser. Therefore

$$
\begin{aligned}
\epsilon^{\prime D . C .} & =\frac{\Lambda \frac{a}{1}}{\omega \frac{\epsilon_{0}}{100} \frac{a}{1}}=\frac{1000 \times 10 \cdots}{8.85 \times 4 \pi} \times \frac{4 \pi \Lambda}{\omega} \\
& =9 \times 10 \cdots \times \frac{4 \pi \Lambda}{\omega}
\end{aligned}
$$

This is the familiar expression (9) which is quite general for condensers of all shapes.

In the treatment leading to Equations 15, it was as sumed that upon removal of an electrical field the molecule loses the impressed 
orientation by a succession of random movements, the trace of its original position becoming gradually less after each such movement. In the consideration of the process as a unimolecular reaction it was found more reasonable to assume that the dipoles change their orientation, not gradually, but in a series of sudden jumps. It was further assumed that the rate of jumping was equal to the molecular rate of relaxation $k_{0}$, where

$$
\mathbf{x}_{0}=\frac{1}{T}
$$

$k_{0}$ being analogous to the specific rate constant of chemical reactions. In the theory of absolute reaction rates (28) it is assumed that, in any atomic or molecular process whose rate is temperature dependent, the atoms or molecules involved must first come together to form what is called an activated complex. This is regarded as being situated at the top of an energy barrier lying botween the initial and final states. It is supposed that the initial reactants are always in equilibrium with the actirated complexes.

The simple expression for the rate constant of a temperature dependent process is derived to be:

$$
k_{0}=\frac{k T}{h} K
$$

where $\mathrm{K}^{\mathrm{t}}$ is the constant for the equilibrium between the activated complex and the reactants, $k$ is Boltzmann's constant, and $h$ is Plenck's constant. Writing $K^{t}$ in terms of the standard free energy of the process, $\Delta \mathrm{F}^{\mathrm{t}}$ 
$-\Delta F^{*}=\operatorname{RT} \ln K^{*}$

or $\quad \mathrm{K}^{\boldsymbol{t}}=e^{-\Delta \mathrm{F}^{\mathrm{t}} / \mathrm{RT}}$

Whence (17) becomes

$$
k_{0}=\frac{k T}{h} e^{-\frac{\Delta F^{t}}{R T}}=\frac{k T}{h} e^{-\frac{\Delta H^{t}}{R I}} e^{\frac{\Delta S^{t}}{K}}
$$

$\Delta H^{t}$ and $\Delta S^{t}$ are the standard enthalpy and entropy changes, respectively, which accompany the actiration process. Equations (16) and (18) are combined to give

$$
\frac{1}{T}=\frac{k T}{h} e^{-\frac{\Delta F t}{K I}}
$$

From Equation (19) it is seen that the rate of the process is determined, not by the heat of activation $\Delta{ }^{*}$, but by the free energy of activation $\Delta F^{t}$. Hence, if a process is characterized by a large $\Delta H^{t}$, it can still take place with rapidity if accompanied by a correspondingly large increase in entropy. On the other hand a small $\Delta H^{t}$ value does not imply a high rate if a small entropy term is involved.

It is of great interest to consider the implications of the velues that can be assumed by $\Delta S^{*}$. Many relaxation processes are characterized by large positive values of the entropy of activation, often higher than 100 o.u. For substances exhibiting such behaviour it is impossible not to conclude that more than one molecule is involred in the activation. This situation can be visualized as follows (38): 
According to the current ideas on liquid structure the state of affairs in the imnediate neighbourhood of a molecule approximates that in a crystal. Thus, in order to satisfy the requirements for stability in a normal state (where "normal" refers to a state represented by a local minimum on the potential energy surface for the system) the region in the neighbourhood of the molecule must be characterized by optimum packing, dipole orientation, hydrogen bonding (if such bonds are possible), etc. If a change is to occur in the orientation of the molecule so that its state will then be represented by a second minimum on the potential energy surface, the neighbouring molecules in the "crystal" must also undergo some change in order that the resulting configuration may again be stable. The process of activation can be easily visualized as involving a loosening of whatever bonds are holding the molecules together, so that the activated state approximates to that of a gas as far as intermolecular forces are concerned. This requires a large entropy increase comprised of the contributions of the members of the "crystal". From this actirated state the molecules can go back to their original configuration or proceed to another stable one.

Thus, if the prooess of activation is regarded as essentially a raporization, it is possible to calculate the number of molecules in the "crystal" defined above from the magnitude of $\Delta S^{*}$ and the entropy of raporization of a single molecule as calculated from Trouton's rule. At about room temperature for a substance with a molecular weight of 100, each molecule undergoes a net entropy change of 10 to 15 e.u. during the "vaporization". Consequently it can be concluded that anywhere 
up to 10 or more molecules oen be raporized in each activation process. Thus, the magnitude of $\Delta S^{t}$ in Eyring's equation gives rise to the conclusion that, in general, more than one molecule is involved in the activation process of dieloctric rolaxation. The same conclusion may bo drawn from the value of $f$ obtained from the modified Arrhonius exprossion for the rate oonstant of a procoss:

$$
k_{0}=c_{1} \frac{e^{-(A / R T+f)}\left[\frac{A}{K T}+f\right]^{f}}{f !}
$$

$f$ has been written for Hinsholwood's $(n / 2-1)$, where $n$ is the number of quadratic torms in which activation onergy is shared. $n$ is givon by $\mathbf{n}=3 a-6, n_{a}$ " boing the number of atoms in tho molecule, so that $f$ is limited by the value of a. Frank calculated the value of $f=140$ for the dioloctric rolaxation of cotyl palmitato dissolved in parafin wax. From this high value, one cannot help but conclude as before that the relaxation procoss tnvolvos several noighbouring molecules as well as the oontral one under consideration (17). Other ovidence supporting this view is presented es follows. In a binary system of two polar substances one would expect anomalous disperaion to occur over two frequency ranges corresponding to two relaxation rates. Such on effect has actually boen observed for cortain systems, but its appearance depends upon concentration as well as other factors (51). In other systems, e.g. polyvinyl chloride plasticized with varying amounts of tricresyl phosphate, a single dielectric loss maximum is observed. 
In agreement with the viows of Schallamach this suggests that it is no longor correct to speak of the relexation of single dipoles, but that larger regions must bo oonsidered (38).

Values of $\Delta s^{t}$ not far removed from zero $\left(+.79\right.$ e.u. $>\Delta s^{t}$ $X-2$ e.u.) have been interpreted es indicating that the molecules of the substance concorned are free to rotate without involving breaking of bonds to neighbours. Such behaviour is shown by the hexasubstituted benzenes (66). On the other hand, negative values of $\Delta s^{\text {t }}$ varying from - 3 to - 5 e.u. were found for several substances (65); it was thought unlikely that these negative values arose from experimental errors. In other words, the authors felt that these ralues were significant, but at the time made no statement concerning their physical import. However, others $(26,47)$ are of the opinion that the absolute rate equation is not sufficiently accurate for an absolute significance to bo placed upon the negativity of such small values. That is, the liquids involved are to be considered as merely more mobile than substances characterized by more positlve values of $\Delta S^{\star}$. This view is probably a very wise one, for it must be borne in mind that the liquids involved (toluene, o-xylene, p-cymene, etc.) were especially chosen for their very small dipole moment in order that they might be regarded as dilute solutions of dipoles in a nonpolar medium. Thus, the activation process would involve much less bondbreaking in these cases then for the associated liquids usually investigated. Fence it is not surprising that their values for $\Delta S^{\star}$ extend into negativity, especially if no absolute significance is to be placed upon them. 
It is of interest to introduce the results obtained with the seme substance dissolved in solvents of different degrees of structural order. Entropies of activation were calculated for solutions of dioctyl phthalate in both polystyrene and polythene. It is well known that, as compared to polystyrene, polythene is much mor closely packed in structure, largely owing to its crystallinity. One would consequently oxpect the nocessity for a greater disorganization, honce a greater increase in entropy, for activation in polythene. The results obtained are recorded below; they are in agreement with expectation (42).

$$
\begin{array}{lll}
\text { dioctyl phthalate in polythene } & 33 & \text { e.u. } \\
\text { dioctyl phthalate in polystyrene }-2 & -2 . u .
\end{array}
$$

Work on multicomponent dielectrics has proceded in two general directions. There are those who have with more or less success attempted to assign values of dielectric constant and loss to a particular component $(3,36,37,39,44,49)$. Then there are the others, including the present author, who, while making measurements as a function of composition, have nevertheless persisted in considering the system as a whole in this respect.

Investigations have been made on rubber swollen in turn in various polar and non-poler solvents (52). From measurements at a constant frequency it was found that in all cases the temperature of maximun loss due to rubber was shifted in varying degree to lower temperatures by an increase in concentration of swelling agent. On the other hand the loss maxima of the solvents were brought by the rubber to much higher temperatures than those of the pure liquids. In all cases the enthalpy 
of activation for rubber reloxation decreased with increasing conoentration of swelling agent, which may, therefore, be considered as having a plesticizing action on the rubber. A similar effect was produced as woll in polyvingl chloride by totralin (23), diphenyl (22), and trieresyl phosphate (11), and in polyceproemide by adsorbed water and mothanol (21). On the other hend the rulcanization of rubber with increasing amounts of sulphur $(38,53)$ is reflected in regularly increasing enthalpies and entropies of activation for relaxation. This is in agreoment with the view that the sulphur introduces added rigidity by formation of bridges botwoen chains.

Native cellulose consists of molecules having a degree of polymerization of at loast 3000 (33). What may today be regarded as the established constitution of a single molooule is represented in the follow ing formula:

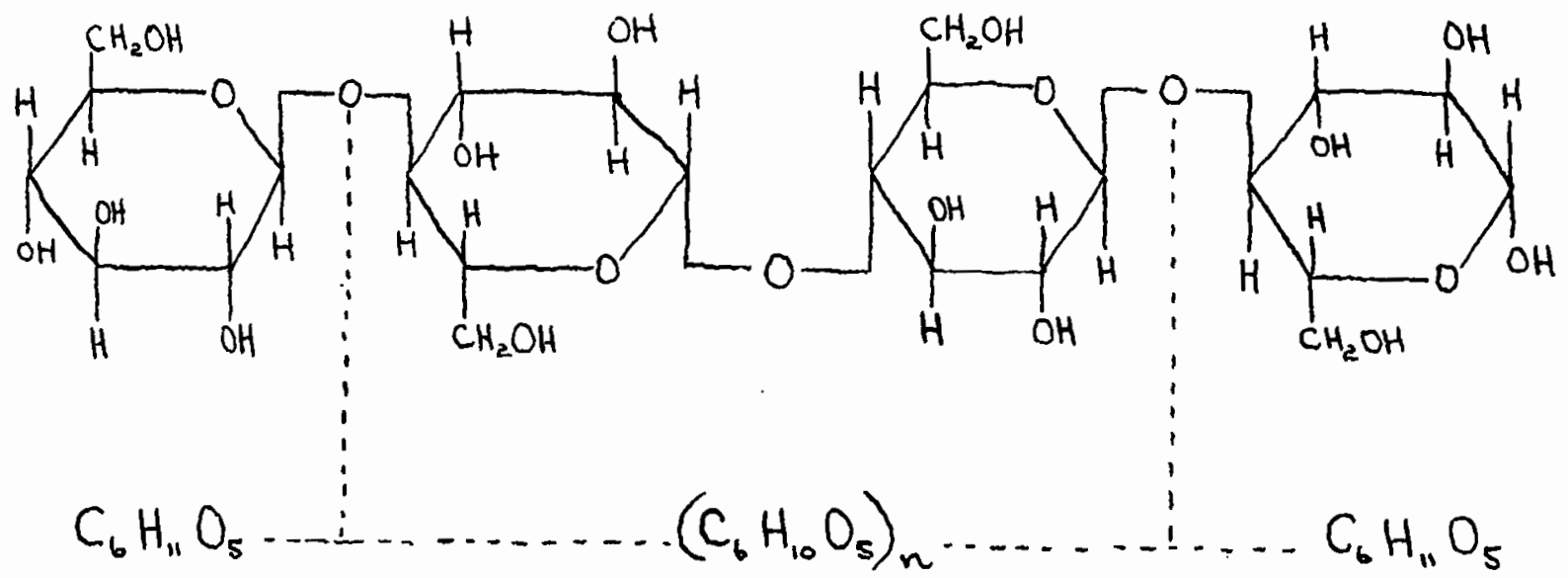

The two terminal members of a chain are differentiated from all others by the possession of four instead of three hydroxyl groups; one of these 
groups to the extreme right of the figure is distinguished by its aldehydic character. Each chain member possesses one primary group. A consideration of spatial conditions makes it plain that chains oxtending in ono direction (such as must largely constitute fibre) can only be built up by continuous $1-4$ glucosidio linkages from the frame of $\beta$ glucose in the armchair form, shown below.

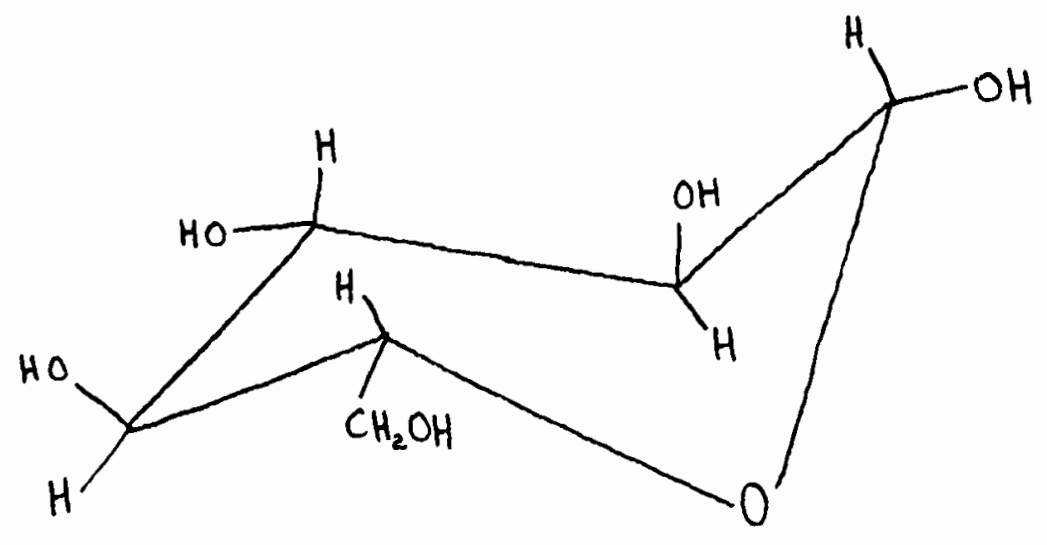

In a straight portion of the chain, the centres of gravity of the atoms of the ring are distributed over two parallel planes. The hydrophobic $\mathrm{H}$ atoms are above and below these plenes and laterally there are the hydrophilic OH groups. An arrangement of such chains in a crystal is thus easily visuelized, the "seoondary valences" of the hydroxyl groups boing taken up in the fairly powerful hydrogen bonds. The picture of cellulose fibre structure contres around the concopt of micellae, the meaning of which has undergone subtle change from the time, 70 odd years ago, when C.v. Nageli coined the term (33). They are now considered as statistically distributed regions of a latticed order in a mass of substance consisting of approximately parallel chain molocules. 
The "crystalline" regions alternate with less well-ordered "amorphous" regions, somewhat as shown below, there being no connection between the linear extonsion of the micellae and the length of the chains.

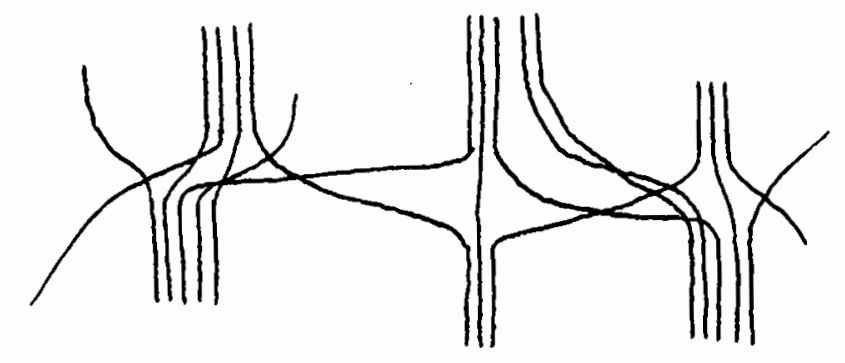

In the process of water sorption the water penetrates between the molocular chains into the fine, and even finest amorphous regions, but does not reach the core of the erystalline regions. Now if the moleculer chains are aligned in the direction of the fibre, the fibro will swell transversely only, but not longitudinally, in accordanoe with the obserred behaviour of well-oriented cellulose fibres. The sorption process is now regarded as one of solution, so that a cellulose fibre containing sorbed water may be considered as an arrangement of more or loss regularly alternating regions of crystalline mycellae and of amorphous material in solution in water.

The phenomonon of hysteresis may, after Urquhart (46), be considered as a consequence of this random arrangement of mycellae: After drying, the cellulose molecules try to attain positions such that there if the greatest posstble mutual satisfartion of secondary valences. Because of the relative immobility of the long molecules, it is not possible for them to reach the arrangemont of true minimum potential onergy. 
If the fibre is again brought into contact with water vapor, the fibre moleoules try to come into as complete a contact as possible with the water molecules; that is, they tond to become independent of each other. Howerer, in consequence of the inertia-like effoct just mentioned, the positions of the cellulose molecules at the same relativo humidity are, after drying, loss favorable to taking up water than before. In other words, the fibre behaves on desorption like a material with a higher amount of amorphous region. The fraction of amorphous rogion in native fibres has boen dotermined as 0.30 by $X-r a y$ methods, this being in good agreemont with values derived from sorption and density data $(32,34)$. Throughout this work the term "adsorbed vapor" is used to distinguish the rapor uptake on the adsorption side of the sorption isotherm from that on the desorption side.

A fundemental problem arises whonover an absolute moasuroment of the dieloctric constant of cellulose is desired. This is inhorent in the fibrous structure of the material, the porous nature of which must be circumvented in some manner if one wishes to avoid the nocessity of taking into account anomalous surface effects. Two mothods, quito simplo in principle, have been developed to this ond -- the technique of Iiquid mixtures and the pressure method.

The technique of liquid mixtures was first used by starke (55) and independently by De Luca, Campbell, and Maass (15). These authors showed that the problem of the porous spaces in cellulose could be solved by filling them with a liquid having the same dielectric constant as the cellulose itsolf. Tho mothod involves finding a liquid mixture which is 
isodieleotric with the collulose. The composition of this liquid mixture was the point of intersection of two liquid-composition versus dielectric constant curves, one with and one without the cellulose samplo in place in the condenser. The dieleotric constant of a liquid of this composition was then determined directly, or from curve showing the relation betwo on percontage composition and dielectric constant. The major uncortainty in this mothod, arising from tho small anglo at which the curros crossed, was neatly resolved by Brown (7) by simply plotting differences in dielectric constant due to cellulose rather than the composite values. An entirely different approach was employed by Delevanti and Hansen (16) and later by Calkins (8). They constructed the electrodes of their condenser in such a way that pressure could be applied to the cellulose sample up to point where it no longer had any effect on the measurements. At this point it was assumed that the pores in the sample had boen effectively eliminated.

Data obteinod by these workers will be reviewed in the discussion. Dielectrio dispersion in dry cellophone was discovered by Stoops in 1934 (57); this was attributed to typical dipolo oriontation. Analysis of his data shows no significant difforence in the values of the relaxation time $T$ whether calculated from data obtained at constant temperature, or, on the other hand, at constant frequency. There is no reason why this should not also be the case for other forms of cellulose. Because of the softening action of water on cellulose it was reasonable to assume that sorbed moisture facilitates dipolo rotation and thus appropriately shifts the position of maximum absorption. Somo 
data was arailable on this subject but the results apposred contradietory. Dakin and Auxier (10) mossured tho diolectric constant and dissipation factor of commercial papers as a function of frequency at $28^{\circ} \mathrm{c}$. When observablo, the frequency of maximm absorption was unaffected by the moisture content. Similar mossurements by Henniger (31) at $-5^{\circ} \mathrm{C}$. for paper with molsture contents of 0 and $5.6 \%$ gave the same general results. On the other hand Veith moasured the dissipation factor of paper at different moisture contents as a function of temperature over the range -40 to $40^{\circ} \mathrm{C}$. at fixed frequencies (61). The temperature of maximum loss, observed only at the highest experimental frequency, 100 Kc., appeared to decrease with increasing moisture content. In view of this conflicting evidence further investigation appeared desirable. It was docided to work with a purified form of cellulose in order to oliminate effects due to high loss impurities. The working frequencies chosen were such that abserption regions appeared in the temperature range -60 to $45^{\circ} \mathrm{C}$. 
EXPERIMENTAI

Eloctríoal Apparatus

For the frequency range of $10 \mathrm{Kc}$. to $1 \mathrm{Mc}$. covered in this work, two moasuring oircuits used proviously in this laboratory (24, 25) were employod. These were the General Radio Company's Typo 821-A Twin-T Impedanco measuring circutt and the Type 716-C Schering bridge. Tho Twin-T eireuit togothor with auxiliary oquipmont was omployod at 1 and $.55 \mathrm{Mc}$. The arrangement and mothod of operation wer. essentially the same as that used previously, the circuit being shown in Figure 3. The appropriate high-froquency signal gonerated by the oscillator was amplified and then fed into tho Trin-T circuit. In tho absence of balance conditions in this circuit part of the carrier signal ontered the radio receiver. An internal beat oscillator in the receiver was omployed to produce beats with the carrier signal. This hoterodyne signal was amplified and could be hoard through earphones plugged into jacks in the recoiver. On boloncing the Twin-T cirouit, the signal no longer entered the detector and no sound could be hoard. At 200 and $100 \mathrm{Kc}$. the Schering bridge was employed. The appropriate signal was fod into the bridge from the amo oscillatoramplifier arrangement used with the Twin-T circuit; the mothod of null detection was likewise the same. In this case the null detector was the RCA Victor Typ T.E.-236-B Radio Recoiving Equipmont consisting of a Power Unit, MI-22102, and a Receiver Unit, MI-22112. 
$-23-$

FIGURE 3

Twin-T circuit and auxillary apparatus. 


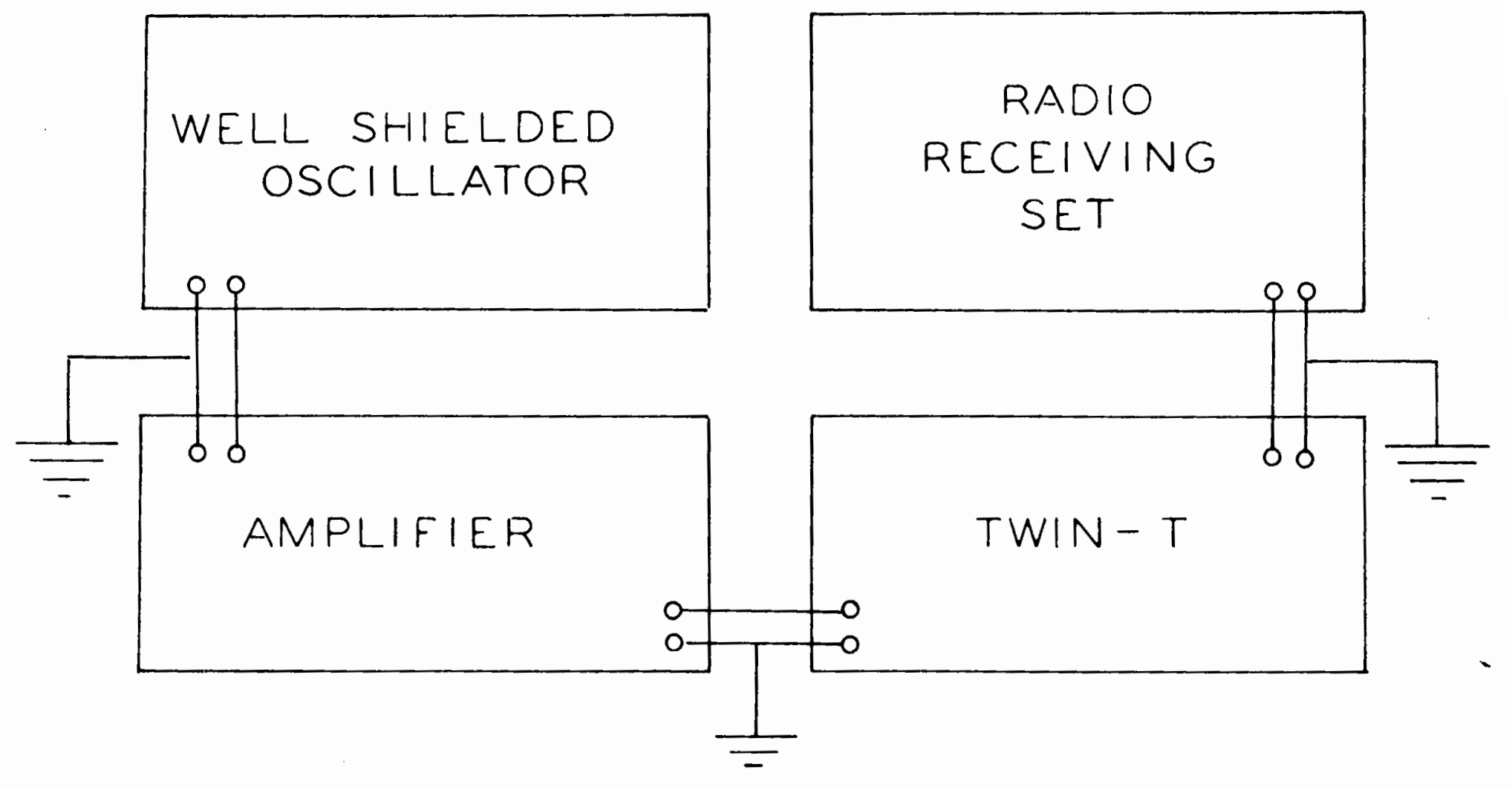


This equipment could detect signals in the range 15-600 Kc. The Power Unit was carefully designed in order to maintain an accurate calibration of the recoiver and high degree of frequency stability. The Recoiver Unit was complotely shielded both internally and oxternally to minimize cross-talk betweon receivers. Filters were provided which increased the effective CW selectivity and improved the signal-to-noise ratio. C.W. reception and improved sensitivity and selectivity was accomplished by the use of a specially designed autodyne detector cirouit. This detootor omployed the familiar eloctron coupling with the resultant minimizing of reaction in all circuit switching in tho audio systom. A very high degree of frequency stability is inhorent in this type of oircuit which ronders it possible to obtain the desired performance characteristios of this detector without oritioal adjustment of the controls. These were sot as follows:

With the "Frequency Band" switch sot at the appropriate from quency range, the "Turing" control was adjusted until the desired signal was heard. The "Regeneration" control was set so that the detector was osoillating as evidenced by a doublo click hoard in the hoadphones when the "Osc. Test" button was pressed and released. The "Sonsitivity" control was set at 6; this gave the required sensitivity without overloading the receiver with noise. The "Antenna Trimmer" and "RF Trimmer" controls were kept in the same position for both frequenoies, while the "AVC" and "Audio Tuning Off-On" switches were at all times kept in the "Off" position. 
at 30 and $10 \mathrm{KC.}$, the auxiliary equipment and general arrangement of the circuit boing ossentially similar to that omployed previously (24). The bridge was onergized by a Hewlett-Fackard No. 200A Audio Oscillator. The oscillator signal was fed to the bridge and thonce through a HowlettPackard Model 404A vecuum tube voltmeter amplifier oircuit to 5-in. Sylrania cathode ray osoilloscope which served as null detector. The method of null deteotion was a eimplification of that employed proviously. The signal, which was applied to the "y" plates of the osoilloscope was beat against an appropriate internal oscillation applied across the " $x "$ plates. This resulted in a wave-form on the oscilloscope scroon the amplitude of which was reduced to zero upon balancing of the bridge. Thus, the principle of operation of all three arrangements is offectively the same. In each oase the reforence for measurement is the condition of zero energy transfer across the measuring circuit. In each ease the rosidual signal transforred across the unbalaneed oirout is beat against on internal oscillation in the null detector. On the one hand the resultant electrical oscillation is transformed to an audible sound wave, on the other hand it becomes visible lectron wave. D-c. resistence measurements were made with a General Radio Type 1861-A Negohmeter. With few excoption to be mentioned below, there was no approciable contribution to the measured a-0. 108808 (800 Introduction).

Diolectric cell

It was necossary to design a coll in which the vapor oontent 
$-26-$

FIGURE 4

Dieloctric coll. 


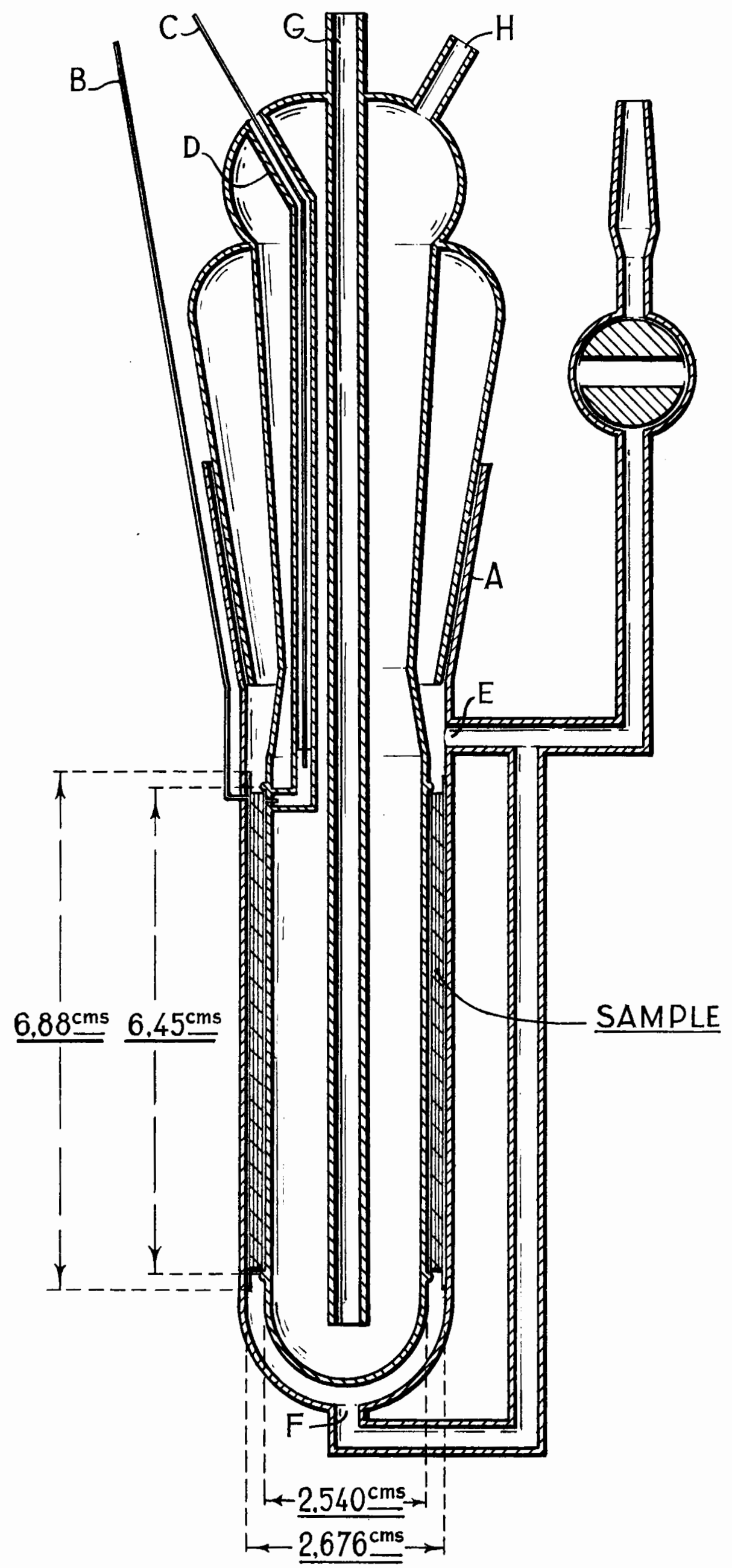


of the collulose sample could be systematically raried.

The arrangoment omployed (Figure 4) consisted of a pair of concontric Pyrox glass cylindors oonnooted at a standard-taper groundglass joint $A$. On the gless wall at oach side of the annular space three layers of platinum were doposited; these constituted the eloctrodes. Contact was made to copper wires $B$ and $C$ on the outside by thin pieces of platinum sealed in the glass. The eopper wire $C$ dipped into mercury at the bottem of the tube $D$, the moroury making contect with the platinum soled in the glass. Connection to the conditioning system was made both above and belon the eloctrode deposit at $E$ and $F$ in order to accelorate diffusion of vapor throughout the cellulose sample. Four tiny blebs of glass wore sealed both above and below the eloctrode on the inner eylinder to serve as spacers for the somple. Two trabes $G$ and $\mathrm{E}$ were to make provision for ciroulation of thermostatted liquid through the inner oylinder; no necossity was found for this application of the tubes.

Such colls, in which motal oloctrodes aro deposited on glass, wore introduced by Sayce and Briscoe in 1925, and have since boen used with success $(5,12,58)$. Because of the small coefficient of thermal expansion of glass, cells of this typo have no eppreciable tomporature coefficient of capacity. Thus, there was effectivoly no variation in capacitence of the cell over the 80-degree range covered in this work. Connection of the oell to each measuring circuit was made by immersion of the copper loads B and C (Figure 4) in mercury contained in small tubes, to the bottom of which the loads from the measuring eir 
cuit wore sealed with Glyptal coment. These loads were two copper wires, 13 in. Iong B. and S. No. 20 guage, kept about one inch apart by threo narrow pieces of lucite. The connecting mercury tubes were mounted on a masonite board which also served to support the cell.

The cell was calibrated with dry benzene at $25.0^{\circ} \mathrm{C}$. Assuming the value of 2.274 for the dielectrio constant of benzene at this temperature (6), the geometric capacitance (Cg) was found to be $68.0 \mathrm{\mu \mu f.,}$ while the extrancous capacitanco $\left(C_{0}\right)$ including loads was $9.7 \mu \mu f$. In the oase of the schering bridge the dieloctric oonstent, $\epsilon^{\prime} 2$, and dielectric loss, $\epsilon^{\prime} ' 2$, wero determined by the substitution mothod as follows:

$$
\begin{aligned}
C x & =\Delta C \\
D x & =\frac{.02 C^{\prime}}{\Delta C} \frac{f}{f_{0}} \Delta \\
\epsilon_{2}^{\prime} & =\frac{C_{x}-C_{0}}{C_{g}} \\
\epsilon^{\prime \prime} 2 & =\epsilon_{2}^{\prime} D_{x}
\end{aligned}
$$

$\Delta C$ and $\Delta D$ are the bridge readinge and $C X$ and $D X$ the actual ralues of the parallel capacitance and dissipation factor of the unknown. $C$ ' is the capacitance reading with the unionown disconnected, $f_{0}$ is the frequeney setting of the range selector switch, and $f$ the working frequeney. The simplicity of equations (1) and (2) rosults from the fact that in no case in this work was the measurod dissipation factor of the uaknown greater than 0.1 .

In the case of the Twin-T circuit it was nocessary to correot the capacitance roading $\Delta C$ for the lead inductance $L$, in ordor to obtain the true capacitance $C_{x}$, the rolation among which is expressed in: 


$$
\frac{1}{\Delta C}=\frac{1}{c_{x}}-\omega^{2} I_{1}
$$

where $\omega$ is the angular froquency of measurement. $I_{I}$ was obtained from a plot of $1 / \Delta C$ versus $w^{2}$ as $9.9 \times 10^{-7} \mathrm{~h}$. on the basis of two independent determinations for the empty cell and for the coll filled with benzene. The value of the internal load inductanco of the precision oondonser did not contribute appreciebly to $I_{1}$.

Equation (5) defines the corroction factor assooiated with $L_{1}$ as follows:

$$
\gamma=1+4)^{2} L_{1} \Delta C
$$

Velues of $\gamma$ for varying $\Delta C$ at .55 and $1 \mathrm{Mc}$, are presented in Table $I$. The unknown oapacitance was thon given by:

$$
c_{x}=\frac{\Delta c}{\gamma}
$$

the dielectric constant being obtained from Equation (3).

No other corrections of this nature were found to be necessary. The conductance $G$ was obtained by subtracting from the measured value a small mount equal to the value for the ompty cell. The dielectric loss was calculated from this as follows:

$$
\epsilon^{\prime \prime}=\frac{G\left(f / f_{0}\right)^{2}}{\uparrow c_{g}}
$$

where $f_{0}$ is the nominal switch-position frequency and $f$ the frequency of measurement. 
$-30-$

\section{TABLE I}

Correction Factor $\gamma$ for loed inductance

\begin{tabular}{|c|c|c|}
\hline \multirow{2}{*}{$\Delta c$} & \multicolumn{2}{|c|}{$\gamma$} \\
\hline & .55 Mc. & $1 \mathrm{Mo}$. \\
\hline 70 & 1.001 & 1.003 \\
\hline 80 & & \\
\hline 90 & & 1.004 \\
\hline 100 & & \\
\hline 110 & & \\
\hline 120 & & 1.005 \\
\hline 130 & 1.002 & \\
\hline 140 & & 1.006 \\
\hline 150 & & \\
\hline 160 & & \\
\hline 170 & & 1.007 \\
\hline
\end{tabular}


Materials

The cellulose investigatod was a sample from Schleicher and Schuell No. 589 Red Ribbon quantitative filter papor of an extra donse quality, with a reported ash content of $0.007 \%$. Microscopic examination of the paper indicated it to be a rag furnish oontaining $75 \%$ bast fibro and $25 \%$ cotton. Tho analysis was as follows:

$$
\begin{array}{lc}
\alpha \text {-oellulose } & 98.4 \% \\
\text { pentesan } & 1.1 \% \\
\text { cupriethylene diamine viscosity } & 15.7 \text { centipoises }
\end{array}
$$

Saturated salt solutions to be used for conditioning the paper at different water contents were propared from the following reagents:
1) Lithium chloride -- Baker's Analyzed, C.P. Grade
2) Potassium acetate - Eimer \& Amond, C.P. Grade
3) Magnesium chlerido -- Morck, Reagent Grade
4) Potassium carbonate -- Merck, Reagent Grade
5) Magnesium nitrate -- Merck, Reagent Grade
6) Ammonium sulphate -- Merck, Reagent Grade
7) Ammonium phosphate -- Morck, Reagent Grade

Absolute othanol from the Canadian Industrial Alcohol Company, Limited was dried according to the method of Lund and Bjerrum (43). The reaction mixture was used as a source of dry vapor, the density of the distillate at $25.001 .05^{\circ} \mathrm{C}$. being .7852 compared with .7850 reported by Lund and Bjorrum.

The sample of methanol used was dried in the same way as the ethanol. 
Mothod

A simple system shown in Figure 5 provided the means of equilibrating the paper in the cell at different vapor contents. The di-lectric cell was connected at A. B contained the vapor source, while the equilibrium vapor pressure was measured to $0.1 \mathrm{~mm}$. with the U-tube morcury manometer $c$. The rapor content in each oase was determined to less than 0.1 percent using a quartz spiral mounted in the sorption cell D. Both colls and the vapor tube were thermostatted at $25.00 \pm .05^{\circ} \mathrm{C}$. in the same water bath E. The buoyanoy of tho large sorption cell in the water was counteracted by mercury.

The quartz spiral, having a diameter of $5 / 8$ inch, was capable of supporting $100 \mathrm{mg}$. with a sensitivity of from $0.1 \mathrm{mg}$. to $0.01 \mathrm{mg}$. The percentage vapor content of a $103 \mathrm{mg}$. sample of paper suspended from the spiral by a small platinum hook wes determined by the corresponding percentage change in length of the spiral using a cathotometer reading to $\pm 0.03 \mathrm{~mm}$. This corresponded to an orror of less than $0.1 \mathrm{mg}$. Hooke's law was oboyod within the accuracy of measuroment over the range covered.

The reforence from which all measurements were made was the clearly defined bottom of the projection at $F$, while the extension of the spiral was determined by the position of the top of the platinur hook. These two readings were always taken for each measurement. The difference $\Delta r$ was $-17.68 \mathrm{~mm}$. for the spiral and platinum hook. With the dry paper suspended $\Delta r$ was $27.60 \mathrm{~mm}$. so that the extension of the spiral due to the dry paper was 17.68 plus 27.60 oqual to $45.28 \mathrm{~mm}$. 
$-33-$

FIGURE 5

Conditioning system. 


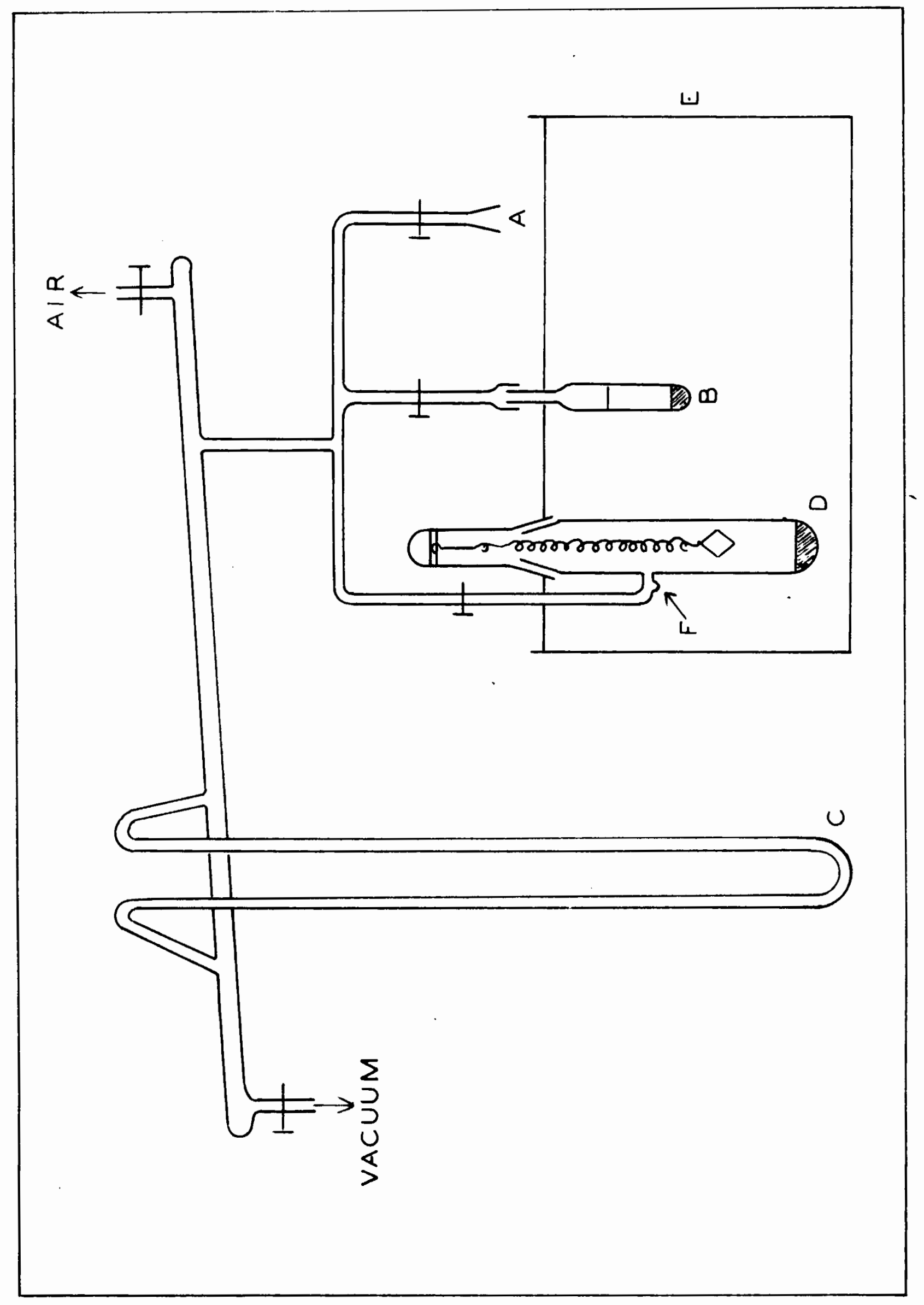


Water

A strip of paper was tightly wrapped around the inner cylinder of the dielectric cell botween the spacers and hold in place by moans of Glyptal cement. The cell with the paper fitting snugly into the annular space was assembled and connected to the conditioning system, through which it was eracuated with a Cenco Hyvac purm orer a period of 20 hours to bring the sample to drynoss. The result was dry paper as definod in this work, although there presumably remained a small residual amount of water which required more drastic mothods for removal (33).

As a matter of fact, it is possiblo to estimate this residual from date obtained by Wahba on the heat of wotting of standard cellulose (63, 64). During the courso of experiments plenned to determine optimum conditions for drying, it was found that the heat of wetting for standard cellulose driod in vacuo for 15 hours at $25^{\circ} \mathrm{C}$. is 9.7 cals. $/ \mathrm{gm}$. dry material. This corresponded to a moisture content of $0.4 \%$, which is probably the value of the residual in the dry sample of this work.

A series of dielectric measurements (described below) was then carriod out.

The coll was then reconnocted to the conditioning systom and filled with vapor from the potassium acetate solution, forty-oight hours boing allowod for oquilibrium to be established. At this point tho coll was disconnocted and dielectric moasuroments carried out as before. This procedure was then repoated for each of the other salt solutions. The criterion for moisture equilibrium of the paper was the constancy of the equilibrium vapor prossure as well as of the extension of the quartz 
spiral, the paper on which was subjected to the samo experimental conditions of temperature and rolative humidity as the papor in the dielectric coll.

Aftor oquilibration at each moisture content a series of di-loctric runs was carried out at oach of soveral different frequencies over a temperature range of $-58^{\circ} \mathrm{C}$. to $26^{\circ} \mathrm{C}$. The dieleotric cell was imorsod in a dewar flask filled with toluone. Using a small Variaccontrolled heater, the temperature was raised to $26^{\circ} \mathrm{C}$. at the rate of one degreo per minuto. Aftor the cell was allowed to como to thormal equilibrium, appropriate readings of capacitance and dielectric loss wore takon. The bath was thon cooled with dry ice and readings wore taken at rogular intervals at successively lowor temperatures down to $-58^{\circ} \mathrm{C}$. For each reading a cooling period of from six to eight minutes was provided, and an additional ten minutes was allowed for the cell to reach thermal equilibrium. Tho temperaturos were read on a toluene thermometer, the ice point of which was found to be correct within experimental error. After reaching the lowest temporature the frequency was changed and similar moasuroments woro made at increasing temperaturos.

Thus, some of the runs were performod by going up the tomperature scale, other by going down. By determining a complete cycle at a single frequency, it was shown that thore was no temperature hysteresis, i.o., the direction of temperature change had no effect on the readings taken. The run performed at the first froquency was always repoated at the ond of the series for a particular vapor content, and in all cases was found to be reproducible. Somo slight exception to this generali- 
zation was found in the work with mothanol and othanol, and will bo described in the next section.

With dry paper a marked temperature hysteresis was observed. This resulted from the low thermal conductivity in the evacuated coll. Whon dry nitrogon was admittod this offoct disappoared without changing the moasured capacitance at roon tomperature. The nitrogen (and in othor instances the water rapor) thus sorved as tho necessary heat conductor. Moasuromonts with the coll, omptiod of paper, and filled with water vapor at the highest prossure omployed in the work on dielectric relaxation showed that the variation of electrical proportios was negligible with respect to tomporature and to water vapor pressure. Before equilibrating the paper in the cells at a given vapor content, it wes nocessary to remove from tho vapor source any dissolved gases which might be adsorbed by the paper in addition to the vapor in question. This was accomplishod in some cases by simple evacuation, and in othors by a procoss of ropeated froozing, evacuation, and molting, as described by Archer (1).

Mothanol and Ethanol

In the exporimonts with methanol and othanol it was nocessary to aroid exposure of the stopcocks in the conditioning system to aloohol vapors for the weoks necessary for a complete run (50). Furthermore, since mothanol (50) and presumably othanol cannot be complotely romoved from collulose by oracuation at room temporaturo, it appeared desirablo to use as reference for the measurements not only the paper in a dry 
condition but whon containing those tightly hold portions of alcohol as woll. The following modifications of the above procedure were accordingly adoptod.

Mothanol vapor was admittod to the conditioning systom at a pressure of $60 \mathrm{~mm}$. and allowed to romain in contact with the proviously dried paper for two hours. The system was then ovacuated over a second period of two hours. This process was ropeated twice, the final oracuation boing extended over a period of twolve hours. At this point the mothanol content was $1.7 \%$. Aftor a series of dieloctric moasuromonts was performed as described above, the paper was conditioned to a mothanol content of $2.5 \%$ and a furthor series of dielectric measurements performed. The paper was then subjocted to a further process of alternate methanol conditionings and series of dieloctric moasurements up to a mothonol contont of $7.0 \%$. Before oach conditioning air was admitted to the aystem to permit rogroasing of stopcooks, after which ovacuation was carriod out over period of twelve hours, es before. With one exception, the emount of tightly bound methanol dotormined after the oracuation was always roproducible within exporimental orror.

After the exporimonts on methanol woro comploted, this residual was removed as follows. Water vapor was admitted to the system at $100 \%$ R.H. and allowed to remain in contact with the paper for soveral hours. The systom was thon oracuated over a period of 15 hours, the whole process being repeated once. In this way $85 \%$ of the residual mothanol was romored, so that there remained an amount equal to $0.2 \%$ by wight of the dry paper. 
The paper was then conditioned to an ethanol content of $8.5 \%$, after which dielectric measurements woro performed, as usual. Eracuation of the system for six hours loft $2.3 \%$ residual othanol none of which was removed after a subsequent oracuation lasting 14 hours. Dielectric moasurements were performed at this othanol content as woll as at 4.6 and $6.9 \%$ ethanol. Before each of the latter conditionings, air was admitted to the systom, this being followed by ovacuation over a poriod of twolvo hours, as in the case of mothanol. Altogether, threo samples of paper wore omployed for the diolectric moasurements in the course of this work. Sample \#l was used for the preliminary moasurements on water, \#2 for the major work on water, while \#3 was used for the work on mothanol and othanol. The relaxation data to be discussed later woro roproducible, but slight differonces wore found in the absolute values of dielectric constant and 108s. These con partly be acounted for on the basis of corrosponding differonoes in samplo size, and will in fact be discussed below in the section on the analysis of the dieloctric. The dimensions of the samples and the di-lectric coll as woll as the appropriate volume fractions are prosented in Table II. It is observed that the geomotric capacitance of the di- loctric coll calculated from the cell dimonsions is in good agroomont with the value detorminod experimontally. 
TABLE II

Sample dimensions and rolume fractions in dielectric cell

\begin{tabular}{|c|c|c|c|c|c|c|c|}
\hline Samplo & $\begin{array}{l}\text { Longth } \\
\text { (ins.) }\end{array}$ & $\begin{array}{l}\text { Width } \\
\text { (ins.) }\end{array}$ & $\begin{array}{l}\text { Thickness } \\
\text { (ins.) }\end{array}$ & $\begin{array}{l}\text { Volume } \\
\text { (cc.) }\end{array}$ & $\begin{array}{l}\text { Woight } \\
\text { (gm.) }\end{array}$ & $\begin{array}{l}\text { Density } \\
\text { (gm/cc) }\end{array}$ & $\begin{array}{l}\text { Vol. Fraction } \\
\text { in cell }\end{array}$ \\
\hline 1 & 8.85 & 2.63 & .0063 & 2.40 & 1.251 & .521 & .630 \\
\hline 2 & 8.91 & 2.59 & & 2.38 & 1.182 & .496 & .625 \\
\hline 3 & 8.88 & 2.64 & & 2.42 & 1.202 & .496 & .635 \\
\hline
\end{tabular}

$$
\begin{aligned}
& \text { Diamoter of Outer electrode }=d_{0}=1.051 \mathrm{ins.} \\
& \text { Diameter of inner eloctrode }=d_{i}=.994 \text { ins. } \\
& \text { Length of Outer electrode }=1_{0}=2.71 \text { ins. } \\
& \text { Longth of innor lectrode }=I_{i}=2.54 \text { ins. } \\
& \text { Volume of interelectrode space }=\frac{\pi l_{i}}{4}\left(d_{0}+d_{i}\right)\left(d_{0}-d_{i}\right) \\
& =3.81 \mathrm{ce} . \\
& \text { Goomotric oap. of cell (calc.) }=64.4 \mu \mu f \text {. } \\
& \text { (expt1.) = } 68.0 \mu \mu f .
\end{aligned}
$$


RESULTS

Water

\section{1) Proliminary}

Preliminary results wero obtained with dieloctrio coll used proviously in this laboratory (25) which had not been designod to be air-tight. Shifts in the position of the dispersion region for identical runs on successive days were as high as $20^{\circ} \mathrm{C}$. At the same time distortion of the shape of the loss curve was observed, the magnitude of the offeot varying from day to day. This was tracod to varying amounts of moisture condensing on the bakelite insulation botwoon the condenser plates during a rua. This in turn was caused by corresponding changes in the relative humidity of the air on successive days, the best curves being obtained at lower relative humiditios. Experimonts performod on the empty coll showed that the maximum variation in loss could approach values observed for the coll filled with paper. The spurious rosults obtainod were at once oxplained by the change in electrical properties with moisture content of the bakelite insulation as well as of the paper itself.

This early work suggested the foasibility of seoking a corrolation between the shift in position of the dispersion region in paper and the amount of sorbed water it contained. The air-tight design of the dielectric cell of Figure 4 made it suitable for this purpose. Moreover, there was no danger of spurious results due to hygrosoopic insulation, as the condenser platos woro positioned solely by the ground-glass joint 
aituated woll above the upper boundary of the plates.

Data was obtainod at $1000 \mathrm{Kc}$. for paper containing water adsorbed at 9 different relative humidities over the whole range; this is prosentod in Figuros $6 a$ and $b$. The dielectric constent $t^{\prime} 2$ is expressed in terms of the moasured capacitance, $\Delta C=\gamma\left(C_{0}+\epsilon_{2}^{\prime} C_{g}\right)$, and the dielectric loss in terms of the a-c. conductance $G=w \mathrm{Cg} \epsilon{ }^{\prime \prime} 2$, the symbols having the sigaificance stated oarlier.

As expected, the dispersion region is shifted to lower temperatures by an incroase in relative humidity. The maximm in the loss curvo bocomes an infloction point somewhere in the range 45 to $65 \% \mathrm{R} . \mathrm{H}$., and finally disappears completely, so that the curve assumes an exponential form (Figuro 6b). Associatod with this is a marked incroase in the slope of the dielectric constant curve, the effect being more pronounced at higher tomperaturos.

In fact, at 97 and $100 \% \mathrm{R} \cdot \mathrm{H}$. the form of this curve is that of two straight lines moeting at a point. One might be tempted to assumo that these points of intersection roprosent a phase transition of the adsorbod water from ice to water. In such a case one would expect the intersection to correspond to a higher temperature with increase in relative humidity. Since the opposite is, in faot, the case, one must sook elsewhere for an interpretation of the phenomenon. If one assumes the sorption process to be one of solution (see Introduction) and assumes as well the validity of the Clausius-Clapeyron equation, then the ice point for adsorbed water ocours below the temperature range of investigation at relative humiditios bolow $45 \%$, the region of major interest in this 
work (61). In this rogion then one would not expect the rosults to be complicated by the occurrence of a phase transition of this nature.

If it is assumed that the fractional $d-c .108 s$ is the same for paper as for the compound dielectric studied hore it is impossible to oxplain the high tomporature rise in the loss curve in terms of ionic oonductanco. An approciablo d-c. contribution to the loss (less than $1 \frac{1}{2} \%$ of tho total) appoars only at a R.H. of $97 \%$, while the high temperature increase in loss is observed already at $65 \% \mathrm{R} . \mathrm{H}$. Resolution of this problem on the basis of high temperature dispersion was likewise impossible in the present work, since the experimontal arrangement ruled out performance of the necessary measurements at temperatures higher than the range investigated.

It was interesting to dotermino exporimentally whether tho shift in the position of the dispersion region was function of molsture content or of rolative humidity. Results on paper conditioned at $45 \%$ R.H. by both adsorption and desorption are presented in Figures $7 \mathrm{a}$ and $\mathrm{b}$. It is apparent that the results are not function of relative humidity 2lone.

The desorption curves corrospond to a higher moisture content then those for adsorption, this being apparent from the increased dielectric constant and loss as woll as the disappoarsnce of the loss maximum. This points to the moisture oontent as the appropriate variablo to bo observed in the study of the disporsion region shift. This is in agrooment with the fact that the d-c. resistance of collulose likewise depends directly on its moisture content (46). 
$-43-$

FIGURE 6

a) Effeot of adsorbed wator on the dielectric constant of papor at $1 \mathrm{Mc}$.

b) Effect of adsorbed water on the dielectric loss of paper at I Mo. 


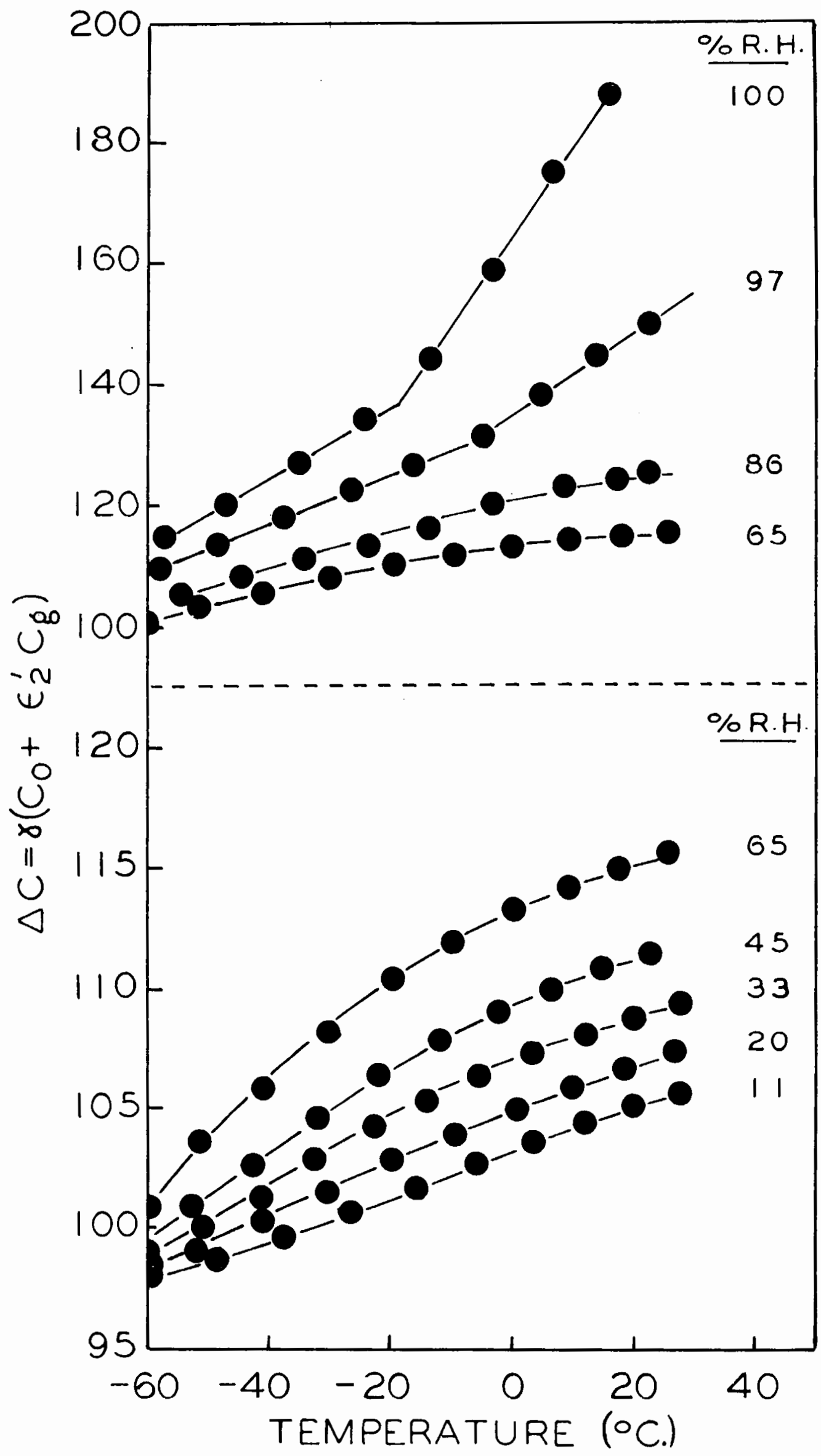


The results reviewed above represent the preliminary stage of this work and in minor respocts are slightly in orror. For exomplo, all the dielectric runs were started at the low temperature end of the range investigated. The dieloctric properties obtained in this way wore considerably lower at the low temporatures then those obtained by the improvod proceduro described earlier, and the effect was most marked at the highest moisture content. This proved to rosult from condensation of water from the paper on to the walls of the cell as it was immersed in the bath, and yielded spurious results. However, the position of the loss maximum was unaffooted by this offoct, since, at the froquency of 1 Mc. omployed at that time, the temperature of maximum loss was presumably high onough for the paper already to have come to oquilibrium with the moisture in the cell by the time the maximum in the loss curre was attained.

\section{2) Results}

The water sorption isotherm at $25^{\circ} \mathrm{C}$. of the paper used in this work is shown in Table III and Figure 8. The adsorption branch lies a littlo above the corresponding curve of Wahbe (64) for standard cellulose at $30^{\circ} \mathrm{C}$. Removal of the residual of $0.4 \%$ (seo Experimental) from the samplo of paper used in this work would make this difference moro obvious. This is a good chock on the method used here for determining sorption. One would expect the same sorption isothorm in both cases, since the water uptake of cellulose has beon shown to be a function of the fraction of amorphous substance, which is the same for 0.11 forms of native cellulose (33). 
a) Bffect of sorption hysteresis on the dielectric oonstant at 1 Mo. of papor conditionod at a relativo humidity of $45 \%$.

b) Effect of sorption hysteresis on the dielectric loss at

1 Mc. of paper conditioned at a relative humidity of $45 \%$. 


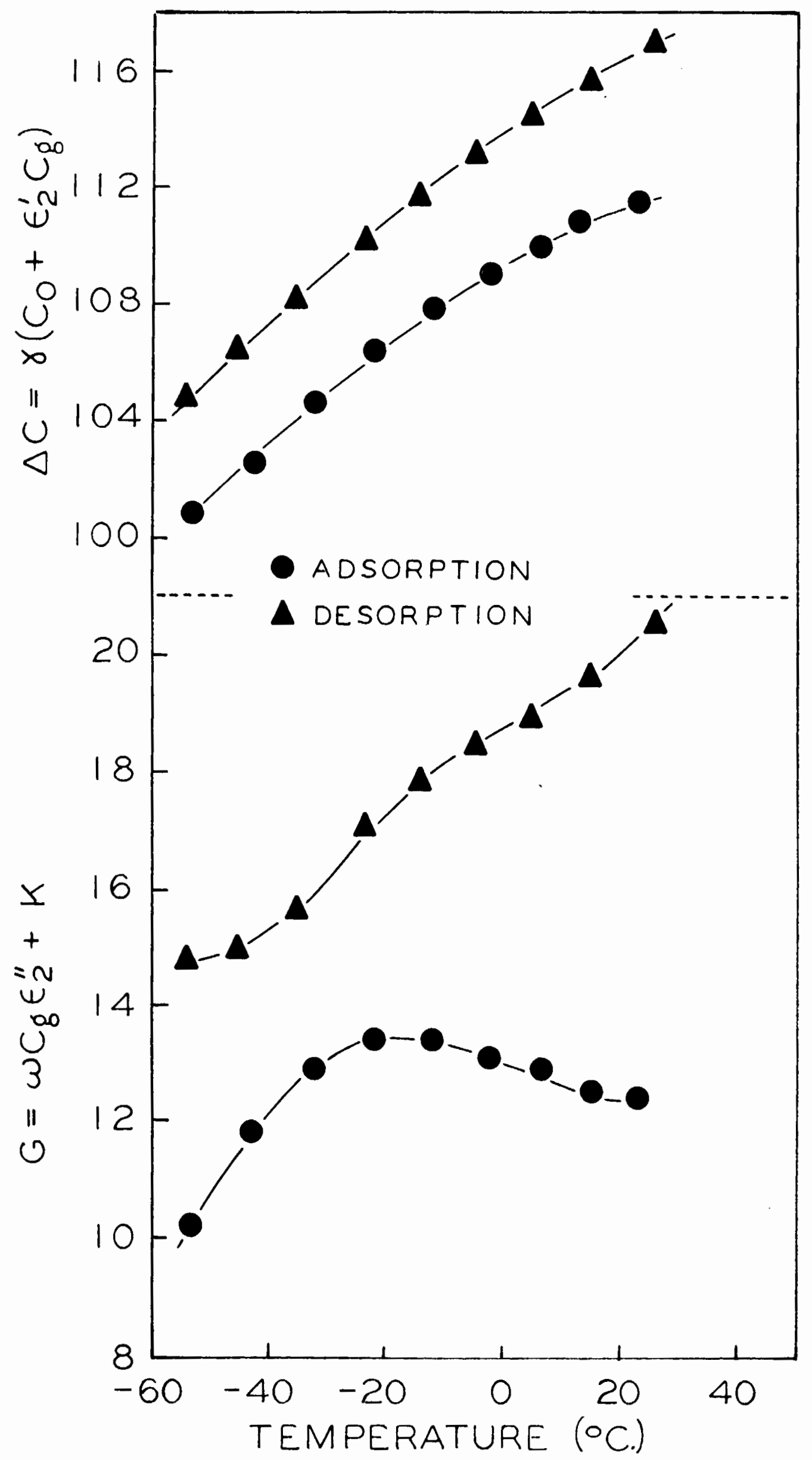


TABLE III

SORPTION OF WATER AT $25.0^{\circ} \mathrm{C}$

\begin{tabular}{ll}
\hline Re1. Vap. Pressure & $\begin{array}{c}\text { Water Sorbed } \\
\text { per cont of Dry Woight }\end{array}$ \\
\hline Adsorption & \\
\hline 0.0 & $0.0_{0}$ \\
10.9 & $2.2_{5}$ \\
24.4 & $3.4_{4}$ \\
34.4 & $4.0_{2}$ \\
46.6 & 5.34 \\
58.0 & 6.58 \\
95.8 & 17.67 \\
\hline 52.1 & $6.6_{9}$ \\
\hline 42.8 & $0.0_{0}$ \\
\hline
\end{tabular}


$-47-$

FIGURE 8

Water sorption isotherm of paper at $25.0^{\circ} \mathrm{C}$. 


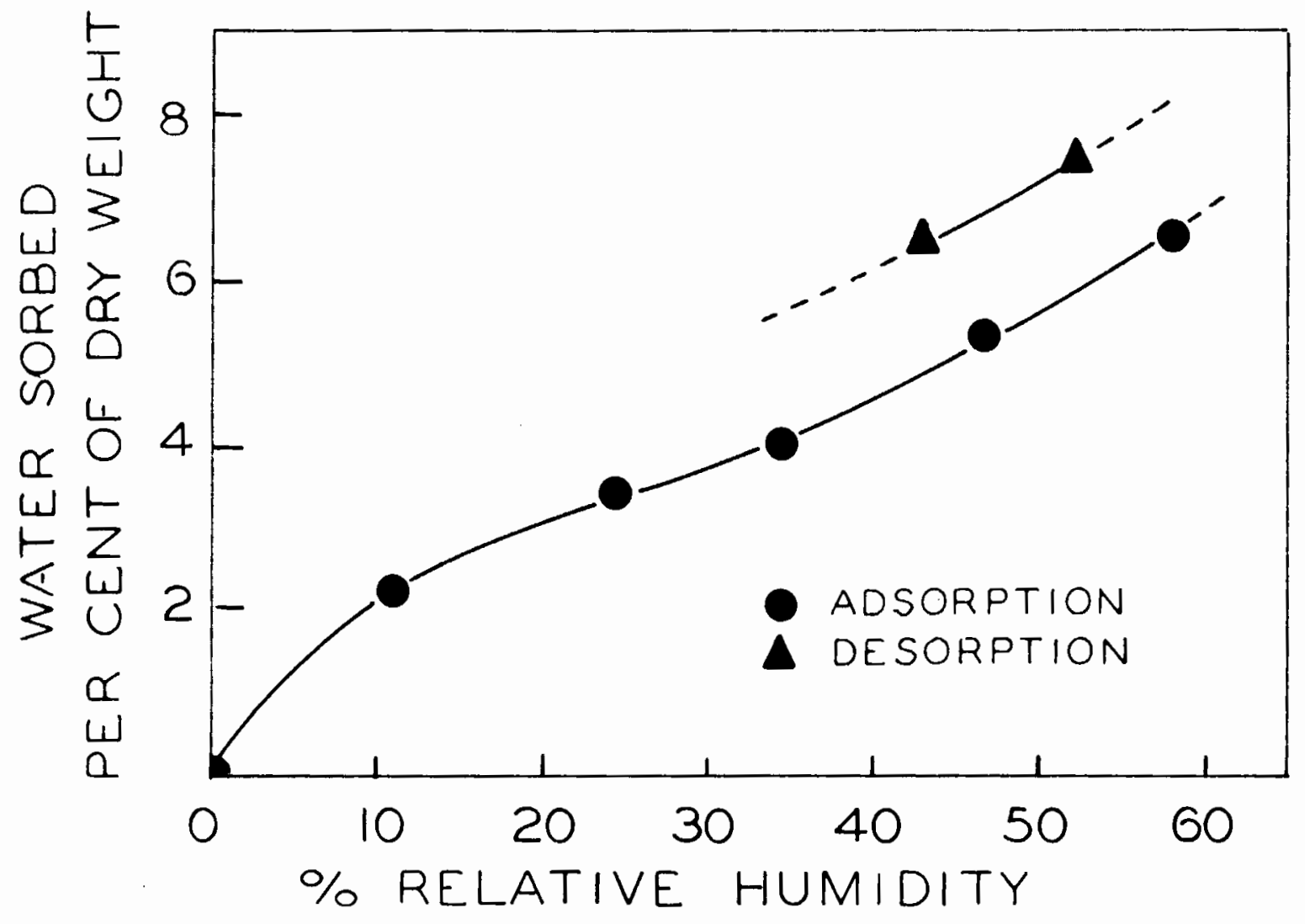


The moasured oloctrical values are oxpressed in torms of the dielectric constant and loss, $E^{\prime} 2$ and $\epsilon^{\prime \prime} 2$, of the multiplo layors of papor as arranged in the dielectric coll. $\epsilon^{\prime} 2$ is oquivalont to the term "dielectric ralue" employed by Tausz and Rum (59) and Brown (7). The expression of $t^{\prime} 2$ and $t^{\prime \prime} 2$ in terms of the corresponding values for the paper as woll as the collulose fibre itself will be discussed later. Results were obtained for water contents over the range 0 to 5.3\% at frequencies from 30 te $1000 \mathrm{KC}$. These are presented as function

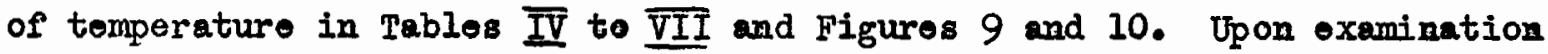
of the data cortain salient foatures are observed at once.

The temperature coefficient of $\epsilon^{\prime} 2$ is overywhere positive. At the same time absorption regions occur at the temperatures $T_{m}$ whore $\epsilon^{\prime \prime} 2$ passes through a maximum, $\left(\epsilon^{\prime \prime} 2\right)_{\max }$ At a particular moisture content, a deorease in froquenoy causes a shift of $T_{m}$ to lower tomporatures, as woll as a corresponding increase in $\epsilon^{\prime} 2$ at a particular temperature. These effocts of varying frequency are shown for dry paper in Figure 11, and are qualitative indications of dieloctric reloxation due to dipole orientation according to Dobyo thoory (13).

The presence of moisture in the paper produced interesting variations in the data. First of all one notes the increase in $\epsilon_{2}$ often observed proviously $(3,7,14,59,61)$. This follows logically from the high static dieloctric constant of water, 80 , comparod with 6 for collulose. In agreement with Ve1th the effect is more pronounced at the higher temperatures. This is no doubt a reflection of the presumption that the maximum effect is observed in the ease of the static dielectric 


\section{TABLF IV}

Dielectric Dispersion of Dry Paper at 1000, 550, 100, 30 and $100 \mathrm{Kc}$.

\begin{tabular}{|c|c|c|c|c|c|c|c|c|c|c|c|c|c|c|}
\hline \multicolumn{3}{|c|}{$1000 \mathrm{Ko}}$. & \multicolumn{3}{|c|}{$550 \mathrm{Kc}}$. & \multicolumn{3}{|c|}{$100 \mathrm{Kc}$} & \multicolumn{3}{|c|}{$30 \mathrm{Kc}}$. & \multicolumn{3}{|c|}{$10 \mathrm{Kc}$} \\
\hline$\epsilon_{2}^{\prime}$ & $\epsilon^{\prime \prime} 2$ & Tomp. & $\epsilon^{\prime} 2$ & $\epsilon^{\prime \prime} 2$ & Tomp. & $\epsilon^{\prime} 2$ & $\epsilon^{\prime \prime} 2$ & Tomp. & $\epsilon^{\prime} 2$ & $\epsilon^{\prime \prime} 2$ & Tomp. & $\epsilon_{2}^{\prime}$ & $\epsilon^{\prime \prime} 2$ & Tomp. \\
\hline 1.322 & .0154 & 26.5 & 1.266 & .0089 & -56.0 & 1.297 & .0082 & -55.3 & 1.346 & .0047 & 26.2 & 1.297 & .0108 & -55.4 \\
\hline 1.310 & .0160 & 14.6 & 1.277 & .0106 & -42.8 & 1.286 & .0097 & -42.1 & 1.341 & .0059 & $14 \cdot 3$ & 1.309 & .0111 & -42.7 \\
\hline 1.301 & .0160 & 4.8 & 1.286 & .0120 & -31.6 & 1.297 & .0107 & -31.3 & 1.333 & .0071 & 2.6 & 1.319 & .0102 & -31.4 \\
\hline 1.291 & .0152 & $-7 \cdot 7$ & 1.295 & .0134 & -19.8 & 1.307 & .0109 & -20.3 & 1.326 & .0090 & -9.2 & 1.326 & .0089 & -20.5 \\
\hline 1.281 & .0140 & -19.4 & 1.304 & .0143 & $-7 \cdot 3$ & 1.318 & .0103 & $-7 \cdot 7$ & 1.318 & .0110 & -21.3 & 1.333 & .0076 & -8.3 \\
\hline 1.274 & .0124 & -30.6 & 1.313 & .0144 & $4 \cdot 3$ & 1.325 & .0093 & 2.5 & 1.307 & .0114 & -32.6 & 1.341 & .0063 & 4.2 \\
\hline 1.264 & .0105 & -42.9 & 1.322 & .0138 & 14.8 & 1.333 & .0077 & 12.7 & 1.298 & .0110 & -43.4 & 1.346 & .0043 & 15.4 \\
\hline 1.257 & .0084 & -56.5 & 1.331 & .0125 & 26.4 & 1.339 & .0063 & 22.6 & 1.286 & .0102 & $-55 \cdot 7$ & 1.352 & .0036 & 25.7 \\
\hline
\end{tabular}




\section{TABLE V}

Dieloctrio Dispersion of Paper containing $3.3 \%$ adsorbed water at $1000,550,100,30$ and 10 Kc.

\begin{tabular}{|c|c|c|c|c|c|c|c|c|c|c|c|c|c|c|}
\hline \multicolumn{3}{|c|}{$1000 \mathrm{Kc}$} & \multicolumn{3}{|c|}{$550 \mathrm{Kc}}$. & \multicolumn{3}{|c|}{$100 \mathrm{Kc}$} & \multicolumn{3}{|c|}{$30 \mathrm{Kc}}$. & \multicolumn{3}{|c|}{$10 \mathrm{Kc}$} \\
\hline$\epsilon_{2}^{\prime}$ & $\epsilon^{\prime \prime} 2$ & Tomp. & $\epsilon_{2}^{\prime}$ & $\epsilon^{\prime} \dot{2}$ & Tomp. & $t^{\prime} 2$ & $\epsilon^{\prime \prime} 2$ & Temp. & $\epsilon_{2}^{\prime}$ & $\epsilon^{\prime \prime} 2$ & Temp. & $\epsilon^{\prime} 2$ & $\epsilon^{\prime \prime} 2$ & Tomp. \\
\hline 1.399 & .0178 & 25.6 & 1.304 & .0149 & $-54 \cdot 5$ & 1.321 & .0139 & -55.6 & 1.435 & .0103 & 25.2 & 1.352 & .0154 & -55.4 \\
\hline 1.387 & .0197 & 13.7 & 1.318 & .0177 & -42.7 & 1.338 & .0153 & -42.9 & 1.428 & .0099 & 13.9 & 1.369 & .0149 & -43.4 \\
\hline 1.372 & .0211 & 2.5 & 1.335 & .0194 & -30.9 & 1.358 & .0157 & -31.8 & 1.418 & .0107 & 2.8 & 1.387 & .0134 & -31.5 \\
\hline 1.362 & .0215 & -5.2 & 1.353 & .0205 & -19.2 & 1.373 & .0247 & -21.1 & 1.409 & .0123 & -8.2 & 1.402 & .0117 & -20.3 \\
\hline 1.352 & .0218 & -13.6 & 1.370 & .0201 & -7.8 & 1.388 & .0135 & -10.0 & 1.397 & .0138 & -18.6 & 1.412 & .0105 & -9.6 \\
\hline 1.342 & .0213 & -20.7 & 1.384 & .0186 & 3.2 & 1.400 & .0118 & 0.5 & 1.381 & .0154 & -30.8 & 1.422 & .0099 & 0.8 \\
\hline 1.328 & .0204 & -31.6 & 1.399 & .0166 & 14.0 & 1.411 & .0102 & 10.7 & 1.362 & .0169 & -43.6 & 1.429 & .0094 & 11.6 \\
\hline 1.312 & .0178 & -43.9 & 1.407 & .0151 & $24 \cdot 3$ & 1.418 & .0093 & 19.4 & 1.341 & .0165 & -56.0 & 1.439 & .0100 & 22.8 \\
\hline 1.294 & .0150 & -55.8 & & & & & & & & & & & & \\
\hline
\end{tabular}




\section{TABLE VI}

Dielectric Dispersion of Paper containing $4.0 \%$ ds orbed water at $1000 \mathrm{Kc}$.

\begin{tabular}{llr}
\hline \multicolumn{3}{c}{$1000 \mathrm{Kc}}$. \\
$\epsilon^{\prime} 2$ & $\epsilon^{\prime \prime 2}$ & Tomp. \\
\hline & .0202 & 20.7 \\
1.420 & .0216 & 9.0 \\
1.307 & .0227 & -0.1 \\
1.381 & .0233 & -11.1 \\
1.368 & .0233 & -19.7 \\
1.353 & .0230 & -29.5 \\
1.336 & .0217 & -41.1 \\
1.316 & .0190 & -55.7 \\
\hline
\end{tabular}




\section{TABLE VII}

Dielectric Dispersion of Paper containing $5.3 \%$ adsorbed water at $1000,100,30$ and $10 \mathrm{Kc}$.

\begin{tabular}{|c|c|c|c|c|c|c|c|c|c|c|c|}
\hline \multirow{3}{*}{$\frac{\epsilon^{\prime} 2}{1.453}$} & \multicolumn{2}{|c|}{$1000 \mathrm{Ko}}$. & \multicolumn{3}{|c|}{$100 \mathrm{Kc}$. } & \multicolumn{3}{|c|}{$30 \mathrm{Kc}}$. & \multicolumn{3}{|c|}{$10 \mathrm{Ko}}$. \\
\hline & $\epsilon^{\prime \prime} 2$ & Temp. & $t^{\prime} 2$ & $\epsilon^{\prime \prime} 2$ & Temp. & $\epsilon_{2}^{\prime}$ & $\epsilon^{\prime \prime} 2$ & Temp. & $t_{2}^{\prime}$ & $\epsilon^{\prime \prime} 2$ & emp. \\
\hline & .0234 & 20.4 & 1.363 & .0197 & -56.0 & 1.390 & .0209 & -56.5 & 1.534 & .0349 & 29.0 \\
\hline 1.444 & $.024_{1} 1$ & 10.2 & 1.391 & .0201 & -43.4 & 1.416 & .0206 & -43.6 & 1.516 & .0269 & 18.5 \\
\hline 1.427 & .0250 & -1.0 & 1.424 & .0189 & $-27 \cdot 4$ & 1.440 & .0186 & -31.0 & 1.501 & .0216 & $7 \cdot 7$ \\
\hline 1.412 & .0260 & -12.6 & 1.447 & .0169 & -11.3 & 1.459 & .0171 & -18.6 & 1.487 & .0177 & -3.1 \\
\hline 1.403 & .0262 & -22.6 & 1.462 & .0161 & -0.2 & 1.473 & .0167 & -6.9 & 1.473 & .0161 & -13.7 \\
\hline 1.373 & .0258 & -34.8 & 2.473 & .0162 & 9.4 & 1.485 & .0183 & 3.8 & 1.461 & .0156 & -24.2 \\
\hline 1.349 & .0243 & -46.4 & 1.482 & .0173 & 19.0 & 1.499 & .0203 & $14 \cdot 2$ & 1.444 & .0165 & -34.6 \\
\hline 1.332 & .0225 & -55.2 & 1.493 & .0196 & 28.4 & 1.511 & .0243 & 23.8 & 1.4214 & .0182 & -46.5 \\
\hline & & & & & & 1.521 & .0283 & 31.2 & 1.403 & .0188 & -56.3 \\
\hline
\end{tabular}


$-53-$

FIGURE 9

Dielectric disporsion at I MC., $0.55 \mathrm{Mc}$, and $100 \mathrm{Kc}$. of papor containing adsorbed water at the insoribed percontages. 

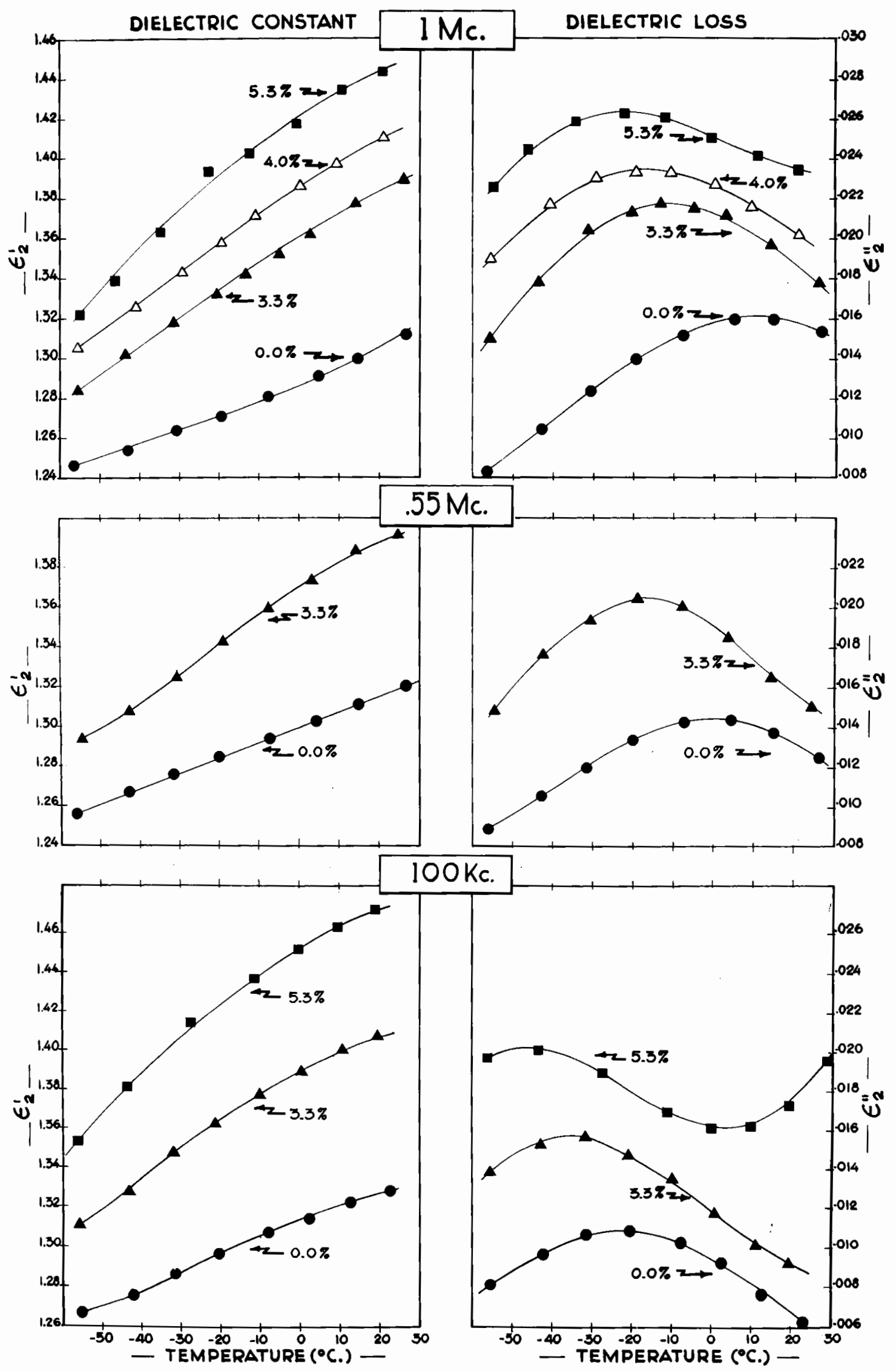


\section{$-54-$}

FIGURE 10

Dioloctric dispersion at 30 and $10 \mathrm{Kc}$. of paper containing adsorbed water at the inscribed percentages.

FIGURE 11

Dieleotric dispersion of dry paper at the inscribed frequencies. 

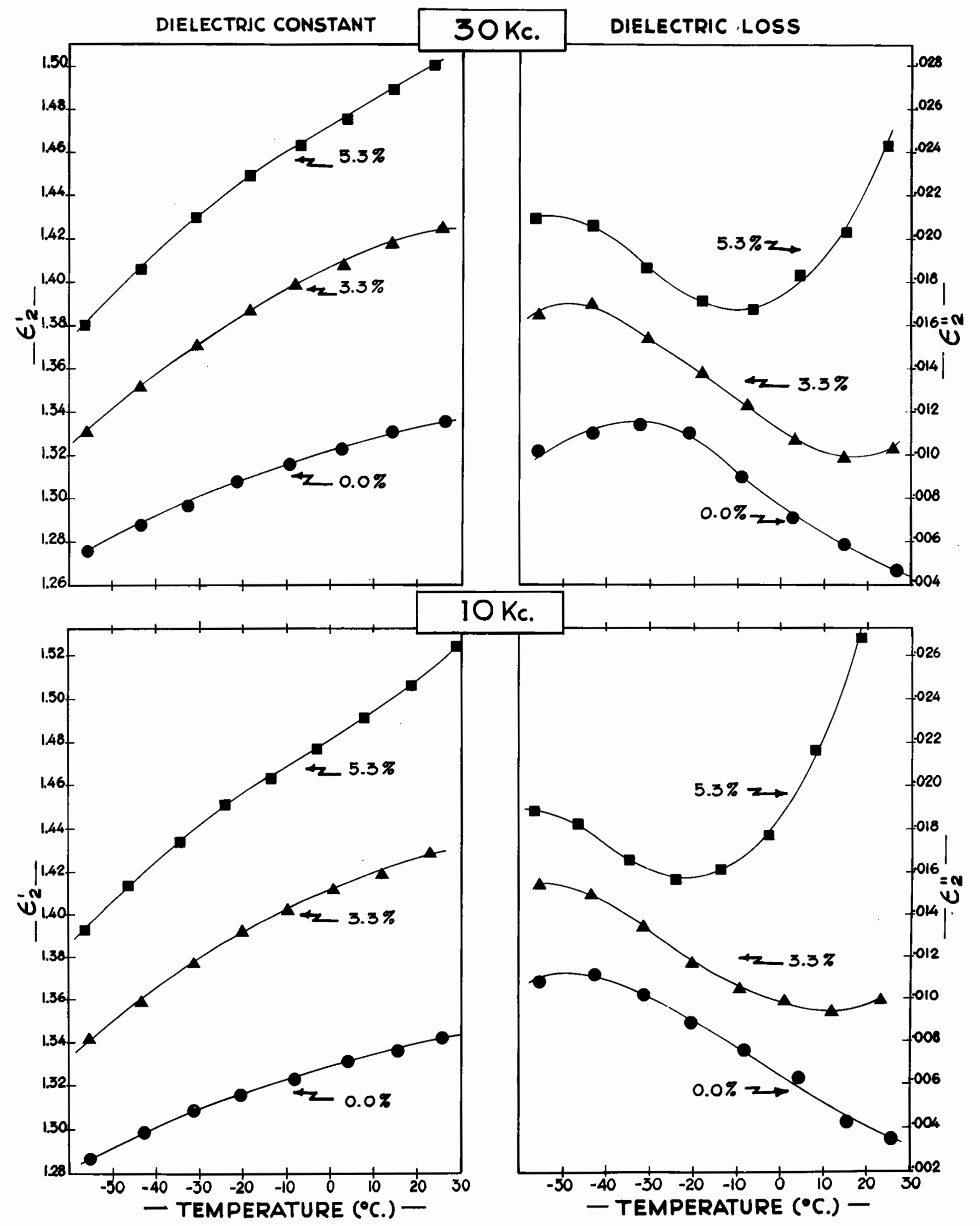


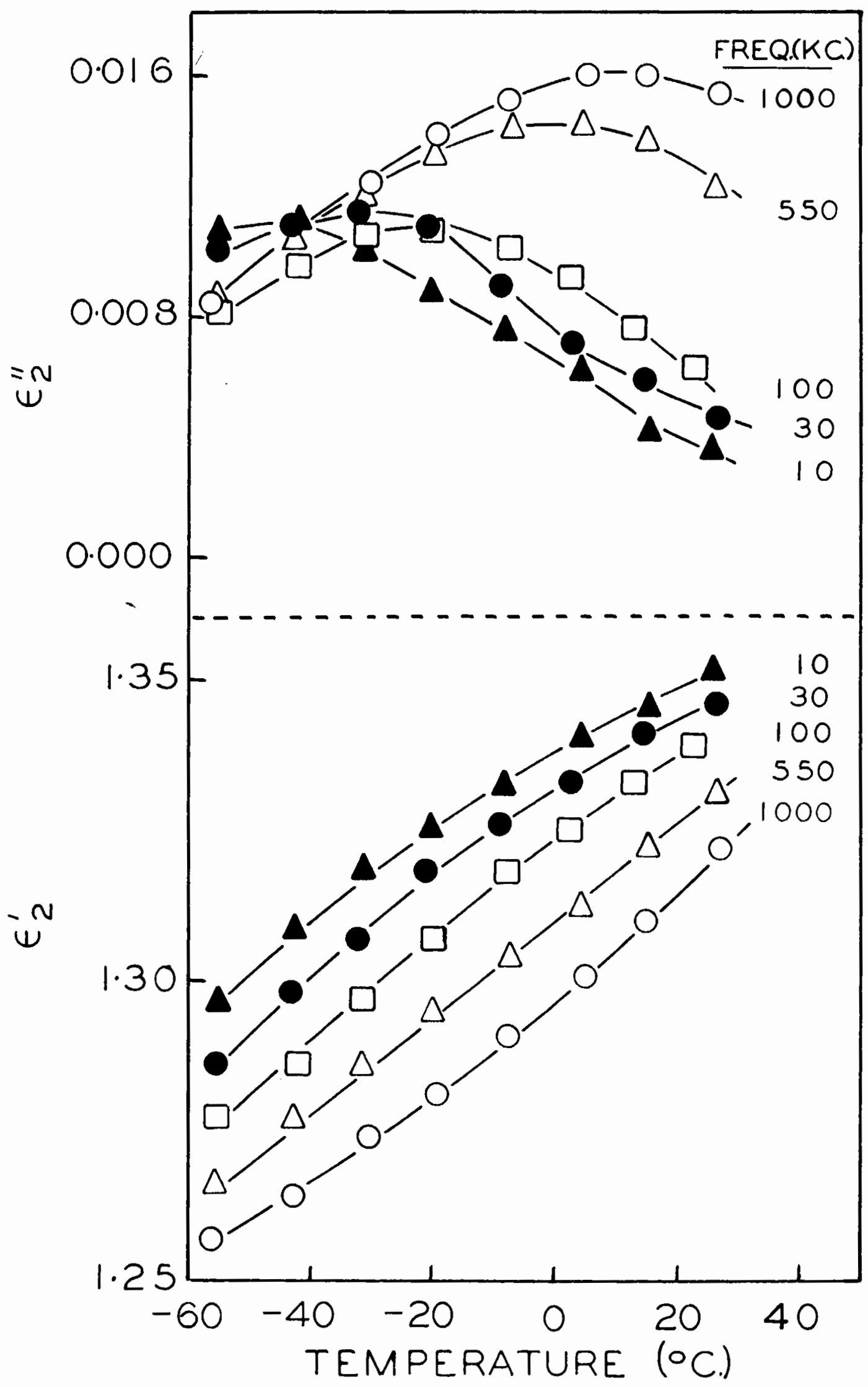


constent.

A glance at tables of rofractive index and low frequenoy dielectric constant show much smaller absolute differences in the former case than in the latter, ospecially when one is considering polar liquids like water. (The former case corresponds in general to differences in optical dielectric constant, the relationship boing

$$
\epsilon_{\infty}=n^{2}
$$

where $\mathrm{n}$ is the refractive index.) This is because dipole orientation is involved in the moasurement of $\epsilon_{0}$ but not in the moasurement of $\epsilon_{\infty}$. Thus, at temperatures below the dispersion region, the effect of water on the dielectric constant of cellulose will be slight because only $t_{\infty}$ is imvolved. At temperatures above the dispersion rogion, on the other hand, the effect is considerably greater beeause one is now concorned with ralues of $\epsilon_{0}$

At the same time moisture causes a distinct incresse in $\left(\epsilon^{\prime \prime} 2\right)_{\max }$. This is presumably a result of the increase in concentration of rotating hydroxyl groups contributed by tho water. A similar effect has beon observed in the case of terylone (48), which, like cellulose, has hydroxyl groups responsible for dielectric dispersion at characteristic frequencios and temperatures.

Probably the most significant feature of the results is the shift of $\mathrm{T}_{\mathrm{m}}$ toward lower temperatures by an increase in moisture content. This is shown in Table XVIII together with the corresponding variation in $\left(\epsilon^{*} / 2\right)_{\max }$ The effect is similar to that produced by a lowering in the 
frequency of measurement. Thus, an increase in moisture content lowers the temperature at which the rotating dipoles lose their ability to follow the fiold, signifying a decroase in the rostriction to rotation. A similar effoot, observed previously in several othor systoms (11, 22, 52), was mentioned in the Introduction. $T_{\mathrm{m}}$ for dry paper at $1 \mathrm{Mc}$. was $10^{\circ} \mathrm{C}$, compared with $16^{\circ} \mathrm{C}$. determined from Stoops' data for dry cellophone at the same frequency (57). The difference may be accounted for on the basis of the residual moisture in the dry paper as defined in this work, Stoops heving driod his somple by heating at $105^{\circ} \mathrm{C}$.

The high tomporature increase in $\epsilon$ ' '2 observed at the lower frequencios and the higher moisture contents has already been mentioned in the review of the preliminary results. The additional effect of frequency observed here still does not point to its origin as oither in ionic conductance or in aigh temperature absorption region. This is " oasily soen by reasoning as follows: If the offect has its origin in high temperature absorption due to dipole orientation, then a decrease in the frequency of measurement ought to shift the abserption region to lower temperatures. Ionic conductance as woll will manifost itself at lower temporatures the lower the frequency of measurement. Thus, unless the temperature (or frequency, or both) range of investigation is wide onough, it is difficult to distinguish betwoon the two effocts, as is the case in this work.

Mothanol and Ethanol

Results wore obtained for mothanol contents of 0.0 to $7.0 \%$ at 
100, 200, 550, and $1000 \mathrm{Kc}$, and are prosented in Tablos VIII to $\overline{\text { XIII. }}$ The offoct of mothanol on the disporsion region studied here was typically the same as observed for water, although there were significant differences in degree in some instances. E.g., the rate of increase of $\left(\epsilon^{\prime}{ }^{\prime} 2\right)_{\max }$ with vapor content at a particular frequency was significantly smaller for methanol than for water. This is to be expected on the basis of the assumption that the dispersion rogion is due to hydroxyl groups, since there are fewor groups por gram of mothanol than per gram of water. This point will be further discussed later. The same offect was observed for the rate of increase of $\epsilon_{1}$ with vapor content at a particular tomporature and frequency, the rato being higher for water than for mothenol. The high tomperature rise in $\epsilon^{\prime}{ }_{2}$ appoarod at a higher rapor content in tho case of mothanol than in that of wator. This is apparent in the loss curvos at $100 \mathrm{Kc}$. for the two cases (Figuros 9 and 12a). The comparative effoct of the two rapors in shifting the position of the dispersion rogion will be discussod in a lator soction.

In the meantime there appears in the loss curros for methanol a characteristic break botween -20 and $-10^{\circ} \mathrm{C}$. not observed at all in the curves for water. The offect becomes moro marked at higher methanol contents; this is observed in Figure 12a showing the rosults at $100 \mathrm{Kc}$. There is no corresponding break in the dielectric oonstant curves. Furthermore, the offect appears only in the cases where the runs were performod by cooling. Thus, at $200 \mathrm{Kc}$., where the runs were performed by hoating, the effect does not appear. This is likewise the caso where $T_{m}$ occurs in or noar the temperature range of break, as in the run at 550 
a) Dieloctric loss at $100 \mathrm{Kc}$. of paper containing adsorbed mothanol at the inscribed percentages.

b) Dielectric constant at $100 \mathrm{Kc}$. of paper containing adsorbed mothanol at the insoribed percentages. 


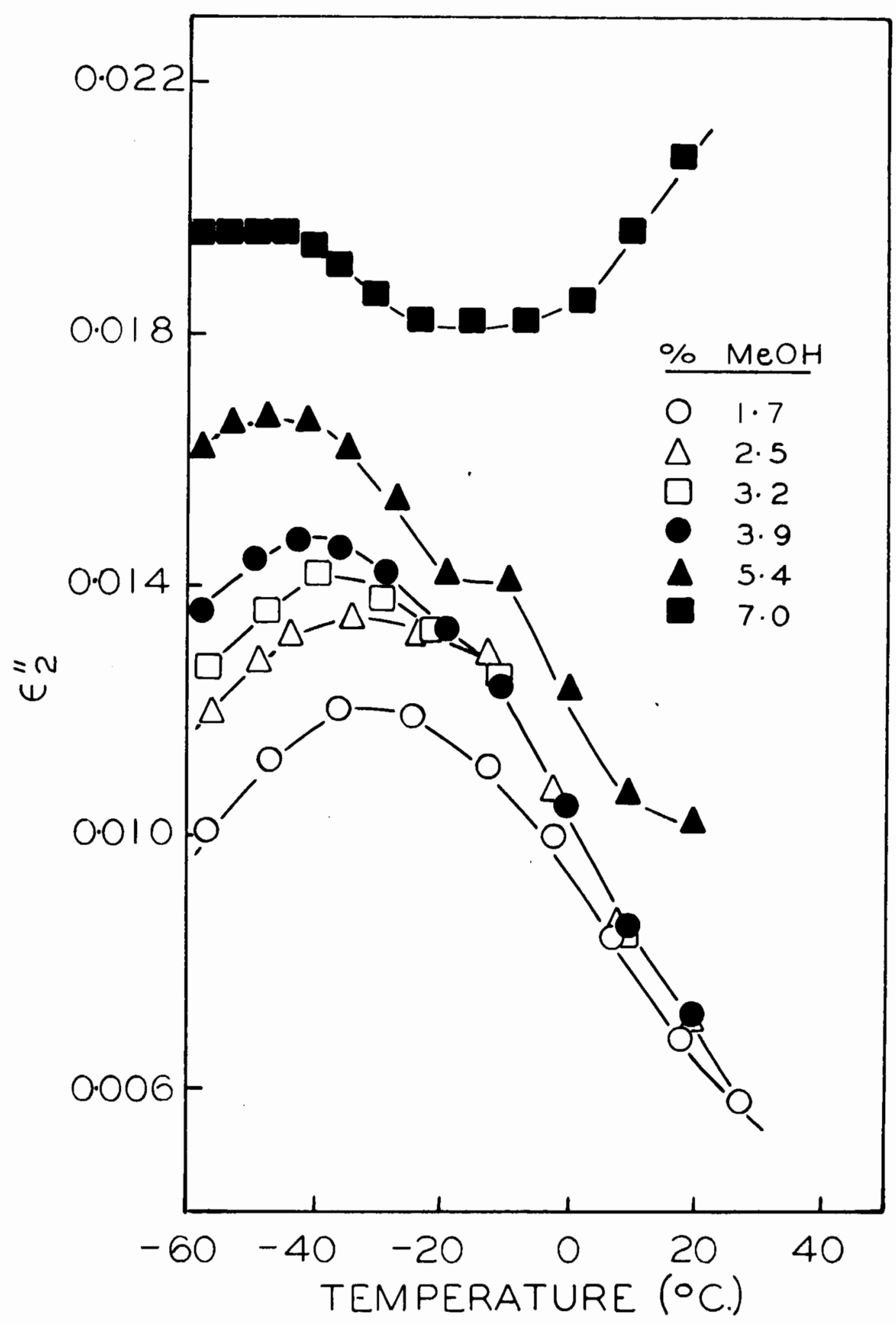




\section{TABLE VIII}

Dielectric Dispersion of Paper containing 1.7\% adsorbed mothanol at 1009, 550, 200 and $100 \mathrm{Kc}$.

\begin{tabular}{|c|c|c|c|c|c|c|c|c|c|c|c|}
\hline \multirow[b]{2}{*}{$\epsilon^{\prime} 2$} & \multicolumn{2}{|l|}{$1000 \mathrm{Kc}}$. & \multicolumn{3}{|c|}{$550 \mathrm{Ko}}$. & \multicolumn{3}{|c|}{$200 \mathrm{Kc}}$. & \multicolumn{3}{|c|}{100 Ko. } \\
\hline & $\epsilon^{\prime \prime} 2$ & Tormp. & $\epsilon^{\prime} 2$ & $\epsilon^{\prime \prime} 2$ & Temp. & $\epsilon^{\prime} 2$ & $\epsilon^{\prime \prime} 2$ & Temp. & $\epsilon^{\prime} 2$ & $\epsilon^{\prime \prime} 2$ & Torm. \\
\hline 1.272 & .0110 & -57.2 & 1.278 & .0103 & -56.5 & 1.290 & .0094 & -57.6 & 1.291 & .0101 & -57.2 \\
\hline 1.280 & .0129 & -46.4 & 1.288 & .0121 & -45.2 & 1.302 & .0105 & -46.6 & 1.302 & .0112 & $-47 \cdot 3$ \\
\hline 1.288 & .0147 & -35.2 & 1.300 & .0138 & -33.4 & 1.312 & .0118 & -35.5 & 1.312 & .0120 & -36.3 \\
\hline 1.300 & .0164 & -22.6 & 1.310 & .0151 & -21.4 & 1.324 & .0126 & -23.2 & 1.325 & .0119 & -24.5 \\
\hline 1.310 & .0178 & -10.6 & 1.322 & .0158 & -8.5 & 1.336 & .0121 & -11.4 & 1.336 & .0111 & -13.0 \\
\hline 1.322 & .0185 & 0.7 & 1.334 & .0152 & 3.2 & 1.346 & .0111 & -0.4 & 1.344 & .0100 & -2.6 \\
\hline 1.334 & .0180 & 13.3 & 1.347 & .0138 & 15.5 & 1.355 & .0095 & 9.8 & 1.352 & .0084 & \\
\hline \multirow[t]{2}{*}{1.344} & .0165 & 24.6 & 1.355 & .0125 & 25.7 & 1.361 & .0079 & 19.5 & 1.359 & .0068 & $17 \cdot 6$ \\
\hline & & & & & & 1.366 & .0069 & 28.7 & 1.365 & .0058 & 26.8 \\
\hline
\end{tabular}




\section{TABLE IX}

Diøloctric Dispersion of Paper containing 2.5\% adsorbed mothanol at 1000, 550, 200 and $100 \mathrm{Kc}$.

\begin{tabular}{|c|c|c|c|c|c|c|c|c|c|c|c|}
\hline \multicolumn{2}{|c|}{$1000 \mathrm{KC}$} & \multicolumn{4}{|c|}{$550 \mathrm{Kc}}$. & \multicolumn{3}{|c|}{$200 \mathrm{Kc}}$. & \multicolumn{3}{|c|}{$100 \mathrm{Kc}$} \\
\hline$\epsilon_{2}^{\prime}$ & $\epsilon^{\prime \prime} 2$ & Tomp. & $\epsilon_{2}^{\prime}$ & $t^{\prime \prime} 2$ & Temp. & $\epsilon_{2}^{\prime}$ & $\epsilon^{\prime \prime 2}$ & Temp. & $\epsilon_{2}^{\prime}$ & $\epsilon^{\prime \prime} 2$ & Tomp. \\
\hline 1.280 & .0122 & $-57 \cdot 2$ & 1.362 & .0134 & 19.4 & 1.300 & .0120 & -56.3 & 1.372 & .0071 & 19.3 \\
\hline 1.288 & .0144 & -46.2 & 1.352 & .0151 & 8.7 & 1.310 & .0131 & -46.2 & 1.365 & .0087 & 8.4 \\
\hline 1.300 & .0164 & -35.2 & 1.341 & .0164 & -2.0 & 1.321 & .0142 & -36.4 & 1.358 & .0108 & -2.2 \\
\hline 1.312 & .0178 & $-24 \cdot 3$ & 1.331 & .0171 & -12.6 & 1.333 & .0144 & -25.3 & 1.350 & .0129 & -12.4 \\
\hline 1.324 & .0187 & -13.1 & 1.319 & .0166 & -23.3 & 1.344 & .0139 & -14.5 & 1.338 & .0132 & -23.7 \\
\hline 1.334 & .0187 & -1.7 & 1.309 & .0154 & -34.6 & 1.355 & .0132 & -2.4 & 1.327 & .0135 & -34.0 \\
\hline 1.346 & .0185 & 8.6 & 1.299 & .0138 & -45.2 & 1.364 & .0111 & $7 \cdot 9$ & 1.316 & .0132 & -43.7 \\
\hline 1.353 & .0173 & 18.5 & 1.288 & .0116 & -58.0 & 1.371 & .0095 & 18.4 & 1.310 & .0128 & -49.0 \\
\hline 1.364 & .0162 & 28.2 & & & & 1.377 & .0082 & $27 \cdot 3$ & 1.302 & .0120 & -56.7 \\
\hline
\end{tabular}




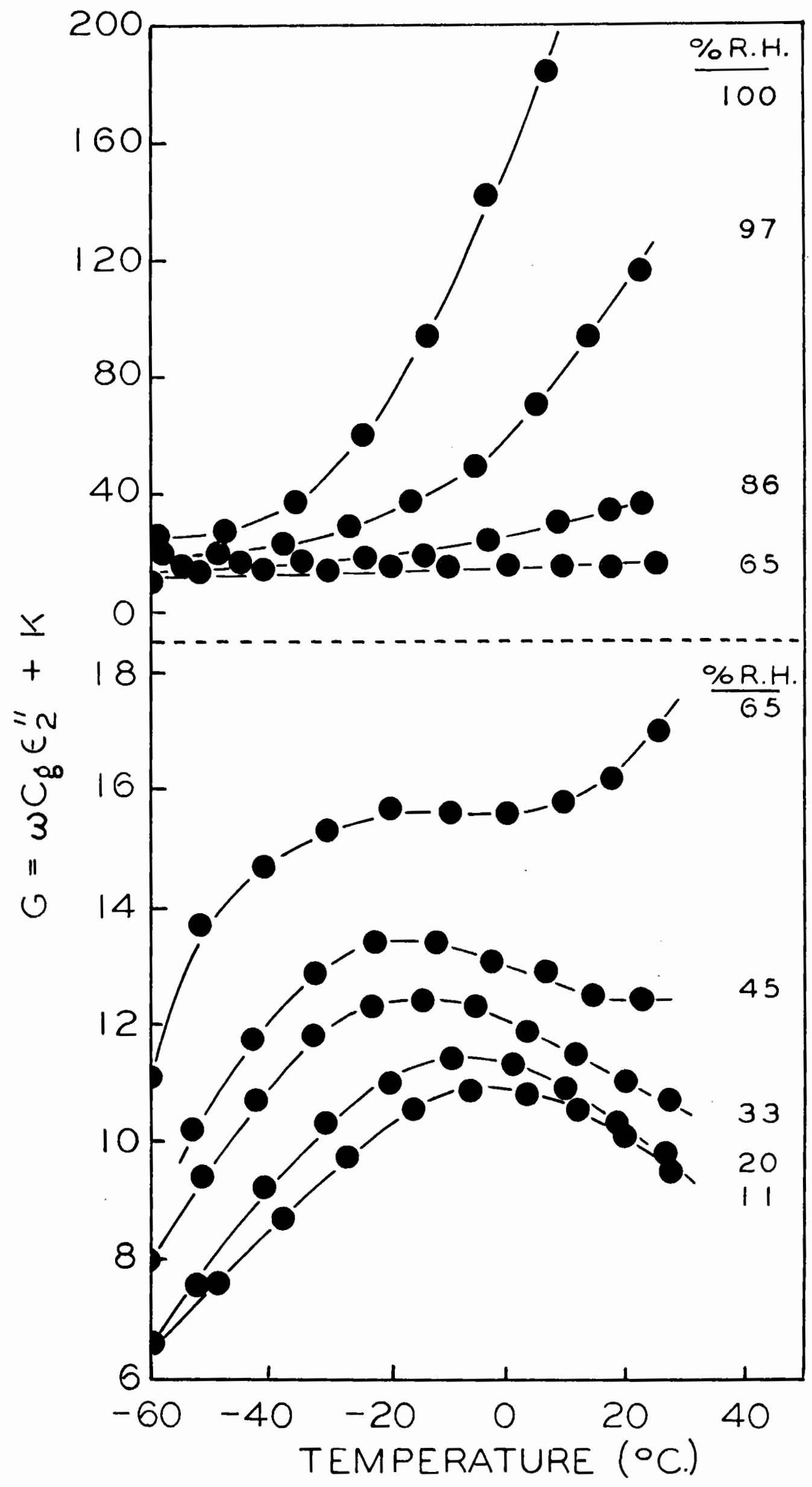




\section{TABLE $X$}

Dielectric Dispersion of Paper containing $3.2 \%$ adsorbed methenol at 1000, 550, 200 and $100 \mathrm{Kc}$.

\begin{tabular}{|c|c|c|c|c|c|c|c|c|c|c|c|}
\hline \multicolumn{3}{|c|}{$1000 \mathrm{Ko}$} & \multicolumn{3}{|c|}{$550 \mathrm{Kc}}$. & \multicolumn{3}{|c|}{$200 \mathrm{Kc}$} & \multicolumn{3}{|c|}{$100 \mathrm{Kc}$} \\
\hline$\epsilon^{\prime} 2$ & $\epsilon^{\prime \prime} 2$ & Temp • & $\epsilon^{\prime} 2$ & $\epsilon^{\prime \prime} 2$ & Temp. & $\epsilon^{\prime} 2$ & $\epsilon^{\prime \prime} 2$ & Temp. & $\epsilon_{2}^{\prime}$ & $\epsilon \prime^{\prime 2}$ & Temp \\
\hline 1.291 & .0145 & -56.4 & 1.375 & .0137 & 19.4 & 1.309 & .0128 & -56.7 & 1.384 & .0071 & 19.5 \\
\hline 1.300 & .0166 & -45.6 & 1.368 & .0153 & 9.6 & 1.324 & .0144 & -44.7 & 1.380 & .0084 & 9.2 \\
\hline 1.310 & .0180 & -35.8 & 1.358 & .0169 & -0.6 & 1.336 & .0150 & -34.8 & 1.372 & .0105 & -1.2 \\
\hline 1.322 & .0194 & -25.5 & 1.347 & .0179 & $-11 \cdot 3$ & 1.347 & .0150 & -24.4 & 1.365 & .0126 & -11.1 \\
\hline 1.334 & .0201 & -14.7 & 1.336 & .0178 & -22.2 & 1.358 & .0140 & $-14 \cdot 9$ & 1.353 & .0133 & -21.6 \\
\hline 1.347 & .0201 & -3.7 & 1.324 & .0170 & -31.6 & 1.368 & .0129 & $-4 \cdot 6$ & 1.344 & .0138 & -29.6 \\
\hline 1.358 & .0194 & 6.3 & 1.315 & .0160 & -40.1 & 1.377 & .0113 & 4.9 & 1.333 & .0142 & -39.5 \\
\hline 1.368 & .0183 & 17.2 & 1.306 & .0146 & -48.7 & 1.384 & .0097 & 16.4 & 1.322 & .0136 & $-47 \cdot 9$ \\
\hline 1.375 & .0167 & 26.7 & 1.299 & .0130 & -57.0 & 1.390 & .0079 & $27 \cdot 3$ & 1.310 & .0127 & $-57 \cdot 3$ \\
\hline
\end{tabular}




\section{TABLE XI}

Dieleotric Dispersion of Paper containing 3.9\% adsorbed methanol at 1000, 550, 200 and $100 \mathrm{Kc}$

\begin{tabular}{|c|c|c|c|c|c|c|c|c|c|c|c|}
\hline \multicolumn{3}{|c|}{$1000 \mathrm{KC}$} & \multicolumn{2}{|c|}{550 Ko. } & \multicolumn{4}{|c|}{$200 \mathrm{Kc}$} & \multicolumn{3}{|c|}{$100 \mathrm{Kc}$} \\
\hline$\epsilon^{\prime} 2$ & $\epsilon^{\prime \prime} 2$ & Temp. & $\epsilon^{\prime} 2$ & $\epsilon^{\prime \prime} 2$ & Ternp. & $\epsilon^{\prime} 2$ & $\epsilon^{\prime \prime} 2$ & Temp. & $\epsilon^{\prime} 2$ & $\epsilon^{\prime \prime} 2$ & Tomp. \\
\hline 1.297 & .0156 & -57.0 & 1.386 & $.01 / 4$ & 16.7 & 1.319 & .0136 & -56.7 & 1.399 & .0072 & 79.4 \\
\hline 1.310 & .0180 & -43.5 & .1 .377 & .0164 & 6.5 & 1.334 & .0147 & -46.2 & 1.393 & .0086 & 9.3 \\
\hline 1.321 & .0199 & -34.4 & 1.368 & .0178 & -2.0 & 1.347 & .0155 & -36.3 & 1.386 & .0105 & -0.6 \\
\hline 1.333 & .0207 & -25.2 & 1.359 & .0186 & -10.5 & 1.359 & .0153 & -26.5 & 1.378 & .0124 & -10.5 \\
\hline 1.344 & .0212 & -15.8 & 1.350 & .0190 & -18.4 & 1.369 & .0142 & $-17 \cdot 1$ & 1.369 & .0133 & -19.5 \\
\hline 1.355 & .0213 & -7.1 & 1.343 & .0188 & -26.9 & 1.381 & .0134 & -6.7 & 1.361 & .0142 & -28.9 \\
\hline 1.364 & .0208 & 1.2 & 1.333 & .0181 & -34.8 & 1.388 & .0115 & 3.5 & 1.352 & .0146 & -36.4 \\
\hline 1.371 & .0199 & 10.2 & 1.325 & .0174 & -42.5 & 1.396 & .0103 & 12.5 & 1.343 & .0147 & -43.0 \\
\hline 1.380 & .0187 & 18.7 & 1.315 & .0161 & -50.3 & 1.399 & .0087 & 20.5 & 1.334 & .0144 & -49.7 \\
\hline 1.386 & .0176 & 26.5 & 1.308 & .0147 & -58.0 & 1.403 & .0076 & 28.8 & 1.324 & .0136 & -57.8 \\
\hline
\end{tabular}




\section{TABLE XII}

Dielectric Dispersion of Paper containing 5.4\% adsorbed methanol at 1000, 550, 200 and $100 \mathrm{Kc}$.

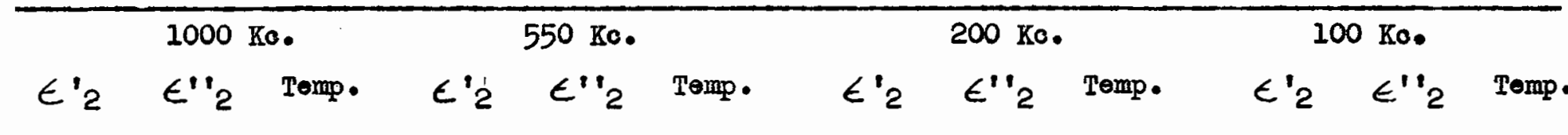

\begin{tabular}{|c|c|c|c|c|c|c|c|c|c|c|c|}
\hline 1.321 & .0191 & -56.8 & 1.418 & .0152 & 18.4 & 1.344 & .0160 & $-57 \cdot 3$ & 1.430 & .0103 & 19.5 \\
\hline 1.328 & .0204 & -49.6 & 1.408 & .0167 & 9.6 & 1.361 & .0169 & -46.7 & 1.425 & .0107 & 9.4 \\
\hline 1.339 & .0215 & -42.2 & 1.399 & .0188 & -0.2 & 1.372 & .0169 & -39.4 & 1.419 & .0124 & 0.1 \\
\hline 1.350 & .0224 & -33.6 & 1.390 & .0200 & -8.4 & 1.383 & .0165 & -31.2 & 1.414 & .0141 & -9.4 \\
\hline 1.361 & .0226 & -26.2 & 1.383 & .0210 & -15.7 & 1.392 & .0158 & -24.3 & 1.403 & .0142 & -19.3 \\
\hline 1.369 & .0226 & $-19 \cdot 7$ & 1.374 & .0211 & -22.4 & 1.403 & .0147 & -13.8 & 1.394 & .0154 & $-27 \cdot 1$ \\
\hline 1.380 & .0225 & -11.3 & 1.366 & .0212 & -28.6 & 1.412 & .0140 & $-4 \cdot 2$ & 1.384 & .0162 & -35.0 \\
\hline 1.390 & .0220 & -3.7 & 1.359 & .0212 & -35.1 & 1.419 & .0127 & 5.8 & 1.375 & .0166 & $-41 \cdot 4$ \\
\hline 1.399 & .0213 & 4.7 & 1.352 & .0207 & -42.1 & 1.425 & .0108 & 16.3 & 1.366 & .0167 & $-47 \cdot 6$ \\
\hline 1.406 & .0199 & 14.0 & 1.341 & .0199 & -49.2 & 1.428 & .0100 & 25.2 & 1.358 & .0166 & $-53 \cdot 4$ \\
\hline 1.412 & .0183 & 24.4 & 1.330 & .0188 & -58.0 & & & & 1.350 & .0162 & -58.0 \\
\hline
\end{tabular}




\section{TABLE XIII}

Dielectrie Dispersion of Paper containing $7.0 \%$ adsorbed mothanol at $1000,550,200$ and $100 \mathrm{Kc}$.

\begin{tabular}{|c|c|c|c|c|c|c|c|c|c|c|c|}
\hline \multicolumn{2}{|c|}{$1000 \mathrm{Kc}}$. & \multirow[b]{2}{*}{ Temp. } & \multicolumn{3}{|c|}{$550 \mathrm{Kc}}$. & \multicolumn{3}{|c|}{$200 \mathrm{KO}}$. & \multicolumn{3}{|c|}{$100 \mathrm{KC}}$. \\
\hline$\epsilon^{\prime} 2$ & $\epsilon_{2}^{\prime \prime}$ & & $\epsilon_{2}^{\prime}$ & $\epsilon^{\prime \prime} 2$ & Temp. & $\epsilon^{\prime} 2$ & $\epsilon^{\prime \prime} 2$ & Temp. & $\epsilon^{\prime} 2$ & $\epsilon^{\prime \prime} 2$ & Temp. \\
\hline 1.356 & .0235 & $-57 \cdot 5$ & 1.452 & .0202 & 19.7 & 1.386 & .0205 & -56.6 & 1.475 & .0208 & $17 \cdot 7$ \\
\hline 1.368 & .0246 & -49.6 & 1.444 & .0206 & 11.3 & 1.396 & .0206 & -51.1 & 1.472 & .0196 & 9.8 \\
\hline 2.380 & .0250 & $-43 \cdot 3$ & 1.437 & .0212 & 1.6 & 1.405 & .0209 & -45.4 & 1.466 & .0185 & 1.7 \\
\hline 1.388 & .0255 & $-37 \cdot 4$ & 1.428 & .0218 & -6.6 & 1.424 & .0205 & -40.0 & 1.459 & .0182 & -6.8 \\
\hline 1.400 & .0258 & -29.9 & 1.422 & .0223 & -13.6 & 1.424 & .0200 & -33.4 & 1.452 & .0182 & -15.2 \\
\hline 1.411 & .0254 & -22.4 & 1.415 & .0226 & -20.2 & 1.433 & .0195 & $-27 \cdot 2$ & 1.443 & .0182 & $-23 \cdot 3$ \\
\hline 1.421 & .0248 & -15.0 & 1.405 & .0230 & $-27 \cdot 5$ & 1.442 & .0190 & -19.7 & 1.434 & .0186 & -30.5 \\
\hline 1.430 & .0246 & -6.7 & 1.394 & .0232 & -34.7 & 1.450 & .0188 & -12.2 & 1.425 & .0191 & -36.6 \\
\hline 1.440 & .0238 & 3.5 & 1.387 & .0232 & -40.6 & 1.459 & .0188 & -2.0 & 1.419 & .0194 & -40.4 \\
\hline 1.446 & .0230 & 13.4 & 1.378 & .0229 & -46.2 & 1.465 & .0188 & 6.6 & 1.412 & .0196 & -45.3 \\
\hline 1.450 & .0222 & 22.5 & 1.372 & .0226 & -51.0 & 1.469 & .0189 & 16.4 & 1.405 & .0196 & -49.6 \\
\hline 1.452 & .0219 & $27 \cdot 9$ & 1.361 & .0219 & $-58 \cdot 3$ & 1.474 & .0196 & 26.6 & 1.399 & .0196 & -53.6 \\
\hline & & & & & & & & & 1.392 & .0196 & -58.0 \\
\hline
\end{tabular}


and $1000 \mathrm{Kc}$. (see Table $\overline{\mathrm{XIX}}$ ).

Results were obtained for othanol contents of 0.0 to $8.5 \%$ at 100, 200, 550 and $1000 \mathrm{Ko}$, and are presented in Tables XIV to XVII. After completion of the runs on paper containing $8.5 \%$ ethanol, it was decided that each subsequent run should be performed over a complete temperature cycle in order to determine the existence and the nature of the effect described above for mothanol. The results at $100 \mathrm{Kc}$. for papor containing $4.6 \%$ othanol are shown in Figure 13 and are believod to reprosent this offect in a typical fashion. It is shown to be a hysteresis of some kind occurring over the temperature range -20 to $20^{\circ} \mathrm{C}$; the broak in the curve obtained by cooling occurs in the range -20 to $-10^{\circ} \mathrm{C}$. as with methanol. Also as in the case with methanol there is no corresponding irrogularity in the $t_{2}^{\prime}$ curves. If the offect wore due to same second-order phase transition, the hysteresis could be explained, although thore is no reason why this should not also appoar in the $\epsilon^{\prime} 2$ curves. The facts point to its occurring over the same temperature range in the case of both mothanol and ethanol; this may signify some effoct which both substances heve on cellulose.

In other rospocts, the results for othanol stood in the same relation to those for methanol as the latter did to those for water. No high temperature increase in $\epsilon^{\prime \prime} 2$ was observed in any of the othanol curves. The variation of $\mathrm{T}_{m}$ and $\left(\epsilon^{\prime \prime} 2\right)_{\max }$ with vapor oontent in the throe

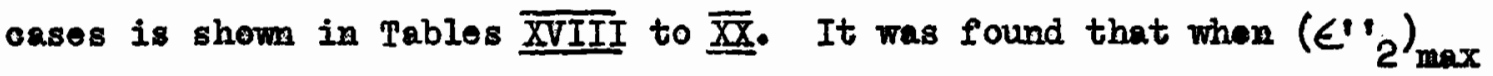
was plotted against vapor content the plots were linear within experimental orror; furthormore, there was a characteristic slope for oach 


\section{TABLE XIV}

Dielectric Dispersion of Paper containing 2.3\% adsorbed ethanol at 1000, 550, 200 and $100 \mathrm{Ko}$.

\begin{tabular}{|c|c|c|c|c|c|c|c|c|c|c|c|}
\hline \multicolumn{2}{|c|}{$1000 \mathrm{Kc}$} & \multirow[b]{2}{*}{ Temp. } & \multicolumn{3}{|c|}{$550 \mathrm{Ko}}$. & \multicolumn{3}{|c|}{$200 \mathrm{KO}}$. & \multicolumn{3}{|c|}{$100 \mathrm{Ke}$} \\
\hline$\epsilon^{\prime} 2$ & $\epsilon^{\prime \prime} 2$ & & $\epsilon^{\prime} 2$ & $\epsilon^{\prime \prime} 2$ & Temp. & $\epsilon_{2}^{\prime}$ & $\epsilon^{\prime \prime} 2$ & Temp. & $\epsilon^{\prime} 2$ & $\epsilon^{\prime \prime} 2$ & Temp. \\
\hline 1.280 & .0121 & $-57 \cdot 3$ & 1.287 & .0117 & -57.2 & 1.299 & .0115 & -56.4 & 1.302 & .0120 & -57.6 \\
\hline 1.286 & .0140 & -49.0 & 1.296 & .0131 & -49.6 & 1.308 & .0126 & -48.6 & 1.310 & .0131 & -48.8 \\
\hline 1.294 & .0159 & -40.0 & 1.302 & .0145 & -41.6 & 1.315 & .0136 & -41.2 & 1.319 & .0138 & -41.2 \\
\hline 1.303 & .0178 & -30.8 & 1.310 & .0158 & -33.4 & 1.324 & .0144 & -32.8 & 1.330 & .0139 & -32.5 \\
\hline 1.312 & .0187 & -22.3 & 1.319 & .0168 & -24.6 & 1.334 & .0144 & -24.0 & 1.340 & .0135 & -22.9 \\
\hline 1.321 & .0196 & -13.2 & 1.327 & .0172 & -16.4 & 1.343 & .0142 & -15.3 & 1.347 & .0126 & -14.6 \\
\hline 1.328 & .0199 & $-4 \cdot 5$ & 1.336 & .0172 & -8.6 & 1.352 & .0132 & -6.6 & 1.355 & .0118 & -6.6 \\
\hline 1.337 & .0194 & +3.4 & 1.344 & .0167 & 0.2 & 1.359 & .0124 & 1.9 & 1.362 & .0112 & 1.6 \\
\hline 1.346 & .0190 & 12.2 & 1.352 & .0153 & 10.3 & 1.365 & .0103 & 11.3 & 1.368 & .0096 & 10.8 \\
\hline 1.353 & .0178 & 21.3 & 1.361 & .0135 & 20.4 & 1.371 & .0090 & 20.1 & 1.372 & .0075 & 19.0 \\
\hline 1.359 & .0169 & 26.8 & & & & 1.377 & .0072 & 28.7 & 1.375 & .0064 & 25.6 \\
\hline
\end{tabular}




\section{TABLE XV}

Dielectric Dispersion of Paper containing 4.6\% adsorbed ethanol at 1000, 200 and $100 \mathrm{Kc}$.

\begin{tabular}{|c|c|c|c|c|c|c|c|c|}
\hline \multicolumn{3}{|c|}{$1000 \mathrm{Kc}$} & \multicolumn{3}{|c|}{$200 \mathrm{Kc}}$. & \multicolumn{3}{|c|}{$100 \mathrm{Ko}$} \\
\hline$\epsilon^{\prime} 2$ & $E^{\prime \prime 2}$ & Tomp. & $\epsilon^{\prime} 2$ & $\epsilon^{\prime \prime 2}$ & Temp. & $\epsilon^{\prime} 2$ & $\epsilon^{\prime \prime 2}$ & Tomp. \\
\hline 1.374 & .0177 & $23 \cdot 3$ & 1.388 & .0079 & 23.9 & 1.388 & .0059 & 25.2 \\
\hline 1.365 & .0187 & 14.8 & 1.384 & .0097 & 15.0 & 1.384 & .0074 & 16.4 \\
\hline 1.356 & .0199 & 5.6 & 1.378 & .0121 & 6.0 & 1.380 & .0092 & 8.4 \\
\hline 1.349 & .0207 & -3.4 & 1.371 & .0142 & -2.6 & 1.375 & .0122 & 0.0 \\
\hline 1.338 & .0210 & -12.3 & 1.364 & .0150 & -10.8 & 1.368 & .0133 & -8.7 \\
\hline 1.330 & .0208 & -21.2 & 1.355 & .0155 & -19.3 & 1.361 & .0134 & -16.9 \\
\hline 1.321 & .0199 & -29.3 & 1.346 & .0158 & -28.2 & 1.352 & .0142 & -25.2 \\
\hline 1.312 & .0187 & -37.4 & 1.336 & .0158 & -36.7 & 1.343 & .0150 & -33.4 \\
\hline 1.300 & .0171 & -46.3 & 1.325 & .0152 & -44.8 & 1.334 & .0151 & -41.3 \\
\hline 1.290 & .0146 & -56.7 & 1.318 & .0147 & -50.5 & 1.322 & .0147 & -49.7 \\
\hline 1.300 & .0166 & $-47 \cdot 6$ & 1.310 & .0134 & $-57 \cdot 2$ & 1.312 & .0137 & -57.4 \\
\hline
\end{tabular}


TABLE XV (Cont'd.)

Dielectric Dispersion of Paper containing 4.6\% adsorbed othanol at 1000, 200 and 100 KC.

\begin{tabular}{|c|c|c|c|c|c|c|c|c|}
\hline \multicolumn{3}{|c|}{$1000 \mathrm{Kc}}$. & \multicolumn{3}{|c|}{$200 \mathrm{Kc}$} & \multicolumn{3}{|c|}{$100 \mathrm{Kc}}$. \\
\hline$\epsilon^{\prime} 2$ & $\epsilon^{\prime \prime} 2$ & Tomp. & $\epsilon_{2}^{\prime}$ & $\epsilon^{\prime \prime} 2$ & Temp. & $\epsilon_{2}^{\prime}$ & $\epsilon^{\prime \prime} 2$ & Temp. \\
\hline 1.308 & .0183 & -40.6 & 1.322 & .0152 & $-47 \cdot 7$ & 1.322 & .0147 & -51.1 \\
\hline 1.316 & .0197 & -31.5 & 1.331 & .0160 & -39.7 & 1.333 & .0153 & -43.1 \\
\hline 1.328 & .0206 & -22.6 & 1.344 & .0163 & -29.5 & 1.341 & .0152 & -34.7 \\
\hline 1.337 & .0213 & $-14 \cdot 3$ & 1.355 & .0158 & -21.4 & 1.353 & .0146 & -25.1 \\
\hline 1.346 & .0211 & $-5 \cdot 2$ & 1.364 & .0153 & -13.2 & 1.362 & .0134 & -16.3 \\
\hline 1.355 & .0204 & 4.8 & 1.371 & .0142 & -3.6 & 1.369 & .0121 & -7.6 \\
\hline 1.364 & .0195 & 13.3 & 1.378 & .0134 & 5.4 & 1.375 & .0114 & 0.6 \\
\hline \multirow[t]{2}{*}{1.372} & .0178 & 22.6 & 1.384 & .0115 & 14.7 & 1.383 & .0106 & 10.3 \\
\hline & & & 1.390 & .0089 & 24.5 & 1.386 & .0074 & 19.8 \\
\hline
\end{tabular}


TABLE XVI

Dielectric Dispersion of Paper oontaining 6.9\% adsorbed ethenol at 1000, 200 and $100 \mathrm{KC}$.

\begin{tabular}{rrrrrrrrrr}
\hline \multicolumn{3}{c}{$1000 \mathrm{Kc}}$. & \multicolumn{3}{c}{$200 \mathrm{Kc}$} & \multicolumn{2}{c}{$100 \mathrm{Kc}$} \\
$\epsilon^{\prime} 2$ & $\epsilon^{\prime \prime} 2$ & Temp. & $\epsilon^{\prime} 2$ & $\epsilon^{\prime \prime} 2$ & Temp. & $\epsilon^{\prime} 2$ & $\epsilon^{\prime \prime 2}$ & Temp. \\
\hline 1.386 & .0173 & 25.8 & 1.402 & .0084 & 24.5 & 1.400 & .0058 & 25.6 \\
1.377 & .0190 & 16.3 & 1.397 & .0100 & 15.4 & 1.399 & .0075 & 16.8 \\
1.371 & .0208 & 7.6 & 1.393 & .0131 & 6.7 & 1.394 & .0107 & 8.3 \\
1.362 & .0218 & -1.2 & 1.386 & .0150 & -2.4 & 1.390 & .0125 & -0.8 \\
1.352 & .0221 & -10.4 & 1.378 & .0157 & -10.8 & 1.383 & .0136 & -9.7 \\
1.341 & .0220 & -18.8 & 1.369 & .0161 & -18.7 & 1.374 & .0137 & -18.8 \\
1.333 & .0215 & -26.8 & 1.359 & .0168 & -26.5 & 1.365 & .0147 & -26.5 \\
1.322 & .0208 & -34.5 & 1.350 & .0171 & -34.5 & 1.356 & .0156 & -34.6 \\
1.315 & .0199 & -42.3 & 1.340 & .0166 & -42.4 & 1.346 & .0160 & -43.3 \\
1.306 & .0180 & -50.4 & 1.328 & .0163 & -50.0 & 1.336 & .0159 & -49.7
\end{tabular}


TABLE XVI (Cont'd.)

Dielectric Dispersion of Paper containing 6.9\% adsorbed ethanol at 1000, 200 and $100 \mathrm{Ko}$.

\begin{tabular}{|c|c|c|c|c|c|c|c|c|}
\hline \multicolumn{3}{|c|}{$1000 \mathrm{Kc}$} & \multicolumn{3}{|c|}{$200 \mathrm{Kc}}$. & \multicolumn{3}{|c|}{$100 \mathrm{KC}}$. \\
\hline$\epsilon^{\prime} 2$ & $\epsilon^{\prime \prime} 2$ & Temp. & $\epsilon^{\prime} 2$ & $\epsilon^{\prime \prime} 2$ & Texp. & $\epsilon_{2}^{\prime}$ & $\epsilon^{\prime \prime} 2$ & Temp. \\
\hline 1.297 & .0164 & -57.8 & 1.318 & .0149 & -58.2 & 1.325 & .0151 & $-57 \cdot 5$ \\
\hline 1.306 & .0178 & -50.7 & 1.331 & .0165 & -50.1 & 1.336 & .0159 & -50.0 \\
\hline 1.315 & .0194 & -43.6 & 1.340 & .0171 & -43.0 & 1.343 & .0161 & -43.8 \\
\hline 1.325 & .0208 & -34.5 & 1.352 & .0174 & $-34 \cdot 7$ & 1.353 & .0162 & -36.6 \\
\hline 1.337 & .0218 & -25.2 & 1.362 & .0169 & -25.7 & 1.364 & .0154 & -28.1 \\
\hline 1.347 & .0225 & $-15 \cdot 7$ & 1.374 & .0164 & $-17 \cdot 5$ & 1.374 & .0143 & -19.7 \\
\hline 1.359 & .0222 & -5.7 & 1.383 & .0152 & $-7 \cdot 4$ & 1.383 & .0130 & -10.2 \\
\hline 1.371 & .0214 & 4.5 & 1.392 & $.01 / 4$ & 2.3 & 1.388 & .0121 & -1.7 \\
\hline 1.380 & .0199 & 15.2 & 1.397 & .0129 & 11.5 & 1.394 & .0122 & 5.8 \\
\hline \multirow[t]{2}{*}{1.387} & .0176 & 26.2 & 1.402 & .0195 & 22.5 & 1.399 & .0113 & 15.5 \\
\hline & & & & & & 1.402 & .0074 & 24.6 \\
\hline
\end{tabular}




\section{TABLE XVII}

Dielectris Dispersion of Paper containing 8.5\% adsorbed ethanol at 1000, 550, 200 and $100 \mathrm{Kc}$.

\begin{tabular}{|c|c|c|c|c|c|c|c|c|c|c|c|}
\hline \multicolumn{3}{|c|}{$1000 \mathrm{Kc}$} & \multicolumn{2}{|c|}{$550 \mathrm{Kc}$. } & \multirow[b]{2}{*}{ Temp. } & \multicolumn{2}{|c|}{$200 \mathrm{Kc}$. } & \multicolumn{4}{|c|}{$100 \mathrm{Kc}$. } \\
\hline$\epsilon_{2}^{\prime}$ & $\epsilon^{\prime \prime} 2$ & Terpp. & $\epsilon_{2}^{\prime}$ & $\epsilon^{\prime \prime}{ }_{2}$ & & $\epsilon_{2}^{\prime}$ & $\epsilon^{\prime \prime 2}$ & Temp. & $\epsilon_{2}^{\prime}$ & $\epsilon^{\prime \prime}{ }_{2}$ & Tem \\
\hline 1.409 & .0183 & 20.8 & 1.415 & .0133 & 24.3 & 1.340 & .0163 & -56.8 & 1.4214 & .0074 & \\
\hline 1.400 & .0197 & 12.4 & 1.409 & .0151 & 15.6 & 1.353 & .0176 & -49.0 & 1.421 & .0082 & \\
\hline 1.394 & .0211 & 3.9 & 1.402 & .0170 & $7 \cdot 3$ & 1.364 & .0179 & -41.8 & 1.418 & .0091 & \\
\hline 1.386 & .0222 & -4.7 & 1.394 & .0187 & -1.2 & 1.375 & .0177 & -33.6 & 1.414 & .0109 & \\
\hline 1.377 & .0230 & -12.8 & 1.387 & .0204 & -10.0 & 1.387 & .0168 & -25.0 & 1.408 & .0130 & \\
\hline 1.366 & .0230 & -20.5 & 1.377 & .0210 & -18.3 & 1.397 & .0155 & -16.4 & 1.400 & .0146 & \\
\hline 1.356 & .0228 & -29.4 & 1.366 & .0214 & -26.3 & 1.406 & .0145 & -8.2 & 1.390 & .0153 & \\
\hline 1.344 & .0220 & -37.7 & 1.356 & $.0214_{4}$ & -33.7 & 1.414 & .0129 & 0.8 & 1.380 & .0164 & \\
\hline 1.334 & .0205 & -46.7 & 1.344 & .0209 & -41.6 & 1.419 & .0108 & 10.5 & 1.369 & .0168 & \\
\hline 1.321 & .0185 & -56.3 & 1.334 & .0197 & -49.5 & 1.424 & .0095 & 19.8 & 1.358 & .0169 & \\
\hline & & & $1.324_{4}$ & .0183 & -56.8 & 1.425 & .0084 & 26.6 & 1.346 & .0165 & \\
\hline
\end{tabular}


$-72-$

FIGURE 13

Dielectric dispersion at $100 \mathrm{Ko}$. of paper containing $4.6 \%$ adsorbed ethenol. 


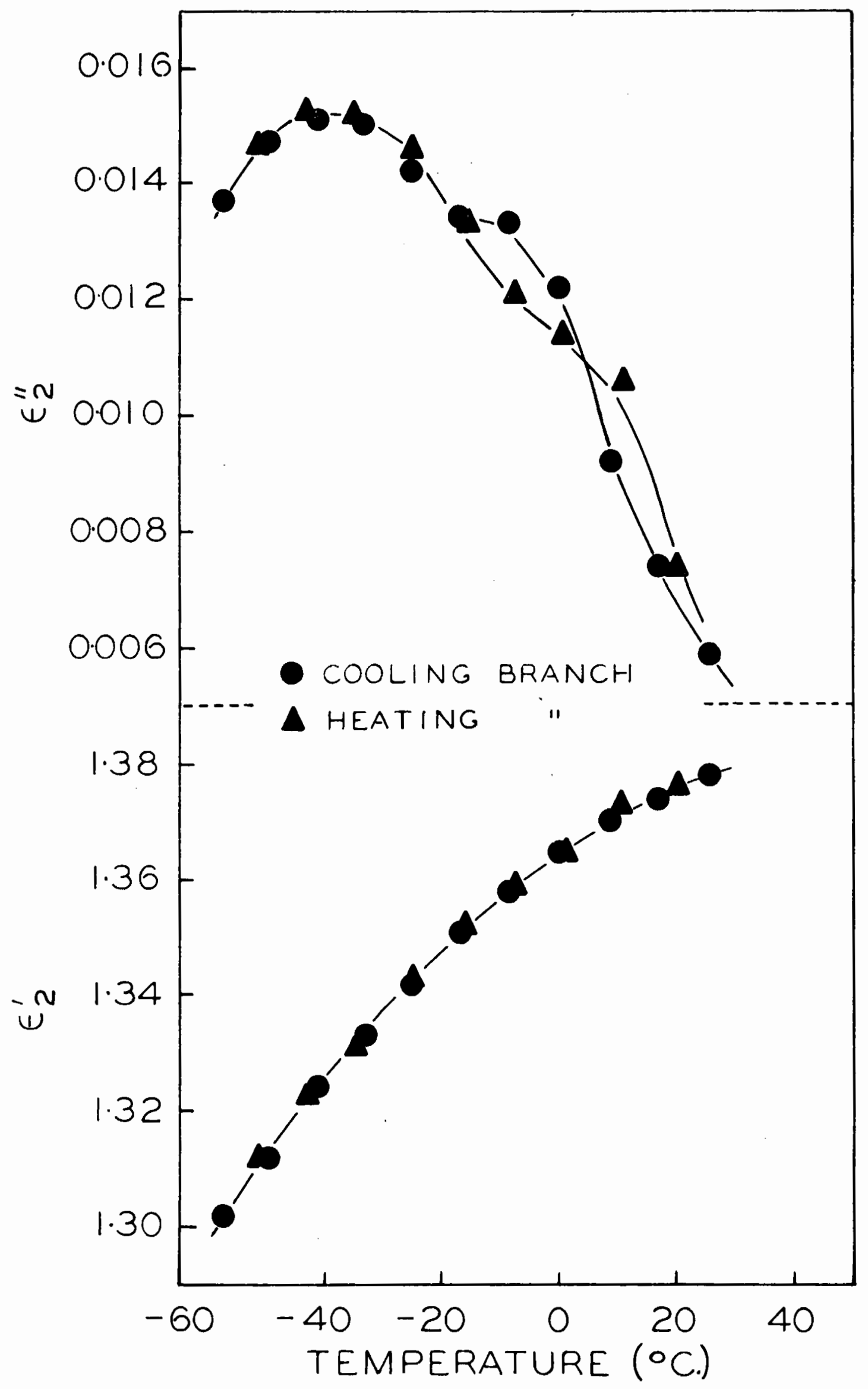


rapor, the same value being obtained at each of the frequencies used. The best lines in each case are shown in Figure 14. The slope of each line signifies the increase in loss due to one gram of added repor. Expression of this increase in terms of added hydroxyl groups ought to be a good test of the assumption that the dispersion region here studied is due to these groups. In Table XXIa the increase in loss due to one gram of hydroxyl is shown for each case. The agreement is surprising when one considers that the logical basis for comparison should be the area under the $\epsilon^{\prime \prime} 2$ curres rather than $\left.\left(t^{\prime \prime}\right)_{2}\right)_{\text {max }}$, since in all probability a distribution of relaxation times is involved. Extension of the temperature range of investigation here employed ought to make such comparison possible.

This is more readily seen by considering similar calculations made for terylene, a polyester which, like cellulose, is characterized by dispersion region attributable to hydroxyl groups (48). Terylono is normally $40 \%$ crystalline, but can be obtained as a completely amorphous material. Dielectric data were obtained for both forms in the dry as woll as in the wet state. The ovidence shows that water is absorbed by the amorphous polymer, or into the emorphous regions of the partially crystalline material, as in the case of collulose. Also, it is only in the amorphous regions that the dielectric process operates which is responsible for the losses. Although these losses are different for the two forms, one would expect the loss per gram of added water (or per hydroxyl group) to be the same. Equiralent expressions for this parameter

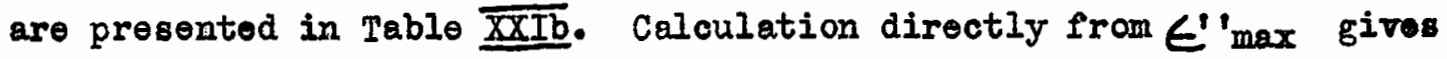


$-74-$

FIGURE 14

Effoct of vapor content on $(\epsilon " 2)_{\max }$ 


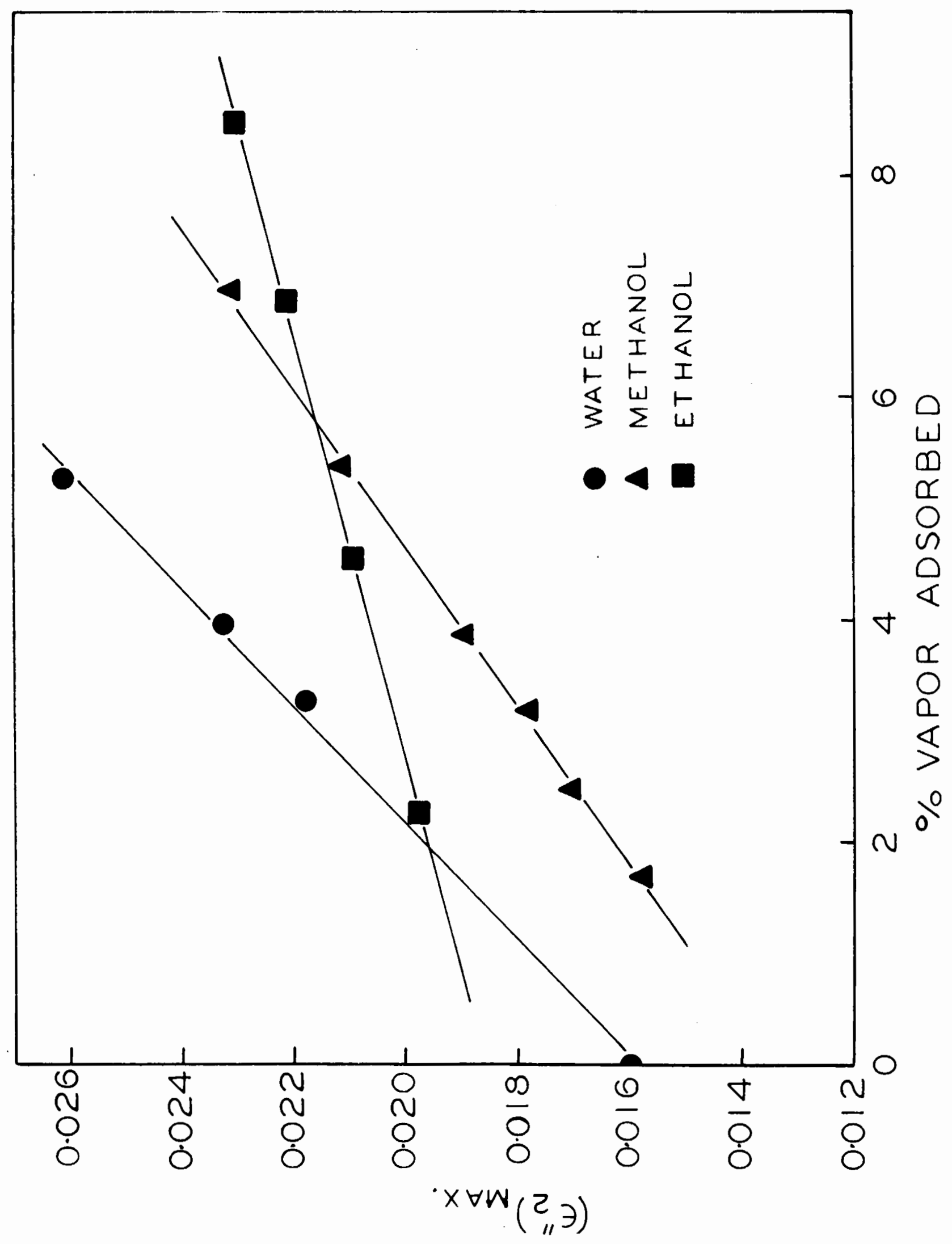


results deviating from the arerage by $5.8 \%$ while the deviation obtained by using as criterion the area under the $\epsilon^{\prime \prime}$ curve is only $3 \%$.

Sillars, as quoted by Reddish (48), found that the area under $\epsilon^{\prime \prime}-$ In $f$ curves is in the same relation to the number of dipoles and their moment whatever the distribution of relexation times. In an ideal case where a single relexation time is involved this area is $\pi \epsilon^{\prime \prime}{ }_{\max }$ so that $\epsilon^{\prime \prime}{ }_{\max }$ can be regarded as a direct moasure of the number of dipoles. However, whon there is a spread of relaxation times, this is no longer the case, and one must then resort to mosuremont of aroas. It must be kept in mind that in Tablo $\overline{X X I Q}$ the loss is expressed in terms of the compound dielectrie collulese-vaper - rapor, as defined in the Analysis of Dielectric, while in Table $\overline{\text { XXIb }}$ the less is a direct property of terylene. Comparison of the meesurements for the two polymers is therefore diffioult under these conditions, but can be attempted in an approximate manner as shown in the Discussion. 


\section{TABLE XVIII}

Variation of $T_{m}$ and $\left(\epsilon^{\prime} 2\right)_{\max }$ with amount of water adsorbed.

\begin{tabular}{|c|c|c|c|c|}
\hline $\begin{array}{l}\text { Frequenoy } \\
\text { (Kc.) }\end{array}$ & Rel. vap. press. & $\begin{array}{l}\text { Water adsorbed: per } \\
\text { cent of dry weight }\end{array}$ & $\epsilon^{\prime} \max$ & $\mathrm{T}_{\mathrm{m}}\left({ }^{\circ} \mathrm{C}\right.$ \\
\hline \multirow[t]{4}{*}{1000} & 0.0 & 0.0 & .0160 & 10 \\
\hline & 22.3 & 3.3 & .0218 & -12 \\
\hline & 32.4 & $4 \cdot 0$ & .0233 & -17 \\
\hline & 46.6 & 5.3 & .0262 & -21 \\
\hline \multirow[t]{3}{*}{550} & 0.0 & 0.0 & .0144 & 0 \\
\hline & 22.3 & $3 \cdot 3$ & .0205 & -17 \\
\hline & 46.6 & $5 \cdot 3$ & - & - \\
\hline \multirow[t]{3}{*}{100} & 0.0 & 0.0 & .0109 & -24 \\
\hline & $22 \cdot 3$ & 3.3 & .0157 & -35 \\
\hline & 46.6 & $5 \cdot 3$ & .0201 & -47 \\
\hline \multirow[t]{3}{*}{30} & 0.0 & 0.0 & .0124 & -36 \\
\hline & $22 \cdot 3$ & 3.3 & .0169 & -48 \\
\hline & 46.6 & $5 \cdot 3$ & - & - \\
\hline \multirow[t]{3}{*}{10} & 0.0 & 0.0 & .0111 & -48 \\
\hline & 22.3 & 3.3 & - & - \\
\hline & 46.6 & 5.3 & - & - \\
\hline
\end{tabular}


TABLE XIX

Variation of $\mathrm{T}_{\mathrm{m}}$ and $\left(\epsilon^{\prime}{ }^{\prime}\right)_{\max }$ with amount of methanol adsorbed

\begin{tabular}{|c|c|c|c|c|}
\hline $\begin{array}{l}\text { Frequency } \\
(\text { (Kc.) }\end{array}$ & Re1. vap. press. & $\begin{array}{l}\text { Methanol sorbediper } \\
\text { cent of dry weight }\end{array}$ & $\left(\epsilon_{2}\right)_{\text {nax }}$ & $\mathrm{T}_{\mathrm{m}}\left({ }^{\circ} \mathrm{C}_{0}\right)$ \\
\hline 1000 & $\begin{array}{r}0.0 \\
9.6 \\
19.3 \\
32.1 \\
57.1 \\
75.5\end{array}$ & $\begin{array}{l}1.7 \\
2.5 \\
3.2 \\
3.9 \\
5.4 \\
7.0\end{array}$ & $\begin{array}{l}.0185 \\
.0187 \\
.0201 \\
.0213 \\
.0226 \\
.0258\end{array}$ & $\begin{array}{r}0 \\
-7 \\
-10 \\
-13 \\
-21 \\
-28\end{array}$ \\
\hline 550 & $\begin{array}{r}0.0 \\
9.6 \\
19.3 \\
32.1 \\
57.1 \\
75.5\end{array}$ & $\begin{array}{l}1.7 \\
2.5 \\
3.2 \\
3.9 \\
5.4 \\
7.0\end{array}$ & $\begin{array}{l}.0158 \\
.0171 \\
.0179 \\
.0190 \\
.0212 \\
.0232\end{array}$ & $\begin{array}{l}-8 \\
-15 \\
-16 \\
-19 \\
-26 \\
-35\end{array}$ \\
\hline 200 & $\begin{array}{r}0.0 \\
9.6 \\
19.3 \\
32.1 \\
57.1 \\
75.5\end{array}$ & $\begin{array}{l}1.7 \\
2.5 \\
3.2 \\
3.9 \\
5.4 \\
7.0\end{array}$ & $\begin{array}{l}.0126 \\
.0144 \\
.0150 \\
.0155 \\
.0169 \\
.0209\end{array}$ & $\begin{array}{l}-20 \\
-27 \\
-31 \\
-32 \\
-41 \\
-47\end{array}$ \\
\hline 100 & $\begin{array}{r}0.0 \\
9.6 \\
19.3 \\
32.1 \\
57.1 \\
75.5\end{array}$ & $\begin{array}{l}1.7 \\
2.5 \\
3.2 \\
3.9 \\
5.4 \\
7.0\end{array}$ & $\begin{array}{r}.0120 \\
.0135 \\
.0142 \\
.0147 \\
.0167 \\
-\end{array}$ & $\begin{array}{r}-30 \\
-34 \\
-37 \\
-41 \\
-47 \\
-\end{array}$ \\
\hline
\end{tabular}


TABLE XX

Variation of $\mathrm{T}_{\mathrm{m}}$ and $\left(\epsilon^{\prime \prime} 2\right)_{\max }$ with amount of ethonol adsorbed

\begin{tabular}{|c|c|c|c|c|}
\hline $\begin{array}{l}\text { Frequency } \\
\qquad(\mathrm{KC} .)\end{array}$ & Rel. vap. press. & $\begin{array}{l}\text { Ethenol sorbed:per } \\
\text { cent of dry weight }\end{array}$ & $\left(\epsilon_{2}^{\prime}\right)_{\max }$ & $\mathbb{T}_{m}\left({ }^{0} \mathrm{C}_{\bullet}\right)$ \\
\hline 1000 & $\begin{array}{r}0.0 \\
23.7 \\
40.0 \\
65.1\end{array}$ & $\begin{array}{l}2.3 \\
4.6 \\
6.9 \\
8.5\end{array}$ & $\begin{array}{l}.0198 \\
.0210 \\
.0222 \\
.0231\end{array}$ & $\begin{array}{l}-5 \\
-12 \\
-13 \\
-21\end{array}$ \\
\hline 550 & $\begin{array}{r}0.0 \\
23.7 \\
40.0 \\
65.1\end{array}$ & $\begin{array}{l}2.3 \\
4.6 \\
6.9 \\
8.5\end{array}$ & $\begin{array}{r}.0172 \\
.0214\end{array}$ & $\begin{array}{r}-13 \\
- \\
-30\end{array}$ \\
\hline 200 & $\begin{array}{r}0.0 \\
23.7 \\
40.0 \\
65.1\end{array}$ & $\begin{array}{l}2.3 \\
4.6 \\
6.9 \\
8.5\end{array}$ & $\begin{array}{l}.0144 \\
.0160 \\
.0172 \\
.0179\end{array}$ & $\begin{array}{l}-25 \\
-32 \\
-35 \\
-40\end{array}$ \\
\hline 100 & $\begin{array}{r}0.0 \\
23.7 \\
40.0 \\
65.1\end{array}$ & $\begin{array}{l}2.3 \\
4.6 \\
6.9 \\
8.5\end{array}$ & $\begin{array}{l}.0140 \\
.0151 \\
.0161 \\
.0170\end{array}$ & $\begin{array}{l}-33 \\
-39 \\
-44 \\
-47\end{array}$ \\
\hline
\end{tabular}


TABLE XXIa

Increase in $\left(\epsilon^{\prime \prime}\right)_{\max }$ for cellulose due to the hydroxyl groups of the adsorbed repor.

\begin{tabular}{llllll}
\hline Vapor adsorbed & $\begin{array}{l}\text { Loss } \\
\text { per g. } \\
\text { vapor }\end{array}$ & $\begin{array}{l}\text { Dev } \\
\text { from } \\
\text { avg.(\%) }\end{array}$ & $\begin{array}{l}\text { Molooular } \\
\text { wt. of } \\
\text { vapor }\end{array}$ & $\begin{array}{l}\text { Loss } \\
\text { per g. } \\
\text { OH }\end{array}$ & $\begin{array}{l}\text { Der } \\
\text { from } \\
\text { avg.(\%) }\end{array}$ \\
\hline Water & .00188 & 48 & 18 & .0020 & 0 \\
Nothanol & .00140 & 10 & 32 & .0026 & 30 \\
Ethonol & .00052 & 59 & 46 & .0014 & 30 \\
\hline
\end{tabular}

TABLE XXIb

Increase in losses for terylene due to adsorbed water vapor

\begin{tabular}{|c|c|c|c|c|c|c|c|}
\hline Material & $\begin{array}{c}\% \\
\text { Ads orbed } \\
\text { water }\end{array}$ & $\begin{array}{l}\epsilon^{\prime \prime} \max \\
\text { at } \\
\mathrm{O}^{\circ} \mathrm{C} .\end{array}$ & $\begin{array}{l}\text { Area under } \\
\epsilon^{\prime \prime} \text { - Inf } \\
\text { ourre at } \\
O^{\circ} \mathrm{C} \text {. }\end{array}$ & $\begin{array}{l}\text { Change } \\
\epsilon^{\prime \prime} \max \\
\text { gm. add } \\
H_{2} \mathrm{O}\end{array}$ & $\begin{array}{l}\text { in } \\
\text { per } \\
\text { ded }\end{array}$ & $\begin{array}{l}\text { Change } \\
\text { area } \\
\text { gm. ac } \\
\mathrm{H}_{2} \mathrm{O}\end{array}$ & $\begin{array}{l}\text { o in } \\
\text { por } \\
\text { dded }\end{array}$ \\
\hline $\begin{array}{l}\text { Crystalline } \\
\text { Crystalline }\end{array}$ & 0.00 & 0.041 & $0.418\}$ & .0409 & $\begin{array}{l}\text { \% der } \\
\text { from } \\
\text { avg. }\end{array}$ & $\begin{array}{r}0.418 \\
-. \quad 18\end{array}$ & $\begin{array}{l}\text { \% dov } \\
\text { frora } \\
\text { avg. }\end{array}$ \\
\hline $\begin{array}{l}\text { Amorphous } \\
\text { Amorphous }\end{array}$ & 0.64 & 0.096 & $\left.\begin{array}{l}0.706 \\
0.958\end{array}\right\}$ & .0460 & 5.8 & .394 & 3.0 \\
\hline
\end{tabular}

Source of data (48) 
DISCUSSION OF RESULTS

A series of experiments was performed over a frequency range of 30 to $1000 \mathrm{Kc}$. and temperature range of -58 to $26^{\circ} \mathrm{C}$. The dielectric was a compound one consisting of a paper made of pure collulose containing varying amounts of adsorbed vapor, and the vapor itself at varying pressure. A dispersion region was found for dry paper oorresponding to that previously discovered for dry cellophane, a regenerated form of cellulose. It was found as woll that adsorbed water, mothanol and ethanol cause this dispersion region to be shifted in a systematic way.

\section{Analysis of Dielectric}

The arrangement in the experimental condenser was that of layers of paper alternating with layers of vapor, the layers being parallel to one sother and to the electrodes. If a cross-section of the cell is teken perpendioular to the layers, the arrangement is a spiral one as shown in Figure 15 a.

The dielectrio constant and loss of this compound dielectric are referred to as $t_{2}^{\prime}$ and $\epsilon^{\prime \prime}{ }^{\prime}$, respectivoly. Following is a method of caloulating from these measured values the corresponding ones $\epsilon_{1}$ and $\epsilon^{\prime \prime} I$ for the paper itself, and finally, $\epsilon$ ' for pure native cellulose. For the calculation of $\epsilon^{\prime}{ }_{1}$ and $\epsilon^{\prime \prime}{ }_{1}$ a model was chosen of $n$ layers of paper alternating with $(n+1)$ layers of rapor, as shown in Figure 15b. $c_{1}$ is the capacitance of the vapor layer (assumed to be a pure capacitance), whilo $C_{2}$ and $G_{2}$ are the parallel capacitance and con- 
ductance for a single layer of peper, $C_{p}$ and $G_{p}$ represent the measured capacitance and conductance. It is assumed that $G^{2} 2 \ll \Delta^{2} c^{2} 2$, so that all powers of $G_{2}$ higher then the square can be neglected. An equivalent condition is that $\left(\epsilon_{1}^{\prime}\right)^{2} \ll\left(\epsilon_{2}^{\prime}\right)^{2}$. This is true to within less than $0.1 \%$ for the data of Table $\overline{X X I I}$, and consequently for the major part of this work.

The admittence of the model, $Y$, can be shown to be giren by:

$$
Y^{2}=w^{2} c_{2}^{2} \frac{c_{1}^{2}}{\left[n c_{1}+(n+1) c_{2}\right]^{2}}+c_{2}^{2} \frac{n c_{1}^{3}}{\left[n c_{1}+(n+1) c_{2}\right]^{3}}
$$

Wheree:

$$
\begin{aligned}
& c_{p} \quad=c_{2}\left[\frac{c_{1}}{n c_{1}+(n+1) c_{2}}\right] \\
& G_{p}=G_{2}\left[\frac{n c_{1}^{3}}{\left(n c_{1}+(n+1) c_{2}\right)^{3}}\right]^{\frac{1}{2}}
\end{aligned}
$$

These equations are expressed in terms of dielectric constants and 10sses, thus ?

$$
\begin{aligned}
& \epsilon_{2}^{\prime}=\epsilon_{1}^{\prime}\left[\frac{1}{v_{2} / v+\epsilon_{1}^{\prime} v_{1 / N}}\right] \\
& \epsilon^{\prime \prime} 2=\epsilon^{\prime \prime}{ }_{1}\left(\frac{v_{2}}{V}\right)^{\frac{1}{2}}\left[\frac{1}{v_{2} / v+\epsilon_{1}^{\prime} v_{1} / N}\right]^{3 / 2}
\end{aligned}
$$

Combining (1) and (2),

$$
\epsilon^{\prime \prime}=\epsilon^{\prime \prime}\left(\frac{v_{2}}{v}\right)^{\frac{1}{2}}\left(\frac{\epsilon^{\prime} 2}{\epsilon_{1}^{\prime}}\right)^{3 / 2}
$$


$-82-$

FIGURE 15

Model for dielectric.

a) Aotual arrangement.

b) Thoorotical model. 
$\mathrm{V}_{2} / N$ represents the volume fraction of paper in the coll and $V_{1} / N=$ $1-V_{2} / v$. Equation ( 1 ) is the samo as that obtained by Argue and Mass for a similar model (2).

In Table $\overline{X X I I}$ are given values of $\epsilon_{1}$ and $\epsilon^{\prime \prime} 1$ calculated from the experimentsl results at $1 \mathrm{Mc}$. for paper containing 0 and 5.3 percent adsorbed water. The loss data aro plotted in Figure 16. It is apparent that the position of the absorption region is affected very little by the transformation of the properties of the compound dielectric to those of the paper itsolf. In the case of the results for $5.3 \%$ water, the value of $\mathrm{V}_{2} / \mathrm{V}$ was determined as 0.635 , on the assumption that the volumes of cellulose and water are additive (4), and further assuming that the changes in rolume of the fibres were duplicated in similar changes for the paper. All subsequent values of $V_{2} / V$ reported were calculated on the basis of this assumption. Because of the low coefficients of thermal exponsion of collulose (19), $\nabla_{2} / v$ varied over the temperature range covered by only about $0.2 \%$, which is well within the experimental error.

All values of $\epsilon^{\prime} 2$ reported up to now wore calculated on the basis of $\mathrm{C}_{0}=9.7 \mu \mu f$. (soo EXPERIMENTAL, Dielectrio cell). Actually, this was valid only for paper sample \#I, while for samples \#2 and \#3 the true value was $9.0 \mu \mu f$. Correction for this change in $C_{0}$ involves a simplo addition of 0.010 to the reported values of $\epsilon_{2}^{\prime}$, while $\epsilon^{\prime \prime} 2$ is not affected at all. All tabulated values as well as all subsequent graphical values of $\epsilon_{2}^{\prime}$ are corrected for in this way. Delevanti and Hansen (16) showed that the relationship between 


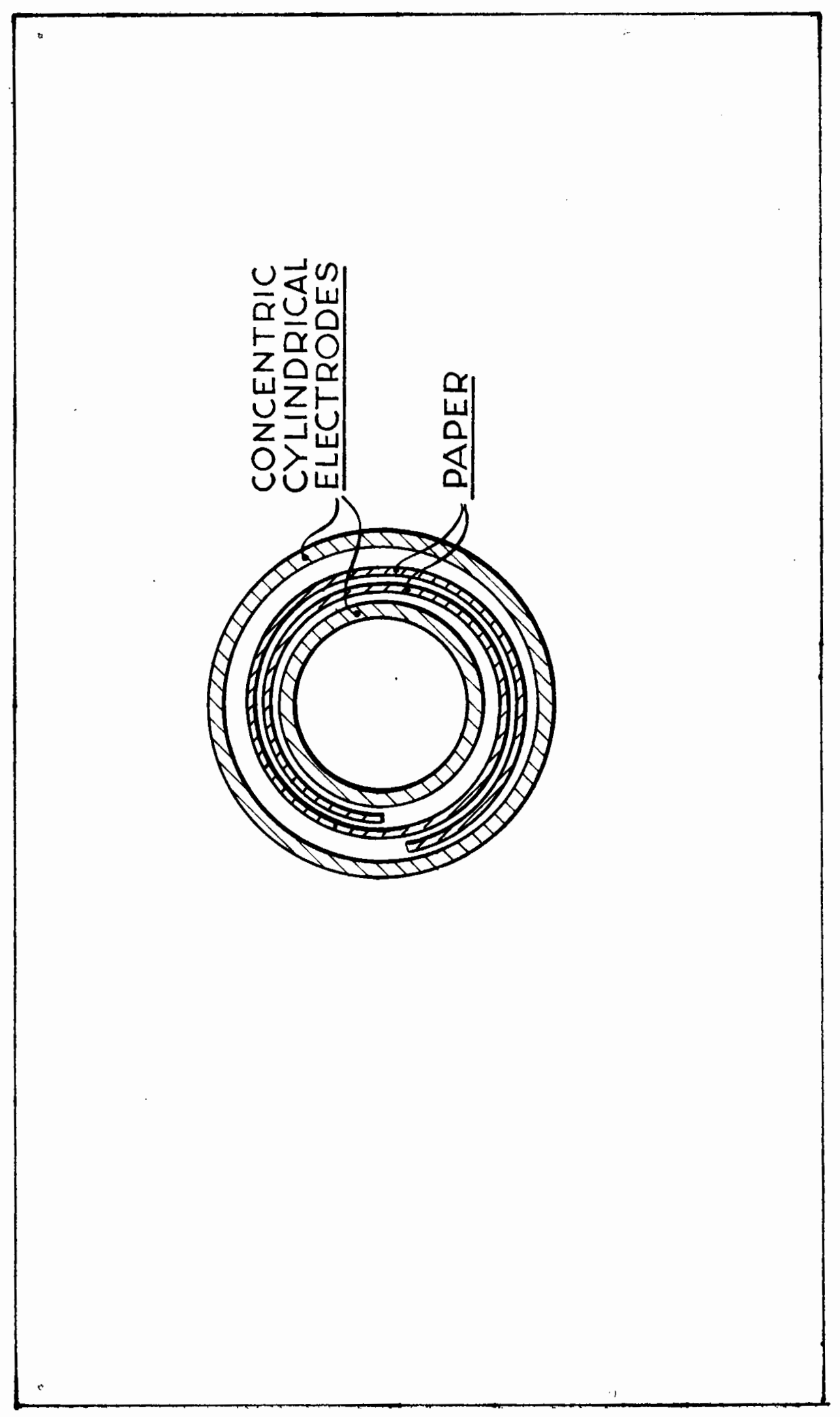




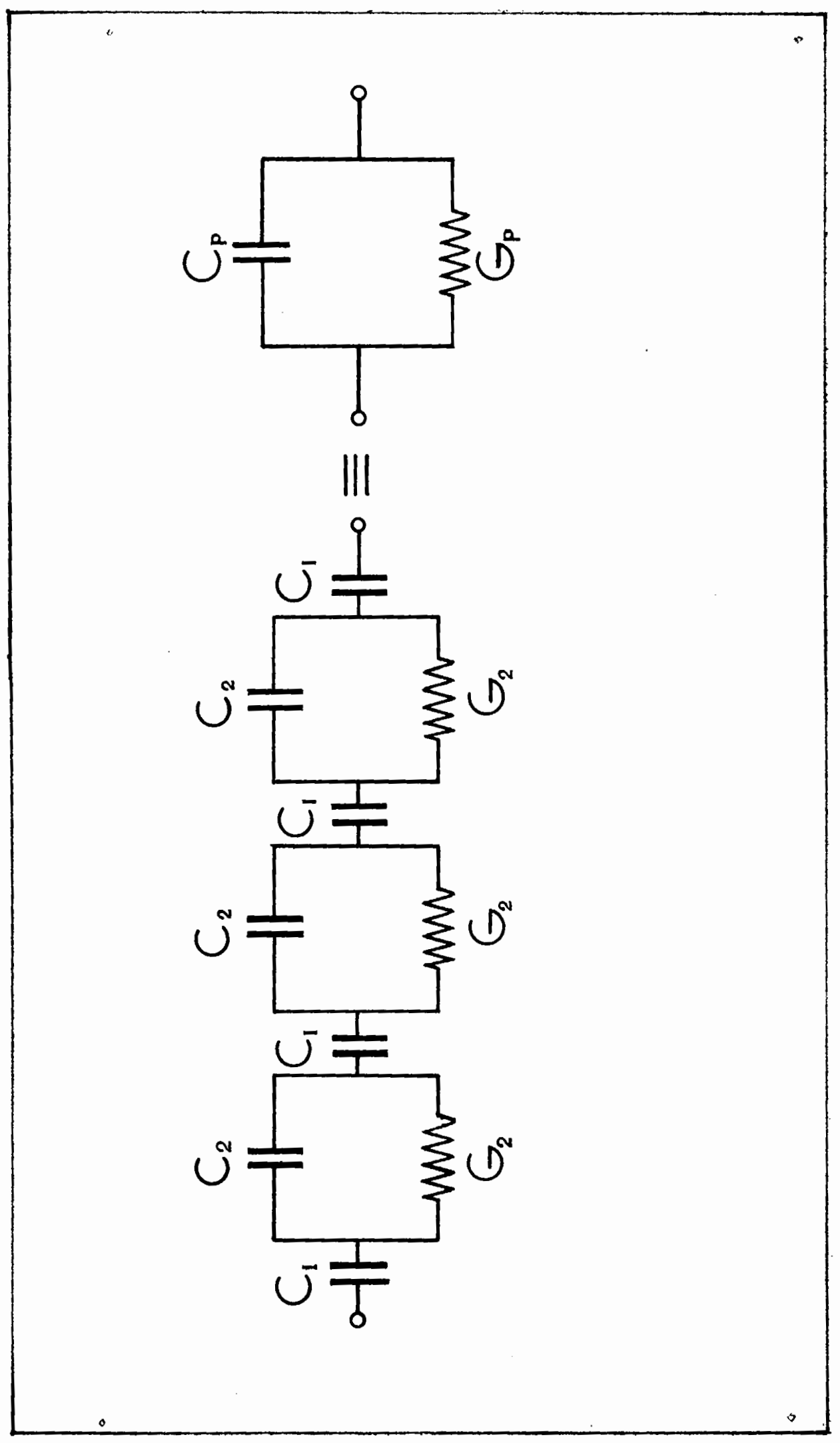


TABLE XXII

Dielectric dispersion at $1 \mathrm{MO}$. of paper containing 0.0 and $5.3 \%$ adsorbed water

\begin{tabular}{lcccc|ccccc}
\hline \multicolumn{7}{c}{$0.0 \%$ Water } & \multicolumn{5}{c}{$5.3 \%$ Water } \\
\hline Tomp. & $\epsilon_{2}^{\prime}$ & $\epsilon_{1}^{\prime}$ & $\epsilon_{2}^{\prime \prime}$ & $\epsilon_{1}^{\prime \prime}$ & $T_{\text {emp. }}$ & $\epsilon_{2}^{\prime}$ & $\epsilon_{1}^{\prime}$ & $\epsilon_{2}^{\prime \prime}$ & $\epsilon_{1}^{\prime \prime}$ \\
\hline 26.5 & 1.322 & 1.638 & .0154 & .0268 & 20.4 & 1.453 & 1.964 & .0234 & .0462 \\
14.6 & 1.310 & 1.610 & .0160 & .0276 & 10.2 & 1.444 & 1.939 & .0241 & .0471 \\
4.8 & 1.301 & 1.587 & .0160 & .0273 & -1.0 & 1.427 & 1.891 & .0250 & .0479 \\
-7.7 & 1.291 & 1.563 & .0152 & .0256 & -12.6 & 1.412 & 1.850 & .0260 & .0490 \\
-19.4 & 1.281 & 1.540 & .0140 & .0234 & -22.6 & 1.403 & 1.826 & .0262 & .0488 \\
-30.6 & 1.274 & 1.525 & .0124 & .0205 & -34.8 & 1.373 & 1.748 & .0258 & .0465 \\
-42.9 & 1.264 & 1.502 & .0105 & .0172 & -46.4 & 1.349 & 1.688 & .0243 & .0427 \\
-56.5 & 1.257 & 1.486 & .0084 & .0137 & -55.2 & 1.332 & 1.646 & .0225 & .0388 \\
\hline
\end{tabular}


$-85-$

FIGURE 16

Effect of the transformation of $\epsilon^{\prime \prime} 2$ to $\epsilon^{\prime \prime} I$ on dielootrio dispersion at I Mc. of paper containing 0.0 and $5.3 \%$ adsorbed water. 


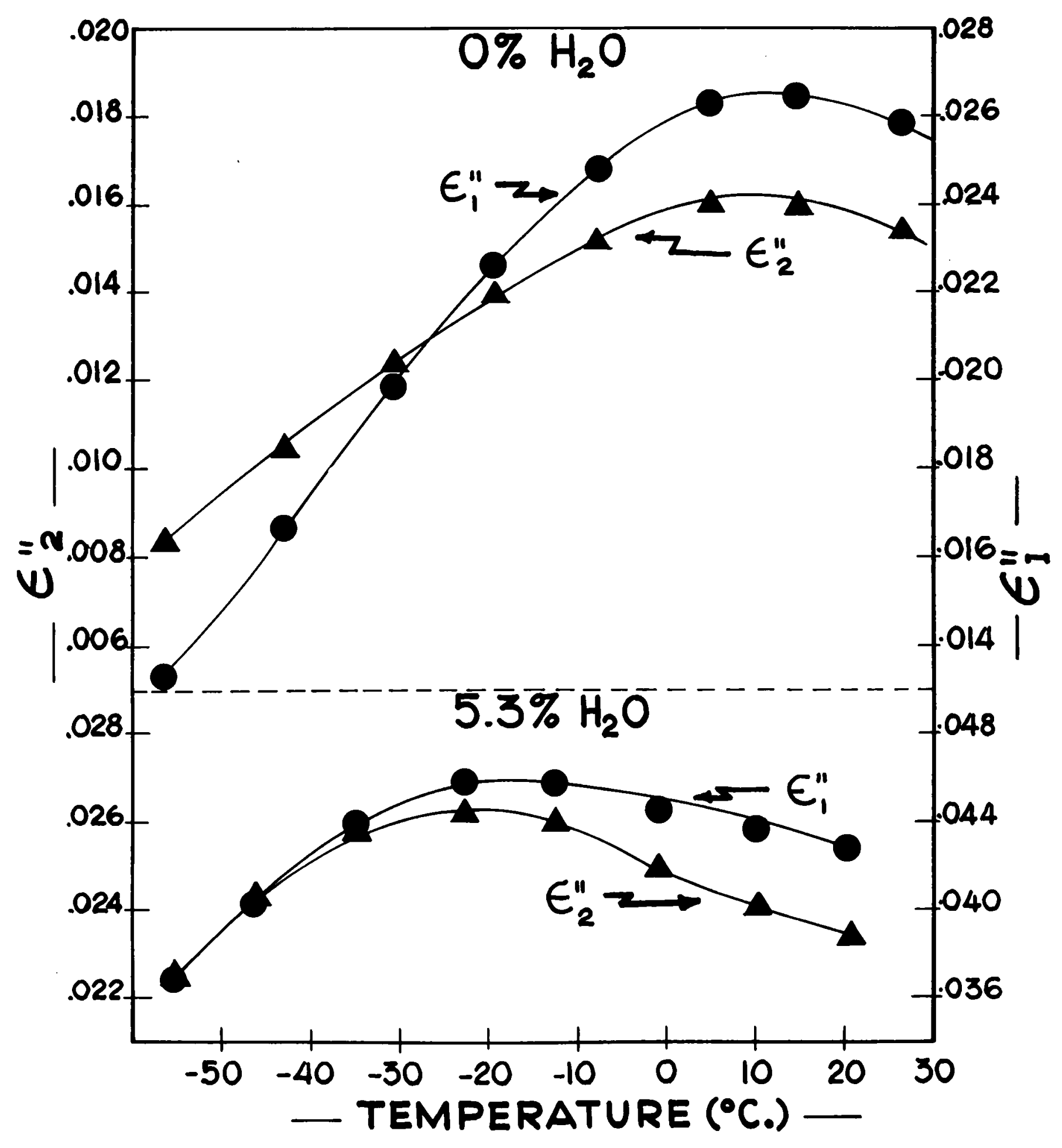


the density and dielectric constant of paper is expressed by a clausiusMosotti type of equation:

$$
\frac{1}{d} \frac{t^{\prime}-1}{t^{\prime}+2}=\mathrm{K}
$$

whore $d$ is the density and $K$ is a constent for a particular fibro. These rosults were confirmod by Calkins with an improved apparatus (8).

Thus, by means of equations (1) and (4) it is possible to calculate absolute values of the dieleotrio constant for collulose from values obtained for the compound dieleotric paper-vapor. In Tablo $\overline{\mathrm{XXIII}}$ is presented for dry cellulose at $25^{\circ} \mathrm{C}$. a comparison of the results of Brown (7), Calkins (8), and the present author. Brom measurod $\epsilon_{2}$ for an experimental arrangement similar to the one used in this work. His value for $V_{2} / v$ was 0.648 . From this and using equation $(1), \epsilon_{1}^{\prime}$ was oalculated, this corresponding to the measured sample density of 0.610. Using equation (4) $\epsilon^{\prime}$ was obtained for the cellulose fibre, assuming a density of 1.55 (33). Also, $\epsilon_{2}^{\prime}$ was calculated for $V_{2} / V=0.625$ and a semple density of 0.496 , corresponding to the arrangement in this work. Calkins measured $\epsilon_{1}^{\prime}$ directly; $\epsilon_{2}^{\prime}$ and $\epsilon^{\prime}$ were obtained as desoribed above, $t_{2}^{2}$ corrosponding to the arrangement in this work. If it is assumed that the fibres in the samples examined were in a plane perpendioular to the olectrical field then the differences in the results of the various workers may be accounted for at least partially on the basis of the dielectric anisotropy of cellulose. The transverse and axial dielectric constants of the cellulose crystallite hare been 
TABLE XXIII

Dielectric constant of dry cellulose at $25^{\circ} \mathrm{C}$.

\begin{tabular}{|c|c|c|c|c|c|c|}
\hline Data & Material & Freq; & Reported & Values & Reoalculated & Values \\
\hline & & & Donsity & Diel. Const. & \multirow{2}{*}{$\begin{array}{l}\epsilon^{\prime} 2 \\
\text { Density }=.496 \\
V_{2} / v=.625\end{array}$} & \multirow[t]{2}{*}{$\epsilon^{\prime}$} \\
\hline & & & $\left(V_{2} / v=.648\right)$ & & & \\
\hline Brown & linen paper & 300 & .610 & $\epsilon_{2}^{\prime}=1.363$ & 1.282 & 3.76 \\
\hline Calkins & cotton paper & 1 & .8 & $\epsilon_{1}^{\prime}=2.42$ & 1.364 & 5.94 \\
\hline Present & $\begin{array}{l}\text { paper of } \\
75 \% \text { Iinen } \\
+25 \% \text { cotton }\end{array}$ & $\begin{array}{r}300 \\
10 \\
1\end{array}$ & $\begin{array}{c}\left(\frac{V_{2}}{V}=.625\right) \\
.496\end{array}$ & $\begin{array}{r}\epsilon_{2}^{\prime}=1.334^{\mathrm{K}} \\
\quad 1.351 \\
1.357^{\mathrm{k}}\end{array}$ & $\begin{array}{l}1.334 \\
1.351 \\
1.357\end{array}$ & $\begin{array}{l}4.96 \\
5.48 \\
5.67\end{array}$ \\
\hline
\end{tabular}

t Estimatod from the results at other froquencies 
found to be 5.27 and 7.19 , respectively, at a frequency of $300 \mathrm{Kc} .(7)$. In cotton the fibrils are arranged spirally about the fibre axis whereas in linen they are nearly parallel to the fibre axis. Thus, when dielootric constants are moasured transverse to the fibre axis, the values should increase in the order linen, linen + cotton, and cotton: the rom sults given in Table XXIII fall into this order.

Using the same method, it is possible to obtain the dielectric constant of cellulose as function of vapor content. Calculations were made from data at $1 \mathrm{MC}$. and $20^{\circ} \mathrm{C}$, and the results aro show in Table XXIV. The rariation of fibre density with water content was obtained from Hermans (33). It was assumed that mothanol and othanol had no offect on fibre density. If the data on water are any oriterion, there being little change orer the range studiod, this assumption appears quite $\operatorname{logicxl}$

The values of $G$ are plottod versus rapor content in Figure 17 . The rate of increase of $\epsilon^{\prime}$ incroases in the order ethanol, mothanol, and water, the changes in tho case of othanol being very small. E.g., at 5.3\% rapor content, ethanol has produced a percentage change in $\epsilon^{8}$ of only 18, while the corresponding change in the case of water is as high as $100 \%$. The values of $\epsilon^{\prime}$ for dry paper in the curves for water, and for methanol and othanol correspond to the values for paper samples \#2 and \#3. The percentage differenoe is only 2, which is a good check on the reproducibility of the results. 
$-89-$

FIGURE 17

Dieleotric constant of collulose at 1 Mc. and $20^{\circ} \mathrm{C} .8$ its rariation with amount of rapor adsorbod. 


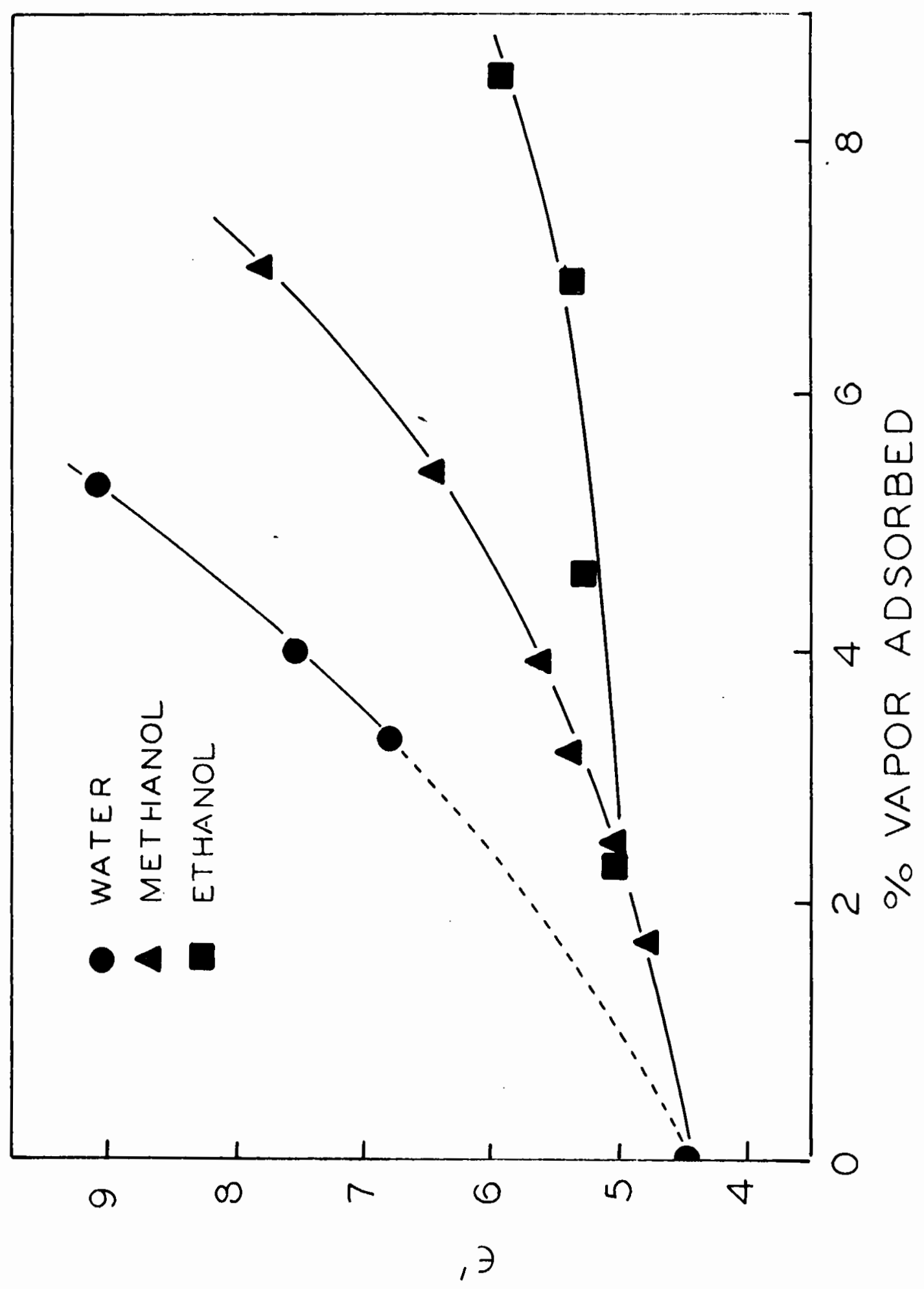




\section{TABLE XXIV}

Dieloctric constant of cellulose at $1 \mathrm{MC}$. and $20^{\circ} \mathrm{C} .8$ its variation with amount of vapor adsorbed

\begin{tabular}{lllllll}
\hline \% wator & $v_{2 / N}$ & $\begin{array}{c}\text { samplo } \\
\text { density }\end{array}$ & $\begin{array}{c}\text { fibro } \\
\text { donsity }\end{array}$ & $\epsilon^{\prime} 2$ & $\epsilon_{1}^{\prime}$ & $\epsilon^{\prime}$ \\
\hline 0.0 & .625 & .496 & 1.55 & 1.315 & 1.621 & 4.46 \\
3.3 & .630 & .509 & 1.56 & 1.397 & 1.822 & 6.80 \\
4.0 & .632 & .510 & 1.55 & 1.418 & 1.874 & 7.54 \\
5.3 & .635 & .514 & 1.54 & 2.453 & 1.965 & 9.08 \\
\hline
\end{tabular}

\% Methanol

\begin{tabular}{lllllll}
\hline 1.7 & .638 & .503 & 1.55 & 1.341 & 1.663 & 4.78 \\
2.5 & .640 & .505 & & 1.354 & 1.690 & 5.04 \\
3.2 & .640 & .508 & & 1.368 & 1.725 & 5.39 \\
3.9 & .643 & .510 & & 1.380 & 1.749 & 5.64 \\
5.4 & .646 & .515 & & 1.410 & 1.819 & 6.46 \\
7.0 & .648 & .521 & & 1.448 & 1.914 & 7.83 \\
\hline
\end{tabular}

\% Ethanol

\begin{tabular}{lllllll}
\hline 2.3 & .640 & .504 & 1.55 & 1.353 & 1.688 & 5.04 \\
4.6 & .646 & .511 & & 1.371 & 1.721 & 5.28 \\
6.9 & .648 & .520 & & 1.382 & 1.744 & 5.36 \\
8.5 & .651 & .526 & & 1.408 & 1.802 & 5.93 \\
\hline
\end{tabular}


Application of the Theory of Absolute Reaction Rates

In all cases in this work the linearity of the plot of $\log T$ versus $1 / T$ permitted analysis of the data in terms of the theory of absolute reaction rates $(25,28)$. As shown in the Introduction a freo energy of activation for relaxation is defined:

$$
\frac{1}{\tau}=\frac{\mathrm{kT}}{\mathrm{h}} e^{-\Delta \mathrm{F} / \mathrm{RT}}
$$

or, breaking up the free onergy term into the entropy and enthalpy of actiration,

$$
\frac{1}{T}=\frac{\mathrm{kT}}{\mathrm{h}} e^{-\Delta \mathrm{H}^{\mathrm{t}} / \mathrm{RT}} e^{\Delta s^{t} / \mathrm{R}}
$$

$\mathrm{k}$ and $\mathrm{h}$ are the Boltzmann and Planck constants, respectively, and $\mathrm{T}$ is the absolute temperature. All values of $\Delta F^{t}, \Delta H^{\hbar}$, and $\Delta S^{t}$ reported here are for the temperature $298^{\circ} \mathrm{K}$. and were calculated as follows:

$$
\begin{aligned}
\Delta F^{\star} & =1364[12.793+\log T] \\
\Delta H^{\star} & =4.576 \sigma-592 \\
\Delta s^{\star} & =\frac{1}{298}\left[\Delta H^{\star}-\Delta F^{\star}\right] \\
\sigma & =\frac{\Delta(\log T)}{\Delta(1 / T)}
\end{aligned}
$$

The plots of $\log T$ versus $1 / T$ for paper containing adsorbed water, methanol, and othanol, respectively, are presented in Figures 18, 19 and 20. From these plots $T$ was detormined in each case at $298^{\circ} \mathrm{K}$. 
Log $T$ versus $1 / \mathrm{T}$ for paper oontaining $0.0,3.3$, and $5.3 \%$ adsorbed water.

\section{FIGURE 19}

$\log T$ versus $1 / T$ for paper containing $0.0,1.7,2.5,3.2,3.9$, 5.4 , and $7.0 \%$ adsorbed metharol.

\section{FIGURE 20}

Log $T$ rersus $1 / T$ for paper containing $0.0,2.3,4.6,6.9$, and 8.5\% adsorbed othanol. 


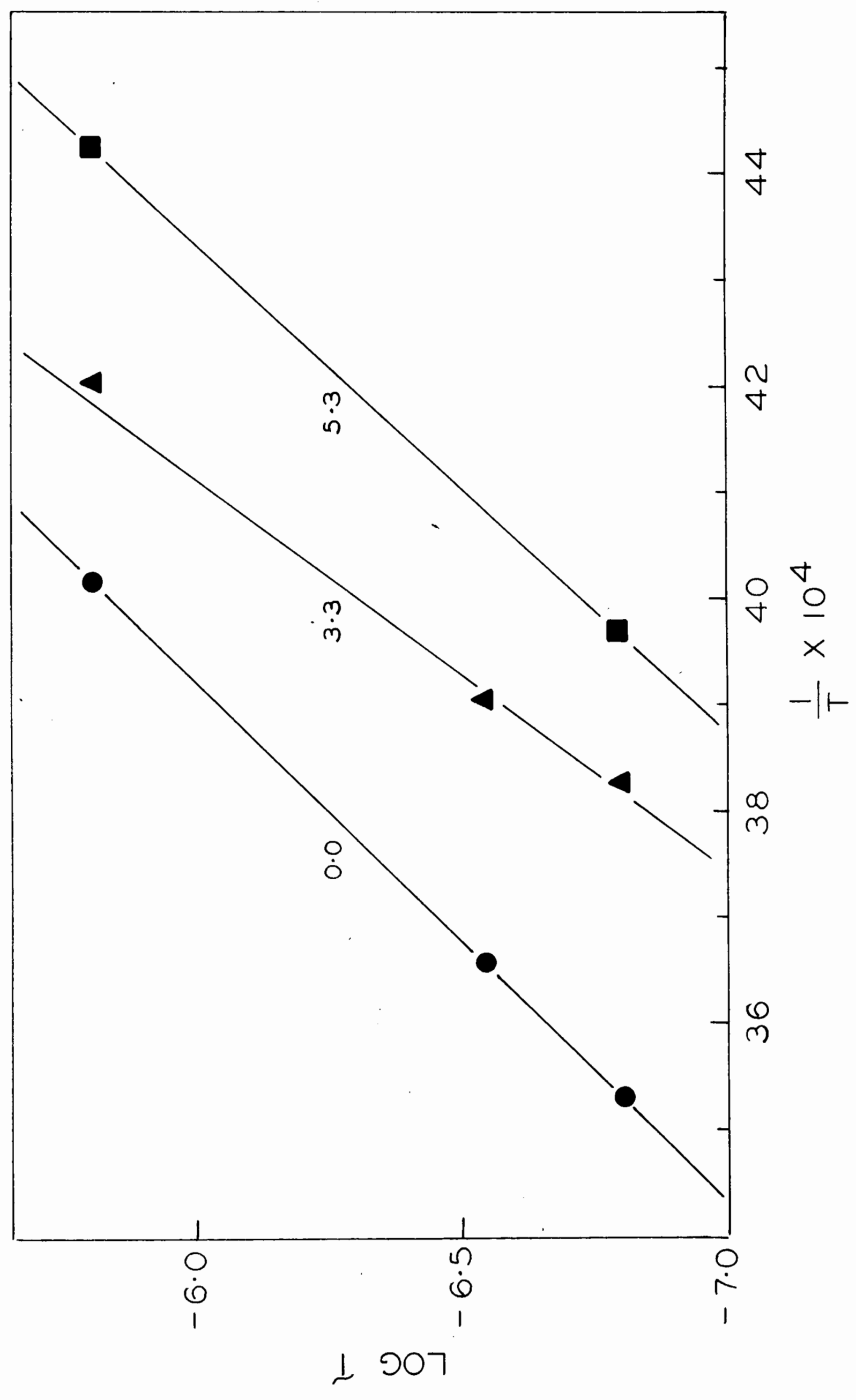




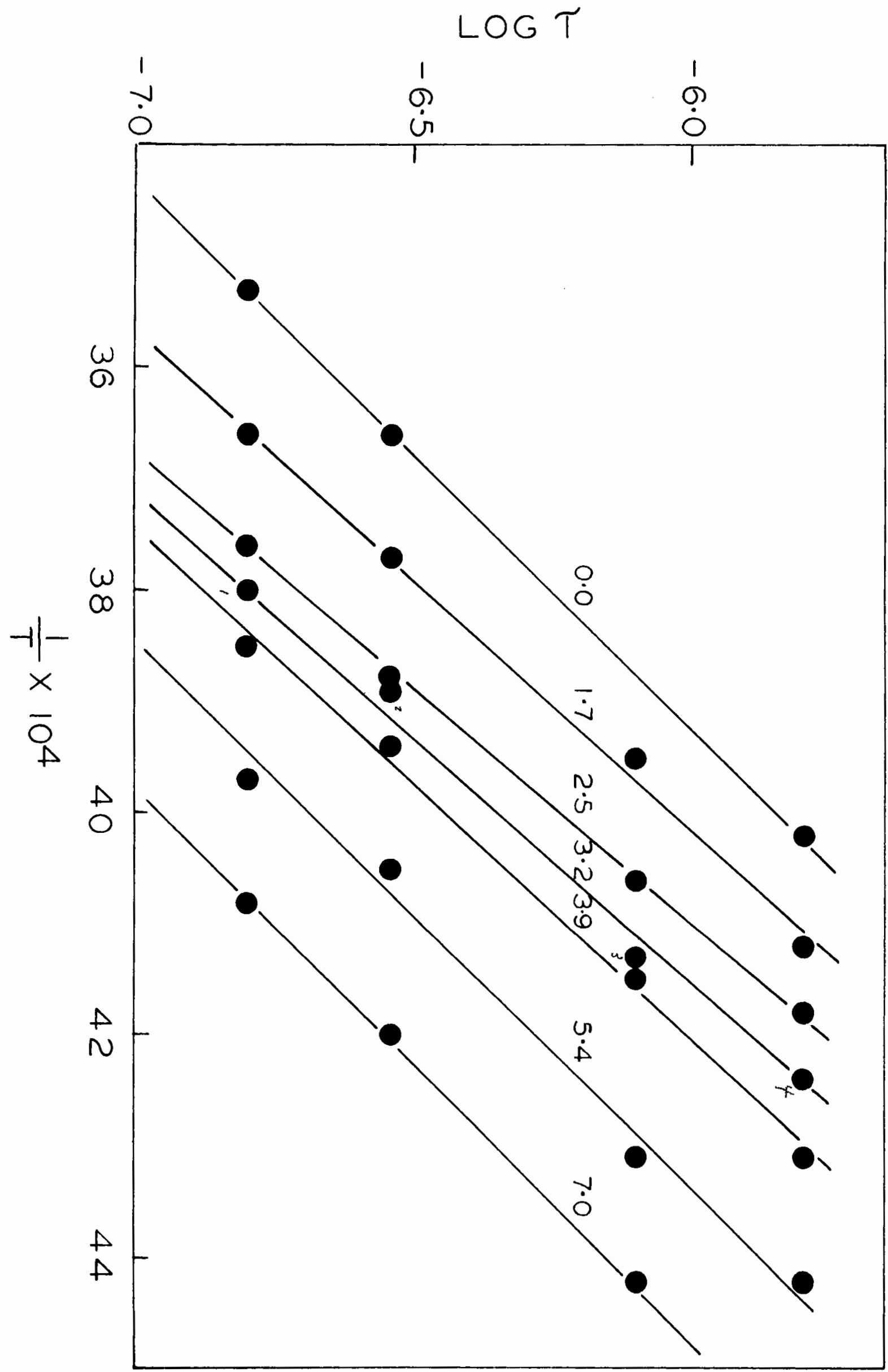




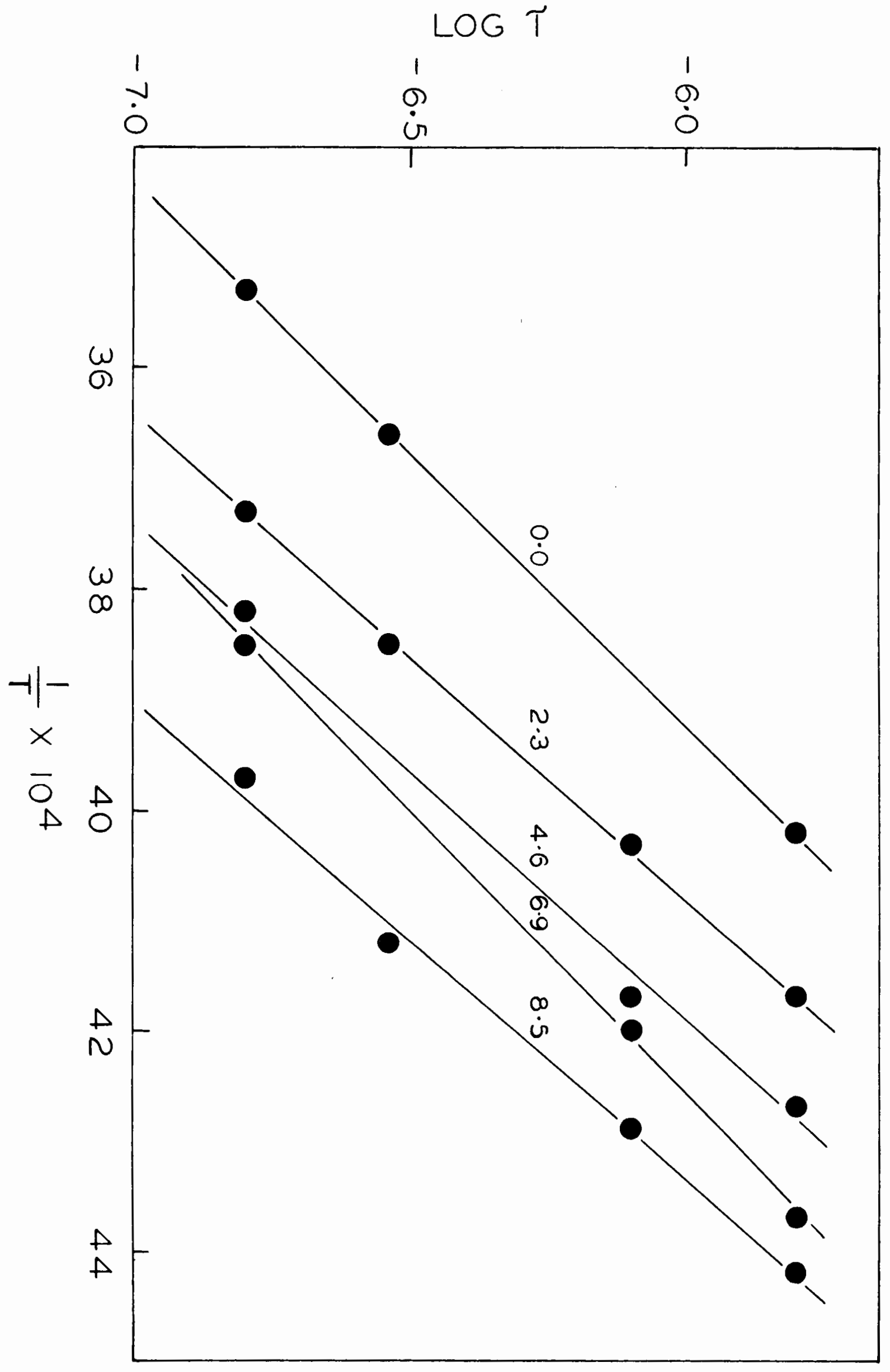


These values of $T$ as well as of $\sigma, \Delta F^{t}, \Delta H^{t}$, and $\Delta S^{t}$ are presented in Table $\overline{\overline{X V}}$.

Let us first consider the data for methenol. The variation of each of $\Delta F^{\star}, \Delta H^{\star}$, and $\Delta S^{\star}$ with $\%$ adsorbod methanol is shown in Figure 21. Following directly from the trends in $T, \Delta t$ is seen to decrease quite rapidly at first, levels off in the range 3 to $4 \%$ and then proceeds to decrease further although not nearly so rapidly as previously. On the other hand, both $\Delta H^{t}$ and $\Delta S^{\text {t }}$ go through a pronounced maximum at $2.7 \%$.

A glance at Table $\overline{X X V}$ indicates that the data for water in all probability shows similar tronds, $\Delta H^{\star}$ and $\Delta S^{\mathbf{t}}$ passing through maxima quite close to $2.7 \%$. These trends are observed as well for ethenol, as indicated in Figure 22.

At $2.7 \%$ then the restriction to dipole rotation is at a maximum in all threo cases. It is interesting that at this same point (for water) the donsity as well as both refractive indices of native fibres likewise have a maximum value (33). One might expect the same to be the case for methanol and ethanol. Porhaps the decrease in height of the $\Delta H^{t}$ and $\Delta S^{t}$ curves as one procedes from water to methanol reflects a corresponding decrease of the density effect in the throe cases.

The picture, howerer, is not complete. It is necossary to reconcile the absence of a maximum in the $\Delta F^{\text {t }}$ ourve together with its presence in the corresponding curves for $\Delta S^{t}$ and $\Delta H^{t}$. Similar nonparallelism in the trends of the three quantities has been frequently observed in chemioal reactions in solution and is characteristic of phase changes (56). Large parallel changes in both $\Delta H^{t}$ and $\Delta S^{t}$ for the most 
TABLE XXV

Evaluation of Froe Enorgy, Rnthalpy \& Entropy of

Aotivation for Rolaxation for Paper at $298^{\circ} \mathrm{K}$.

\begin{tabular}{|c|c|c|c|c|c|}
\hline $\begin{array}{l}\text { \% Adsorbod Wator } \\
\text { (gms./gm. dry papor) }\end{array}$ & $\begin{array}{c}T \times 10^{9} \\
(\text { socs.) }\end{array}$ & $\sigma$ & $\underset{(\mathrm{kcals} . / \text { mole })}{\Delta \mathrm{H}^{\mathrm{t}}}$ & $\underset{\text { (koals./molo) }}{\Delta F^{\star}}$ & $\begin{array}{l}\Delta s^{t} \\
\left(0 . u_{0}\right)\end{array}$ \\
\hline 0.0 & 69.2 & 2060 & 8.84 & 7.68 & 3.9 \\
\hline 3.3 & 8.2 & 2700 & 11.76 & 6.42 & $17 \cdot 9$ \\
\hline 5.3 & 7.0 & 2200 & 9.48 & 6.33 & 10.6 \\
\hline
\end{tabular}

\% Adsorbed Mothanol

\begin{tabular}{crrrrr}
\hline 0.0 & 69.2 & 2060 & 8.84 & 7.68 & 3.9 \\
1.7 & 35.5 & 2210 & 9.50 & 7.28 & 7.5 \\
2.5 & 17.4 & 2380 & 10.30 & 6.86 & 11.5 \\
3.2 & 14.4 & 2320 & 10.00 & 6.75 & 11.0 \\
3.9 & 15.0 & 2160 & 9.27 & 6.77 & 8.4 \\
5.4 & 9.9 & 2040 & 8.76 & 6.53 & 7.5 \\
7.0 & 5.4 & 2040 & 8.72 & 6.17 & 8.6 \\
\% Adserbod Ethanol & & & & & \\
\hline 0.0 & 69.2 & 2060 & 8.84 & 7.68 & 3.9 \\
2.3 & 20.4 & 2350 & 10.16 & 6.95 & 10.8 \\
4.6 & 14.6 & 2220 & 9.57 & 6.76 & 9.4 \\
6.9 & 15.1 & 2020 & 8.65 & 6.78 & 6.3 \\
8.5 & 5.5 & 2320 & 10.02 & 6.18 & 12.9 \\
\hline
\end{tabular}




\section{FIGURE 21}

Variation with $\%$ adsorbed methanol of $\Delta H^{t}, \Delta F^{t}$, and $\Delta S^{t}$ for di-lectric relaxation for paper at $298^{\circ} \mathrm{K}$.

\section{FIGURE 22}

Variation with \% adsorbod othanol of $\Delta H^{t}, \Delta F^{t}$, and $\Delta S^{t}$ for dielectric relaxation for paper at $298^{\circ} \mathrm{K}$. 


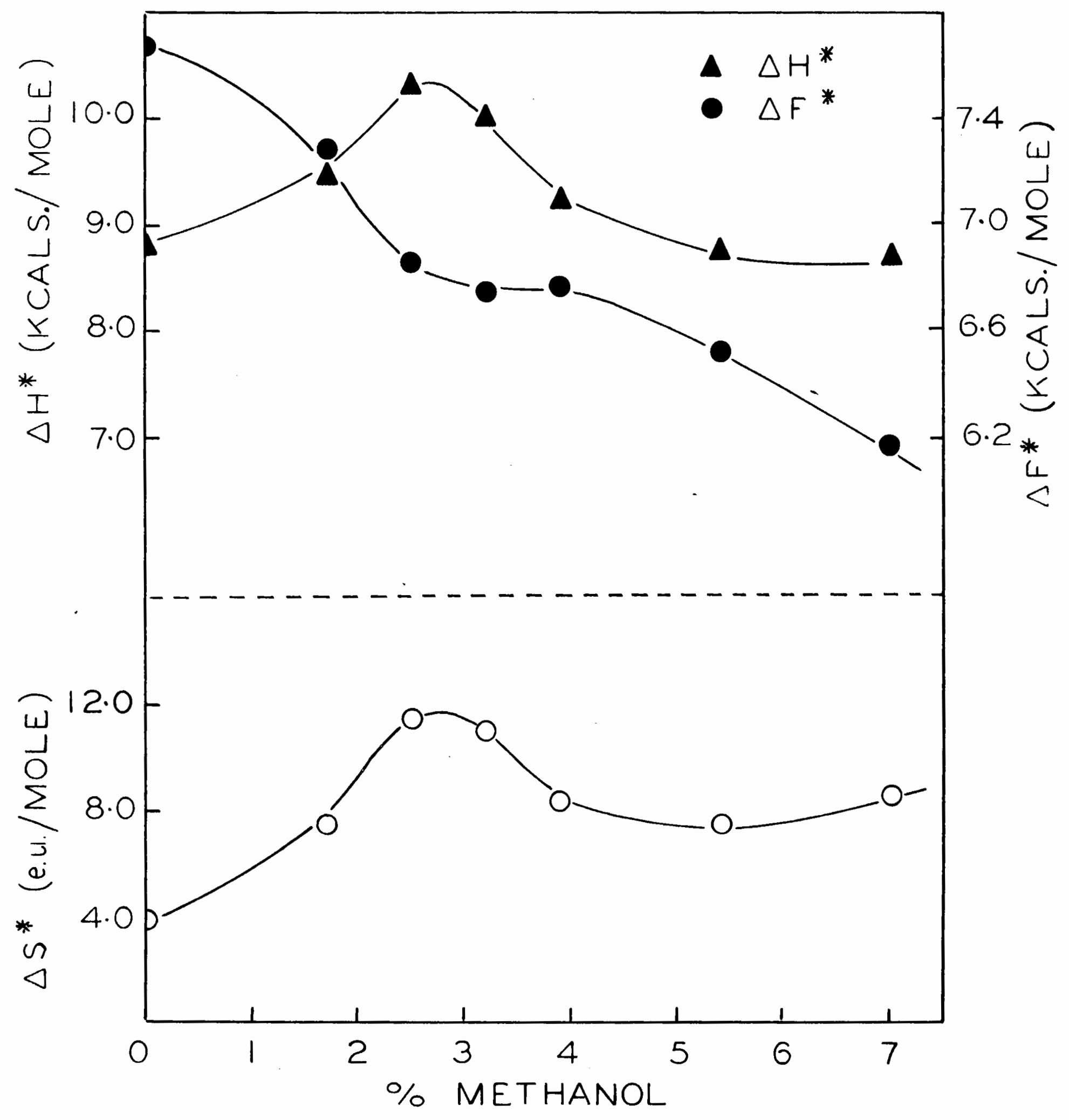




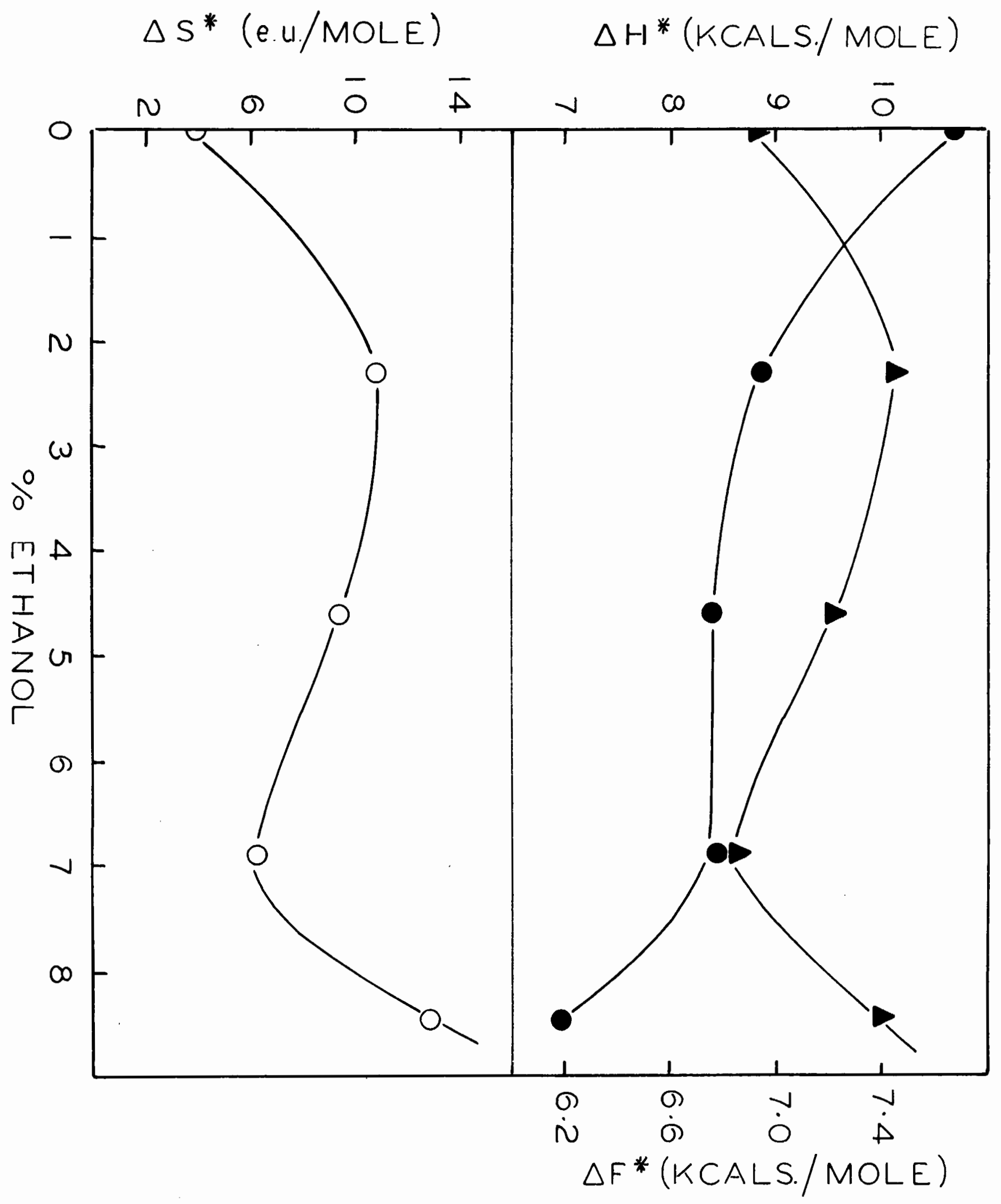


part compensate each other so that $\Delta r$, and consequently the reaction rate, remains very noarly the same.

The dielectric relaxation process investigated here may then logically be considered to occur as follows, still referring to Figure 21. At the maximum point in the $\Delta S^{\text {t }}$ curre a maximum number of bonds must be broken per oriontation of a single dipole. The enthalpy necessary is also at a maximum, but it is possible at the same time that the amount per bond broken may be less than for lower vapor contents. This is to be expected, in fact, on the assumption that the rotating dipoles are hydroxyl groups and that the hydroxyl groups of the sorbed vapor are also rotating. For it is woll known that heats of wotting of cellulose become progressively smeller with increase in moisture content (64). One may then argue that the relexation time is a function of the enthalpy increase per bond broken per rotation as woll as of the number of bonds broken, or in other words, a function of the free energy increase. At vapor contents higher than that corresponding to the maximum point, the overall density of the cellulose system decreases and the number of broken bonds per dipole orientation, in other words, $\Delta s^{t}$, suffers a corresponding decrease. At the same timo, the enthalpy increase per bond broken becomes even smaller so that there is a corresponding decrease in relaxation time.

In the above sense then water as woll as methanol and othanol may be considered as having in cellulose a plasticizing action similar to that observed in other polymer systems (11, 22, 23, 52). The distinctness of the vapor content of $2.7 \%$ is manifested 
Variation of $T_{m}$ with \% adsorbod methanol at the insoribed frequencies. 


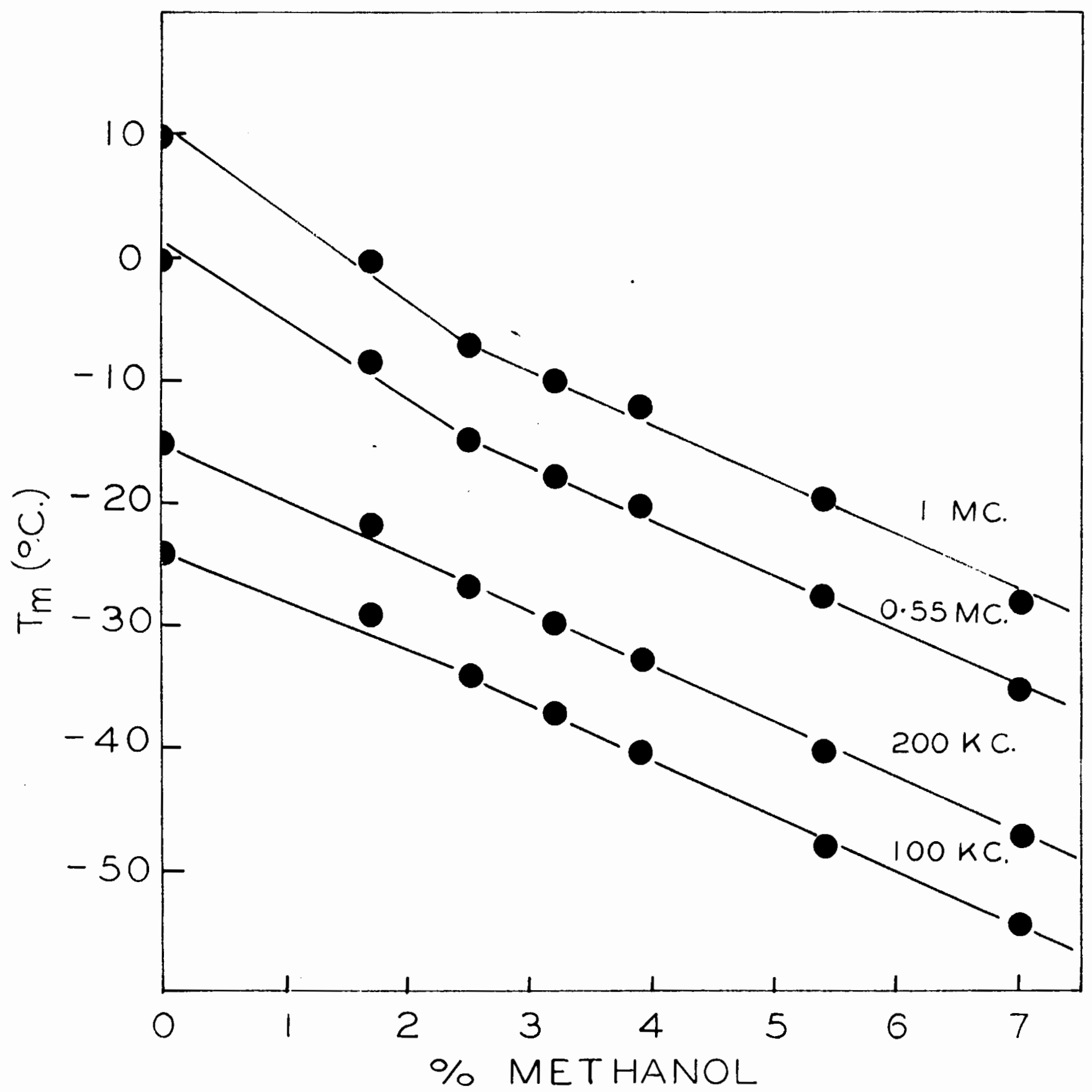


in yot another fashion. When $\mathrm{T}_{\mathrm{m}}$ is plotted rersus \% mothanol for each of the four experimental frequencies, one obtains the plots of Figure 23. These plots are linear with a discontinuity at $2.5 \%$ Above this point the slope is the same for all the frequencies, the deviation from the arerage boing less than 1\%. Bolow $2.5 \%$ on the other hand the slope undergoos a marked increase with decrease in froquency. In order to onsure better illustration of the relationships the points were taken from the $\log T$ vorsus $1 / T$ lines of Figure 19 rathor than directly from tho exporimental data.

The plots are deseribed by the following oquations, $T_{m}$ being expressed in degrees absolute:

$$
\begin{array}{ll}
\mathrm{T}_{\mathrm{m}} & =\mathrm{K}_{1}(\% \mathrm{MOH})+\mathrm{K}_{2} ; \% \mathrm{MOOH}<2.5 \\
\mathrm{~T}_{\mathrm{m}} & =-4.54(\% \mathrm{MOH})+\mathrm{K}_{3} ; \quad \% \mathrm{MOH}>2.5
\end{array}
$$

In Table $\overline{X X V I}$ are presented the values of $K_{1}, K_{2}$, and $K_{3}$ for the difforent frequencies.

Effect of Vapor Content on Increase in Loss Maximum

For the case of a single rolexation time $T$, the maximum value of $\epsilon^{\prime \prime}$ is given by $(48)$ :

$$
\epsilon^{\prime \prime} \max =\frac{2 \pi}{27 k T}\left(\epsilon_{0}+2\right)^{2} \mu^{2} n
$$

where $\mathrm{k}$ is the Boltzmann constant $=1.38 \times 10^{-16}$ erg/degreo, $\mathrm{T}$ is the absolute tomperature, $\epsilon_{\theta}$ is the static dieloctrio constant, and $n$ is the 
$-99-$

TABLE XXVI

Evaluation of constants for the plots of Figure 23

\begin{tabular}{cccc}
$\begin{array}{c}\text { Frequomoy } \\
\text { (kcs.) }\end{array}$ & $K_{1}$ & $K_{2}$ & $K_{3}$ \\
\hline & & & \\
100 & -4.06 & 249.0 & 250.2 \\
200 & -4.54 & 258.0 & 258.0 \\
550 & -6.09 & 273.7 & 269.7 \\
1000 & -7.26 & 284.6 & 277.3 \\
& & & \\
\hline
\end{tabular}


number of dipoles per cc. $\mu$ is the dipole moment, assumed to be $1.7 x$ $10^{-18}$ e.s.u. for the hydroxyl group $(48) . \mathrm{d} \epsilon^{\prime \prime}{ }_{\max } /$ dn is given by:

$$
\frac{d \epsilon^{\prime \prime} \max }{d n}=\frac{2 \pi}{27 k T}\left(\epsilon_{0}+2\right)^{2} \mu^{2}
$$

assuming no change in $\mathrm{T}$ or $\epsilon_{0^{\circ}}$. In this way a loss ralue is assigned to a single adsorbod dipole in one cc. of material. In order to be consistent with the convention of expressing the amount of adsorbed vapor in terms of grams per 100 grams of dry material, a loss value is assigned to one gram of adsorbed dipole per 100 grams dry material as follows:

$$
\frac{d \epsilon^{\prime} \cdot \max }{d n_{c}}=\frac{2 \pi}{27 k T}\left(\epsilon_{0}+2\right)^{2} \mu^{2} \frac{N d}{100 \pi}
$$

where $N$ is Avogradro's number, $M$ is the woight of $N$ dipoles, and $d$ is the donsity of the matorial.

$d t^{\prime \prime m a x} / d n_{0}$ may be obteined experimentally as woll, as indicatod in the Rosults. However, as omphasized before, the linear plots of Figure 14 describe the compound dioloctric collulose-rapor - rapor, wheroas data for collulose itsolf are desired for purposes of comparison. This is obtained as follows: the requisito $E^{\prime \prime} 2$ data was transformod to $t$ ' 1 by the mothod desoribod in Analysis of Dioloctric. It has boen shom that the dissipation factor of a paper sheet is roughly diroctly proportional to its density $(8,16)$. With this relation $\epsilon^{\prime \prime}{ }_{1}$ was transformod to $\epsilon^{\prime \prime}$ for the cellulose fibre itself, using the density

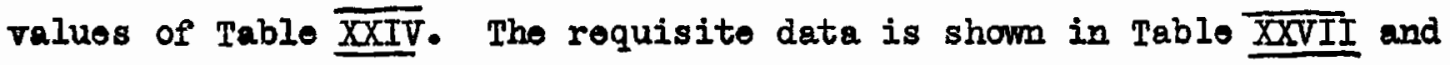


- 101 .

FIGURE 24

C' $\max$ for the cellulose fibro: its variation with rapor content. 


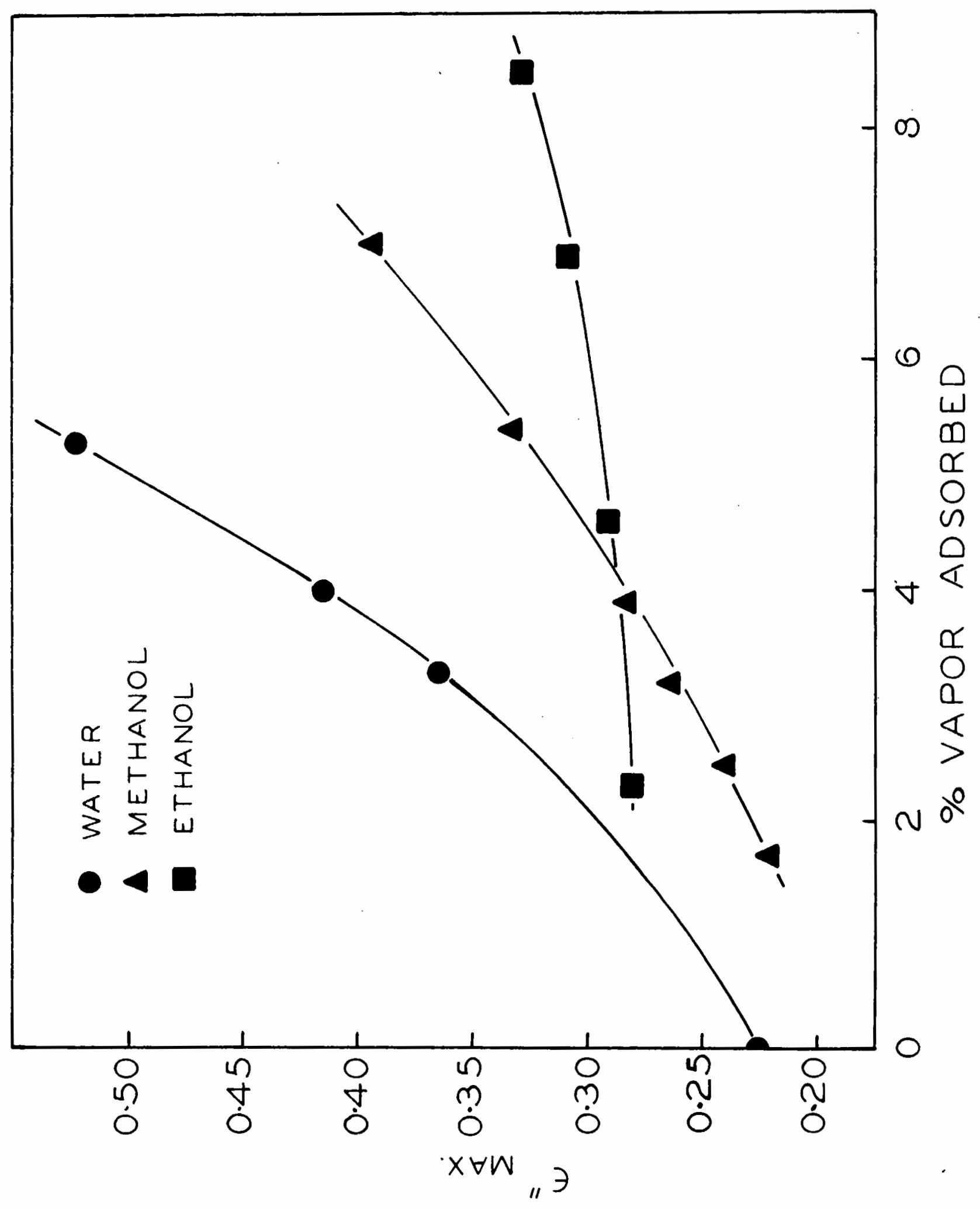


plotted in Figure 24. The plots are slightly curred, the currature being groatest in the oase of water. This is no doubt a consequence of the fact that $T$ decreases and $\epsilon_{0}$ incroases with increase in vapor content, the combined effect being greatest for wator, presumably. From the slopes of these ourves (at $5.3 \%$ repor content ) values of $\mathrm{d} \epsilon^{\prime \prime}{ }_{\max } / \mathrm{dn} \mathrm{c}_{\mathrm{c}}$ wore computed; these are presented in Table $\overline{\text { XXVIII }}$ together with those obtained from the above equation, as well as the corresponding values for crystalline and amorphous terylene. It ought to be pointed out hore that by crystalline terylone is meant the normally occurring substance, which has a exystalline fraction of about $0.4(48)$. $\epsilon_{0}$ for dry cellulose was taken as 6 .

It will be noticed that in all cases in this tablo the exporimental value of $d \in \prime^{\prime m a d} / d n_{c}$ is much smaller than the theoretical. This can undoubtedly be explained on the basis of a sproad of relaxation times as a consequence of which the measured $\epsilon^{\prime} \max$ is considerably lowor than the theoretical value (38). Even so, the roported experimental values for cellulose are probably a little high as a result of the slight magaifying offect of a decrease in temperature on $\epsilon^{\prime}{ }_{\max }$. Hore oneassumes of course the correctness of the model used in calculating $\epsilon^{\prime \prime} \max$ " Theoretically, one would expect $d \epsilon^{\prime \prime}{ }_{\max } / \partial n_{c}$ to be considerably less for terylene-water than for collulese-water because of smaller values for $t_{0}$ and d. That this is so experimentally is evidence in favour of the assumption referred to above. The effeot of changes in $\epsilon_{0}$ and $d$ is manifested as woll in the smaller value of $d \epsilon^{\prime}{ }^{\prime m a x} / d n_{0}$ for crystalline torylene then for the amorphous modification. 
TABLE XXVII

$\epsilon " ' \max$ for the cellulose fibre: its variation with vepor content

\begin{tabular}{|c|c|c|c|c|c|c|c|}
\hline$\%$ Vapor & $\mathbb{T}_{m}$ & $\epsilon^{\prime \prime} 2 \max$ & $t_{2}^{\prime}$ & $t^{\prime} 1$ & $\epsilon^{\prime \prime} 1$ & $\epsilon^{\prime}$ & $\epsilon^{\prime}$ \\
\hline \multicolumn{8}{|l|}{ Wator } \\
\hline 0.0 & 10 & .0160 & 1.306 & 1.598 & .02740 & 4.24 & .227 \\
\hline 3.3 & -12 & .0218 & 1.353 & 1.707 & .03892 & 5.22 & .365 \\
\hline 4.0 & -17 & .0233 & 1.372 & 1.751 & .04225 & 5.66 & .415 \\
\hline 5.3 & -21 & .0262 & 1.404 & 1.828 & .04885 & 6.52 & .522 \\
\hline \multicolumn{8}{|c|}{ Nothanol } \\
\hline 1.7 & -8 & .0158 & 1.323 & 1.620 & .02680 & $4 \cdot 35$ & .222 \\
\hline 2.5 & -15 & .0171 & 1.328 & 1.629 & .02903 & 4.41 & .241 \\
\hline 3.2 & -16 & .0179 & 1.342 & 1.661 & .03082 & 4.68 & .265 \\
\hline 3.9 & -19 & .0190 & 1.350 & 1.675 & .03275 & $4 \cdot 79$ & .284 \\
\hline 5.4 & -26 & .0212 & 1.369 & 1.716 & .03701 & 5.14 & .334 \\
\hline 7.0 & -35 & .0232 & 1.394 & 1.773 & .04135 & 5.68 & .394 \\
\hline \multicolumn{8}{|l|}{ Ethomel } \\
\hline 2.3 & -5 & .0198 & 1.328 & 1.629 & .03362 & $4 \cdot 43$ & .281 \\
\hline $4 \cdot 6$ & -12 & .0210 & 1.338 & 1.643 & .03554 & $4 \cdot 46$ & .292 \\
\hline 6.9 & -13 & .0222 & 1.351 & 1.668 & .03784 & $4 \cdot 56$ & .309 \\
\hline 8.5 & -21 & .0231 & 1.366 & 1.700 & .03975 & $4 \cdot 78$ & .329 \\
\hline
\end{tabular}




\section{TABLE XXVIII}

$d E^{\prime \prime}{ }_{\max } / d n_{0}-T h o o r e t i c a l$ and experimental values for collulose and terylene

\begin{tabular}{|c|c|c|c|}
\hline Material & Theorotical & Exporimental & $\begin{array}{l}\text { Theoroti } \\
\text { Experimo }\end{array}$ \\
\hline $\begin{array}{l}\text { Terylono } \\
\text { (amorphous) }\end{array}$ & 0.245 & 0.0488 & 5.02 \\
\hline $\begin{array}{l}\text { Terylome } \\
\text { (erystallino) }\end{array}$ & 0.232 & .0433 & 5.35 \\
\hline $\begin{array}{c}\text { Cellulose } \\
+ \text { water }\end{array}$ & .676 & .0834 & 8.10 \\
\hline $\begin{array}{l}\text { Cellulose } \\
\text { t mothanol }\end{array}$ & .676 & .0638 & 10.6 \\
\hline $\begin{array}{l}\text { Cellulose } \\
+ \text { othenol }\end{array}$ & .676 & .0206 & 32.8 \\
\hline
\end{tabular}


SUMMARY AND CONCLUSIONS

Water is known to have a pronounced softening offect on cellu10s0. The dieloctric relaxation time (T) of a substance, together with rolated propertios, may be considered as a measure of the facility with which its dipoles can rotate in an alternating electric field. It would be expected then that in collulose $T$ would be affected to a groater or lesser extent by the presence of adsorbed water and similar vapors. It was found conveniont to perform experimonts with quantitative filter paper inserted in the measuring condenser in a wrap-around fashion. The necessity thus arose for dotermining whether or not relaxation times for this arrangement corrosponded to those for the paper itself. Electrical analysis showed that there was no doviation within oxperimental error. Using the equations obtained calculations wore made of the dielectric constant and maximum dielectric loss factor of the cellulose fibre as a function of per cent adsorbed water, methanol, and othanol, respectively, this being the order of decreasing effect. The value of the dielectric constant for dry cellulose was in agreoment with that obtained by previous workers.

It was found that water, as woll as mothanol and othanol, caused the relaxation time at $298^{\circ} \mathrm{K}$. to docrease. In all throe cases the curre of $\Delta H^{t}$ and $\Delta S^{t}$ versus vapor content passed at about $2.7 \%$ vapor content through a maximum, the height of which decreased in the order water, mothanol, and ethanol. This was correlated with the fact that the curre of cellulose density versus water content passes through a maximum at 
this very point. It was predicted that the corresponding density curres for mothanol and ethanol would run a similar course, the hoights decreasing in the samo order as for the $\Delta H^{t}$ and $\Delta S t$ curres. Thus it was shown that water, mothonol, and othanol have in collulose a plasticizing action comparable with that observed in other plasticized polymer systems. 
CLAIMS OF ORIGINAL WORK AND CONTRIBUTIONS TO KNOWLEDGE

1. Values of dielectric constant and dielectric loss factor were obtained in a dispersion region for a complex arrangement in the measuring condenser of a paper made of pure colluloso. Mossuroments wore performed over a range of frequency of 10 to $1000 \mathrm{Kc}$. and a range of temperature of -58 to $26^{\circ} \mathrm{C}$.

2. It was show by eloctrioal analysis that the position of the dispersion region thus obtained was not altered upon consideration of the data in terms of the paper itself.

3. From equations obtained as a result of this analysis calculations were made of the dielectric constant of the cellulose fibre at 1 Mo. and $20^{\circ} \mathrm{C}$. as a function of per cent adsorbed water, methanol, and ethenol, respectively.

4. In the same way the corresponding maximum dielectric loss factor was caloulated as a function of vapor content, the slopes of tho curres being considered as a moasure of the losses due to the hydroxyl groups in the adsorbod vapor.

5. From the maxima in the loss ourves relaxation times were ereluated. From plots of $\log T$ versus $1 / T$, calculations were made at $298^{\circ} \mathrm{K}$. of the free energy, enthalpy, and entropy of activation for di-loctric relaxation, these terms being considered as a function of rapor content. 


\section{BIBLIOGRAPHY}

1. Archer, W.L. Thesis, McGill University. 1949.

2. Argue. G.H., and Mass, O. Can. J. Research 12B, 564. 1935.

3. Ibid. 13B: 156. 1935.

4. Ibid. 13B: 160. 1935.

5. Ball, A.0. J. Chem. Soc. 570. 1930.

6. Brown, A.S., Iovin, P.M०, and Abrahamson, E.W. J. Chom Phys. 19. 1226. 1951.

7. Brown, D.F. Thesis, MoGill University. 1940.

8. Calkins, C.R. Tappi 33: 278. 1950.

9. Carter, W.C., Magat, M., Schneider, W.C., and Smyth, C.P. Trans. Faraday Soc. 421: 213. 1946.

10. Dakln, T.W., and Auxier, R.W. Ind. Eng. Chøm. 37, 268.1945.

11. Dartes, J.M., Miller, R.F., and Busse, W.F. J. Am. Chem. Soc. 63: 361. 1941.

12. Davis, R., Bridge, H.S., and Svirkeley, W.J. J. Am. Chem. Soc. 65: 857.1943.

13. Debye, P. Polar Molecules. Chemical Catalog Company, Inc., Now York. 1929.

14. De Luca, H.A. Thesis, McGill University. 1937.

15. De Luca, H.A., Compbell, W.B., and Marss, O. Can. J. Rosearch $16 \mathrm{~B}, 273.1938$.

16. Delevanti Jr., C., and Hansen, P.B. Paper Trade Journal (T.S.) 121: 241. 1945.

17. Frank, F.C. Trans. Far. Soc. 32: 1634. 1936.

18. Frank, F.C. Trans. Far. Soc. 42A: 19. 1946.

19. Frey-Wyssling, A., and Wuhrmann, K. Helv. chim. acta. 22, 981. 1939. 
20. Fröhlick, H. Thoory of Dielectrics. Oxford at the Clarondon Press. 1949.

21. Fuchino, Koiroku, and Okada, Noboru. Chem. Abst. 46: 1316g. 1952.

22. Fuoss, R.M. J. Am. Ghem. Soc. 63: 378. 1941.

23. Fuoss, R.M. J. Am. Chem. Soc. 63:2410. 1941.

24. Funt, B.L. Thesis, MoGill University. 1949.

25. Funt. B.I., and Mason, S.G. Can. J. Research. 28B: 182. 1950.

26. Goe. G. Trans. Faraday.Soc. L2A: 161. 1946.

27. Girard, P., and Abadie, P. Trans. Faraday Soc. 42A: 40.1946.

28. Glasstone, S., Eqidler, K.J., and Eyring, H. Theory of Rate Processes. MoGraw-Hill. 194I.

29. Guillien, R. Compt. rond. $217: 443$. 1943.

30. Homelly, E.J., Heston, W.M., Jr., and Smyth, C.P. J. Am. Chem. Soc. 70, 4102. 1948.

31. Honniger, P. Frøquonz 4: 167. 1950.

32. Hermans, P.H॰, and Woidinger, A. Bull. Soc. Chim. Belg. 57: 123. 1948 .

33. Hermans, P.H. Physics and Chemistry of Cellulose Fibres. Elsevior Publishing Co., Inc., Now York. 1949.

34. Hermans, F.H. Chem. Abstr. 45: 6835. 1951.

35. Hestion, W.Me, Jr., Hennelly, E.J., and Smyth, C.P. J. Am. Chem. Soc. $70: 4093.1948$.

36. Higuchi, Izumi, Chem. Abstr. 44: 7105, 1950.

37. Ibid., 45: 12. 1951.

38. Kauzmann, Tr. Rev. Mod. Phys. 14: 12. 1942.

39. King, G. Trans. Faraday Soc. 43:601. 1947.

40. Kronig, R. de L. Proc. Nat. Acad. 12: 488,608, 1926.

41. Laquer, H.L., and Smyth, C.P. J. Am. Chem. Soc. 70, 4097. 1948. 
42. Levi, D.L. Trans. Faraday Soc. 42A: 152. 1946.

43. Lund, Ho, and Bjerrum, J. Ber. 64: 210. 1931.

44. McIntosh, R., Riderl, E.K., and Snelgrove, J.A. Proc. Roy. Soc. 208A: 292. 1951.

45. Mensing, L., and Pauli, W. Physik. Zeit. 27:509. 1926.

46. Ott, Emil. Cellulose and Cellulose Derivatives. Interscience, New York. 1943.

47. Pelzer, H. Trans. Faraday Soc. 42A: 164. 1946.

48. Reddish, W. Trans. Faraday Soc. 46: 459. 1950.

49. Rollend, Marie-Thérèse, and Bernard, R. Compt. rend. 232, 1098. 1951.

50. Russell, J.K., Maass, O., and Campbell, W. Boyd. Can. J. Research. I5B: 13.1937.

51. Schallanach, A. Trans. Faraday Soc. 42A: 180. 1946.

52. Schallamach, A., and Thirion, P. Trans. Faraday Soc. 45: 605. 1949.

53. Scott, A.H., McPherson, A.T., and Curtis, H.L. Bur, Stand. J. Research. 11.173 .1933$.

54. Stark, K.H. Nature 166: 436. 1950.

55. Starke. Ann. Physik. 296: NF 60, 1897

56. Stearm, A.E., and Eyring, H. J. Chem. Phys. S: 113. 1937.

57. Stoops, W.N. J. Am. Chem. Soc. 56: 1480. 1934.

58. Sugden, S. J. Chem. Soc. 768, 1933.

59. Tausz, J., and Rurm, H. Koll. Beihefte 39:58. 1934.

60. Ton Vleck, J.H. Phys. Rev. 29: 727. 1927

61. Veith, H. Frequenz 3: 165. 1949.

62. Verseput, H.W. Tappi 34: 572. 1951.

63. Wahba. M. J. Phys, Coll. Chem. 52; 1197 . 1948.

64. Ibid. 54: 1148. 1950. 
65. Whiffen, D.H., and Thompson, H.W. Trans. Faraday Soc. 42A: 122. 1946.

66. White, A.H., Biggs, B.S., and Morgan, S.0. J. Am. Chem. Soc. 62: 16. 1940 . 